\title{
Ediacaran metazoan fossils with siliceous skeletons from the Digermulen Peninsula of Arctic Norway
}

\author{
Małgorzata Moczydłowska, ${ }^{1 *}$ (1) Benjamin P. Kear, ${ }^{2}$ Daniel Snitting, ${ }^{3}$ (1) Lei Liu, ${ }^{4}$ Peter Lazor, \\ and Jarosław Majka ${ }^{4,5}$
}

\footnotetext{
${ }^{1}$ Uppsala University, Department of Earth Sciences, Palaeobiology, Villavägen 16, SE 75236 Uppsala, Sweden, <malgo.vidal@pal.uu.se>

${ }^{2}$ Uppsala University, Museum of Evolution, Norbyvägen 16, SE - 75236 Uppsala, Sweden, <benjamin.kear@em.uu.se>

${ }^{3}$ Uppsala University, Evolutionary Biology Centre, Organismal Biology, Norbyvägen 18A, SE- 752 36, Uppsala, Sweden, <daniel. snitting@ebc.uu.se>

${ }^{4}$ Uppsala University, Department of Earth Sciences, Mineralogy, Petrology and Tectonics, Raman Lab, Villavägen 16, SE 75236 Uppsala, Sweden, <lei.liu@geo.uu.se>, <peter.lazor@geo.uu.se>, <jaroslaw.majka@geo.uu.se>

${ }^{5}$ AGH University of Science and Technology, Faculty of Geology, Geophysics and Environmental Protection, Mickiewicza 30,3059

Kraków, Poland
}

\begin{abstract}
In this study, a new assemblage of Ediacaran metazoan fossils is reported from the basal Stáhpogieddi Formation on the Digermulen Peninsula of Arctic Norway, including Anulitubus n. gen. Moczydłowska in Moczydłowska et al., Anulitubus formosus n. gen. n. sp. Moczydłowska in Moczydłowska et al., Coniculus n. gen. Moczydłowska in Moczydłowska et al., Coniculus elegantis n. gen. n. sp. Moczydłowska in Moczydłowska et al., Fistula n. gen. Moczydłowska in Moczydłowska et al., and Fistula crenulata n. gen. n. sp. Moczydłowska in Moczydłowska et al. The specimens are three-dimensionally preserved and include tubular and conical skeletons that are morphologically distinguished by their body-wall constructions, radial symmetry, polarity, segmentation, and annulation. The skeletons are interpreted to be biomineralized by primary silica based on computed micro-tomographic, petrographic, geochemical, and spectroscopic evidence of originally rigid body wall with layers of constant thicknesses, composed of opal, microcrystalline quartz, and an admixture of carbonaceous material, which differ from the host sediment mineralogy and do not show replacement or encrustation. The fossil-bearing interval immediately overlies strata of Gaskiers age and can be bracketed within 580-541 Ma, but it is estimated to be ca. $575 \mathrm{Ma}$ on the basis of averaged sedimentation rates and biostratigraphic correlations with Ediacaran biota found in up-section deposits of ca. 558-555 Ma. Future new findings of such fossils in different preservation modes and further multi-collector inductively coupled plasma mass spectrometry, which shows the silicon fractionation and traces its biogenic origin versus inorganic mineralization, may corroborate the interpretation of biogenic silicification of these earliest skeletal fossils.
\end{abstract}

UUID: https://zoobank.org/6bccada1-870e-47b0-b819-82685152ea54

\section{Introduction}

The early evolution of animals, or metazoans (Metazoa), can be traced back to the Ediacaran Period (635-541 Ma) based on the fossil record of macroscopic soft-bodied impressions, carbonaceous compressions, and subsequently mineralized and organically preserved organisms (Narbonne, 2005; Moczydłowska et al., 2014; Wan et al., 2016; Xiao et al., 2016; Schiffbauer et al., 2020). However, a more ancient metazoan origination event has been inferred using molecular clocks, which suggests emergence times ranging from between 833-650 Ma (dos Reis et al., 2015), to a more specific point estimate of up to $780 \mathrm{Ma}$ (Erwin et al., 2011). The affinities of the various Ediacaran metazoan taxa are likewise unresolved and are often contested

*Corresponding author because of their unusual morphologies and lack of unambiguous diagnostic features in comparison to modern phyla; these have resulted in assorted identifications including sponges, placozoans, cnidarians, lophophorates, and putative bilaterian metazoans (Narbonne, 2005; Fedonkin et al., 2007a, b; Xiao and Laflamme, 2009; Sperling and Vinther, 2010; Erwin et al., 2011; Sperling et al., 2011; Zhuravlev et al., 2015; Hoyal Cuthill and Han, 2018; Wood et al., 2019; Schiffbauer et al., 2020; Shore et al., 2020).

The preserved remains of Ediacaran metazoans seem to represent body tissues that were largely composed of soft organic matter (Moczydłowska et al., 2014; Narbonne et al., 2014; Yin et al., 2015; Wan et al., 2016; Bobrovskiy et al., 2019; Schiffbauer et al., 2020), although calcified skeletons had appeared by ca. 550 Ma (Germs, 1972; Grant, 1990; Grotzinger et al., 2000; Wood et al., 2002, 2019; but see Schiffbauer et al., 2020, and Yang et al., 2020). The onset of metazoan 
mineralization is a precursor to the independent acquisition of biomineralized skeletons and of different mineralogies by multiple metazoan clades, an important feature of the Cambrian Explosion (541-485 Ma; Erwin et al., 2011; Erwin and Valentine, 2013; Murdock, 2020).

Here we report an assemblage of three-dimensionally (3-D) preserved macroscopic tubular and conical fossils from marine siliciclastic strata of Ediacaran age on the Digermulen Peninsula of Arctic Norway. These specimens represent three distinct morphotypes, which we recognize as distinct taxa, and are thus interpreted as components of a coeval assemblage that is stratigraphically restricted to the basal succession of the Stáhpogieddi Formation. This interval lies $40-42 \mathrm{~m}$ above the Mortensneset Diamictite-an uppermost marker of the Varangerian glaciations in Scandinavia (Føyn, 1985; Nystuen, 1985) and correlated with the regional Ediacaran Gaskiers glaciation at ca. 580 Ma (Halverson et al., 2005, 2010; Rice et al., 2011; Pu et al., 2016). The affinities of the new taxa remain uncertain, but collectively all features suggest eumetazoans. We apply a range of microscopic, computed micro-tomographic, petrographic, and geochemical techniques to determine their morphology and mineralogy. This reveals evidence of primary siliceous biomineralization, which to our knowledge, constitutes the earliest examples of silica-based animal skeletons yet documented from the fossil record. The global stratigraphic ranges of the Ediacaran impression fossils, including Dickinsonia Sprigg, 1947, Swartpuntia Narbonne et al., 1997, Hiemalora Fedonkin, 1982, and Aspidella Billings, 1872, and 3-D modular Palaeopascichnus Palij, 1976 occurring in the Stáhpogieddi Formation (Farmer et al., 1992; Högström et al., 2013, 2017; Høyberget et al., 2017; McIlroy and Brasier, 2017; Jensen et al., 2018; additional new data on Dickinsonia and Swartpuntia per A. Högström, personal communication, 2018; Fig. 2) are compiled and the sedimentary continuity of this formation is discussed with the purpose of estimating the age of the new taxa.

\section{Geological setting, stratigraphy, and age}

Tectonic setting.-The Stáhpogieddi Formation is well exposed across the Digermulen Peninsula in far northeastern Finnmark, Arctic Norway. Structurally, the region forms part of the Gaissa Thrust Belt (or Gaissa Nappe Complex) within the Lower Allochthon of the eastern Scandinavian Caledonides. The Digermulen Peninsula is in a continuous transition with the parautochtnonous and autochthonous areas around Tanafjorden and on the Varanger Peninsula (Gee and Sturt, 1985; Gayer et al., 1987; Siedlecka et al., 2006; Rice, 2014; Fig. 1).

Geologically, it has been subjected to limited tectonic, diagenetic, and thermal modifications in comparison to the highly metamorphosed nappes in the central Caledonides, which have a complex history of folding and décollement (Roberts and Gee, 1985; Gayer et al., 1987; Dallmeyer et al., 1989; Roberts, 2003; Rice, 2014; Meinhold et al., 2019a). The Gaissa Thrust Belt has experienced low angle thrusting over a relatively short distance (Rice, 2014) and is sequentially sub-divided into the Vadsø, Ekkerøya (elsewhere considered a formationlevel unit of the Vads $\varnothing$ Group; Føyn, 1985), Tanafjorden, Vestertana, and Digermulen groups, with a total succession thickness of $\sim 5 \mathrm{~km}$.

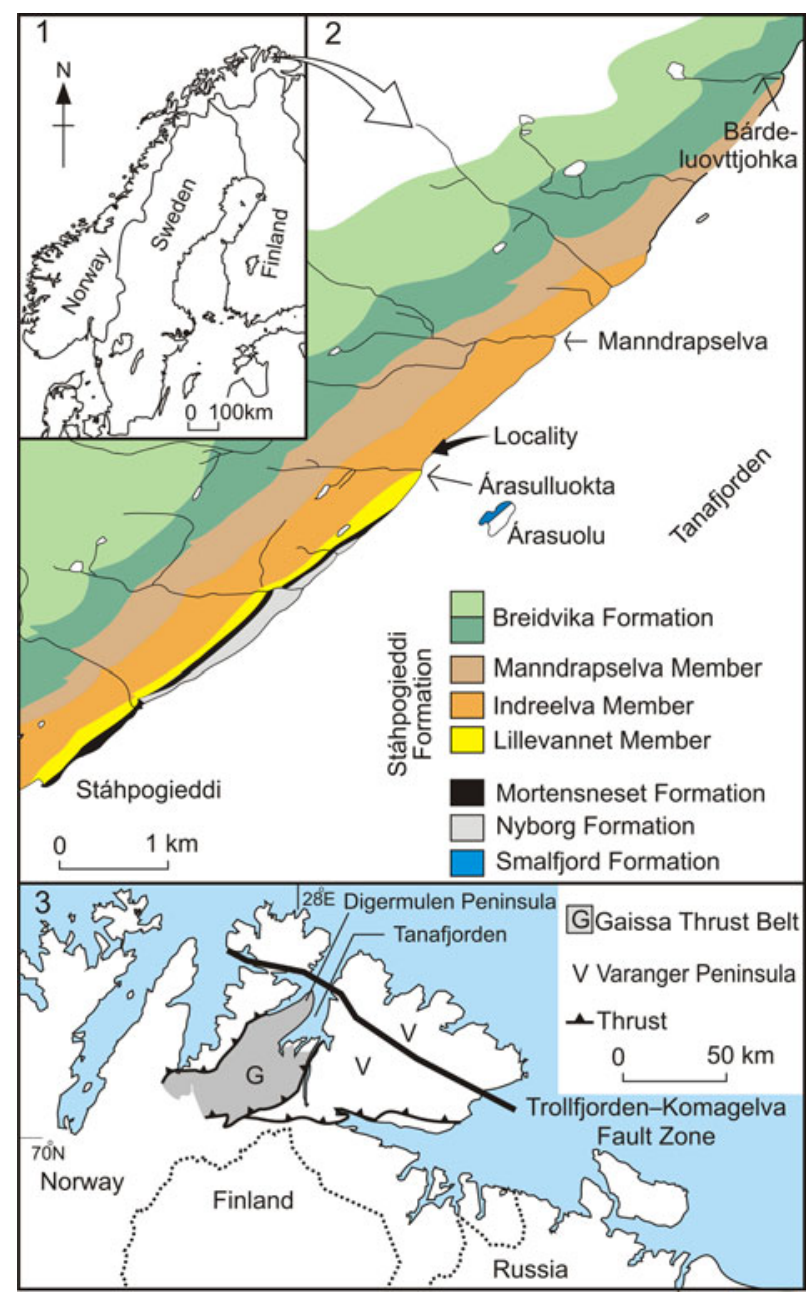

Figure 1. Sketch-map of Scandinavia with studied area marked in northern Norway by arrow in (1), pointing to geological map of the Ediacaran-Cambrian strata on the Digermulen Peninsula coastal outcrop in (2), showing the new fossils locality. The outline of the Varanger and Digermulen peninsulas and the Tanafjorden area is in (3) with Gaissa Thrust Belt shaded gray.

The Vestertana Group, including the studied Stáhpogieddi Formation (Fig. 2), was deposited in a foreland basin under shallow marine to deep outer shelf sedimentary conditions on a passive continental margin (Roberts and Siedlecka, 2002; Rice et al., 2012; Rice, 2014; W. Zhang et al., 2015). This basin developed along the western Baltica paleocontinent at $\sim 50^{\circ} \mathrm{S}$ (orientation at the time; Torsvik and Cocks, 2017).

Stratigraphic information.-The Vestertana Group extends stratigraphically from the upper Cryogenian Smalfjord Formation, which incorporates mostly terrestrial fluvioglacial diamictite and glaciomarine sediments correlated with the Marinoan Glaciation at 635.5 $\pm 0.6 \mathrm{Ma}$ (Edwards, 1984; Gayer and Rice, 1989; Condon et al., 2005; Rice et al., 2011, 2012; see Bechstädt et al., 2018 for a recent review; further referred to $635 \mathrm{Ma}$ ) to the Breidvika Formation of the lower Cambrian Terreneuvian Series (Reading and Walker, 1966; Farmer et al., 1992; Högström et al., 2013; Jensen et al., 2018; Fig. 2). The age range of the Vestertana Group is chemo- and biochronologically constrained to 635-521 Ma (Rice et al., 
VARANGER AND DIGERMULEN PENINSULAS

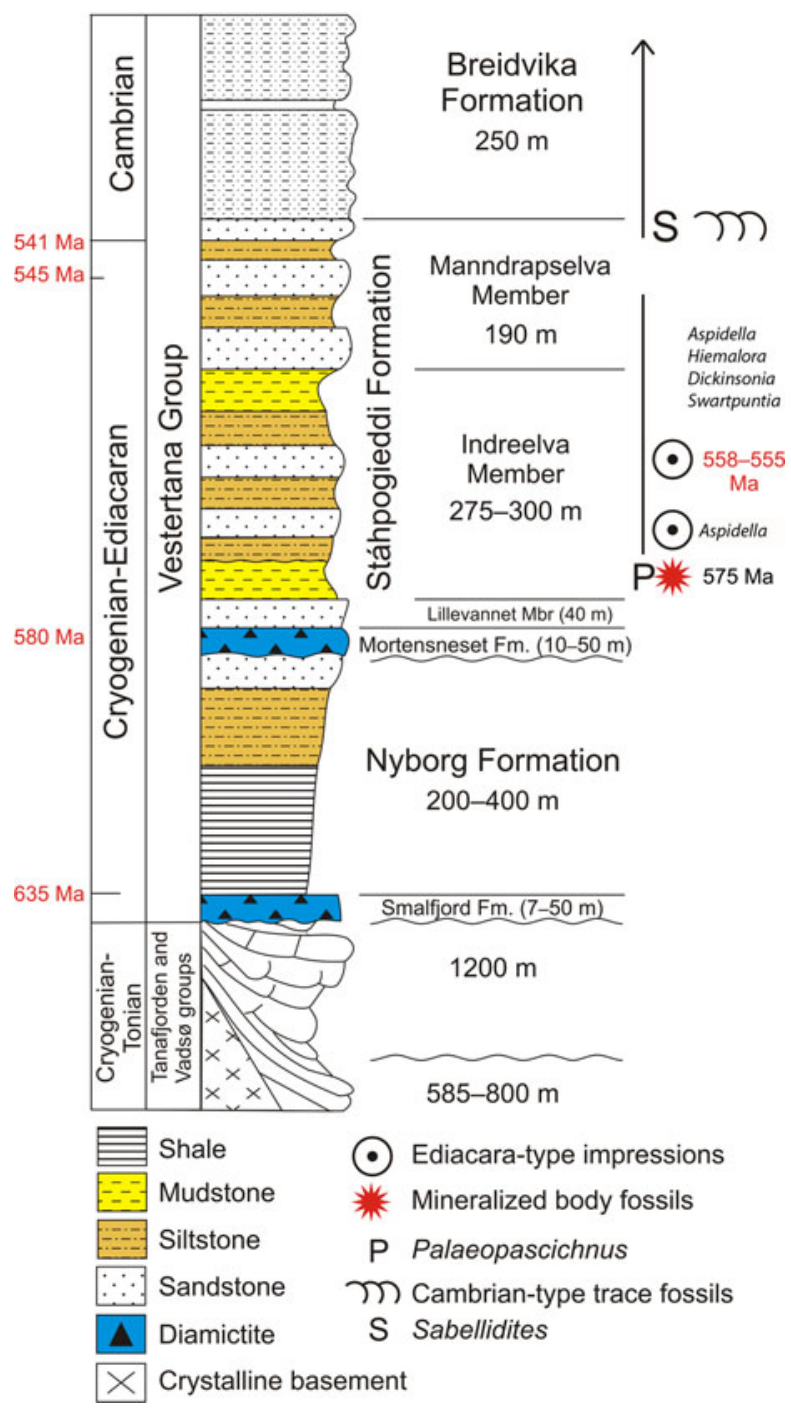

Figure 2. Ediacaran sedimentary succession on the Digermulen Peninsula showing the stratigraphic distribution of fossils and new mineralized body fossils. In the left column, the isotopic ages of the Marinoan and Gaskiers glaciations at $635 \mathrm{Ma}$ and $580 \mathrm{Ma}$, respectively, and their time-equivalent diamictites are marked; the base of the Cambrian at $541 \mathrm{Ma}$, and the age of the topmost Manndrapselva Member at $545 \mathrm{Ma}$ are all published data (Peng et al., 2012; Zhang et al., 2015; Pu et al., 2016; Xiao et al., 2016). Note the Cryogenian age of the Smalfjord Formation at the base of the succession. In the right column, the age of the Ediacara-type impression fossils is chronostratigraphically recognized from their global ranges at 558-555 Ma and at the lower occurrence of only Aspidella (referenced in the text). The age of new mineralized body fossils is interpolated herein at ca. 575 Ma.

2011; Jensen et al., 2018). The Vestertana Group sequentially comprises the Smalfjord, Nyborg, Mortensneset, Stáhpogieddi, and Breidvika formations and is $1120-2025 \mathrm{~m}$ thick, depending on the lateral facies distribution across the depositional basin (Reading, 1965; Reading and Walker, 1966; Banks et al., 1971; Banks, 1973; Edwards, 1984; Føyn, 1985; Rice et al., 2012). The Mortensneset Formation contains an upper glaciomarine diamictite correlated with the Gaskiers Glaciation at $580 \mathrm{Ma}$ (Halverson et al., 2005; Halverson and Shields-Zhou, 2011; Rice et al., 2011; Pu et al., 2016; see also discussion by Jensen et al., 2018). The two glacigenic formations were previously attributed to the Lower and Upper Tillites of the late Proterozoic Varanger Ice Age, respectively (Føyn, 1985; Nystuen, 1985).

The post-glacial Stáhpogieddi and Breidvika formations are marine siliciclastic successions that preserve age-diagnostic fossils (Farmer et al., 1992; Högström et al., 2013; McIlroy and Brasier, 2017; Jensen et al., 2018) and constitute a conformable succession with the underlying Mortensneset Formation (Reading, 1965; Reading and Walker, 1966; Banks et al., 1971; Banks, 1973; Edwards, 1984; Føyn, 1985; Gayer and Rice, 1989; Farmer et al., 1992; Rice et al., 2012; Högström et al., 2013; Rice, 2014; Jensen et al., 2018). Regional unconformities have been recognized at the bases of the Smalfjord and Mortensneset diamictites (Edwards, 1984; Rice et al., 2012; see compilation by Rice, 2014; Fig. 2), and thus have implications for determining the relative age of the Stáhpogieddi Formation.

The Stáhpogieddi Formation is a 530-m-thick succession of alternating mudstones, siltstones, and sandstones, with a few thin calcified siliciclastic beds in the uppermost part, and is undeformed, other than being tilted and dipped at $19-28^{\circ} \mathrm{W}$, cleaved, and affected by diagenesis and low-grade thermal overprinting (Dallmeyer et al., 1989; Farmer et al., 1992; Meinhold et al., 2019a, b; Fig. 2). The formation has been subdivided into the Lillevannet, Indreelva, and Manndrapselva members, which reflect transgressive-regressive parasequences within a continuous succession; shallowing events mark the sedimentary parasequences, including two distinct upward-coarsening turbidite sandstone intervals occurring within the Indreelva Member and three within the Manndrapselva Member (Reading, 1965; Reading and Walker, 1966; Banks et al., 1971; Banks, 1973; Siedlecka, 1985; Farmer et al., 1992; Rice, et al., 2012; Högström et al., 2013; Jensen et al., 2018). The boundaries between the members of the Stáhpogieddi Formation are gradual or at sharp lithologic contacts but conformable.

The basalmost Lillevannet Member is a 40-m-thick quartzitic sandstone with cross-bedding and ripple cross-lamination. It is also interbedded with mudstone and occasional conglomerate layers that reflect a transition from fluvial to shallow marine, sub-tidal environments (Reading and Walker, 1966; Banks et al., 1971; Edwards, 1984; Rice et al., 2012).

The overlying Indreelva Member, which has yielded the new fossils, is up to 300-m-thick succession and consists of red and green, thin-bedded mudstone with subsequent alternating siltstone, mudstone, and sandstone beds (Fig. 2). A rapid transition from sub-tidal mudstone into a deeper, sub-wave-base facies occurs in the basal portion of the member. The succession was deposited in quiet water environments on an offshore deeper shelf (characterized by mudstone, siltstone) with two regressive intervals (sandstone) tracking a gradual change into shallow marine shelf conditions (Reading, 1965; Banks et al., 1971; Banks 1973; Edwards, 1984; Rice et al., 2012).

The uppermost Manndrapselva Member is a 190-m-thick succession of alternating coarse-grained quartzitic sandstone interbedded with greywacke and thin-bedded siltstone. It incorporates three shallowing-upward parasequences consisting of fine-grained distal to proximal turbidite sediments deposited on an outer marine shelf; the quartzitic sandstone intervals reflect shallower marine conditions (Reading, 1965; Reading 
and Walker, 1966; Banks et al., 1971; Högström et al., 2013; Jensen et al., 2018).

The only occurrence of carbonate sediments within the Stáhpogieddi Formation includes a series of discontinuous calcified siliciclastic beds up to $15 \mathrm{~cm}$ thick. These are randomly distributed as calcareous lenses and concretions over a 23-m-thick interval of the upper Manndrapselva Member, and are observable over a limited outcrop on the Digermulen Peninsula (Meinhold et al., 2019b). These upper Manndrapselva Member siliciclastic sediments formed during the late Ediacaran and were locally early diagenetically calcified and altered into concretions through the late Cambrian-Ordovician time (Meinhold et al., 2019b). The stratigraphic interval bearing these carbonates lies $40 \mathrm{~m}$ below the base of the Cambrian recognized in the succession, is of latest Ediacaran age and a rather insignificant sedimentary component within the 530-m-thick siliciclastic Stáhpogieddi Formation The upper boundary of the Stáhpogieddi Formation with the succeeding Breidvika Formation is lithologically abrupt but without any depositional break (Jensen et al., 2018).

The Stáhpogieddi Formation contains the diagnostic Cambrian-type trace fossils and organic tubular metazoan Sabellidites Yanishevsky, 1926 in its uppermost part, the Ediacara-type impression fossils in the middle, the new body fossils in the lowermost part, and casts and molds of modular Palaeopascichnus macrofossils extending throughout the formation (Farmer et al., 1992; Högström et al., 2013; Mcllroy and Brasier, 2017; Jensen et al., 2018). The Ediacaran-Cambrian boundary is recognized in the uppermost Manndrapselva Member (Högström et al., 2013; McIlroy and Brasier, 2017; Jensen et al., 2018; Fig. 2).

Sedimentary continuity within the Stáhpogieddi Formation.Regionally, in a scale of the marine depositional basin extending across the Digermulen and Varanger peninsulas, the entire succession, including the Mortnesneset Diamictite Formation, the Lillevannet Member, and the succeeding members of Stáhpogieddi Formation, is sedimentologically continuous. This has been examined by numerous studies and synthesized by Rice et al. (2012) and Rice (2014), see also discussion by Jensen et al. (2018). On the Digermulen Peninsula, the contact between the Mortensneset Formation and the Lillevannet Member is lithologically abrupt between diamictite and mudstone or sandstone, but without erosion and is conformable (Reading and Walker, 1966; Edwards, 1984; Gayer and Rice, 1989; Rice et al., 2011, 2012; Rice, 2014; Jensen et al., 2018). This contact was suggested to be a sharp erosional unconformity (McIlroy and Brasier, 2017, p. 355), but without indicating any sedimentary structures for erosion. The conglomerate layers in the middle of the Lillevannet Member, which occur only on the Varanger Peninsula, show a shallowing, regressive interval with channels cutting sub-surface and fluvial influx from the nearby continental margin of a high relief into marine basin, but these layers do not extend farther into shelf on the Digermulen Peninsula (Banks et al., 1971; Edwards, 1984). These conglomerates are not considered to represent an erosional unconformity involving time hiatus, but rather show lateral facies distribution within the Lillevannet Member.
McIlroy and Brasier (2017, p. 353) suggested that a significant depositional hiatus occurred within either the Lillevannet or Indereelva members based on their comparison of the 530-m-thick upper Ediacaran (ca. 580-541 Ma) succession of the Stáhpogieddi Formation with the 2500 m thick succession between the Gaskiers Formation and the Cambrian GSSP horizon in southeastern Newfoundland (McIlroy and Brasier, 2017 cited as Dalrymple et al., 2006, but Ichaso et al., 2007 is the correct citation for this data) corresponding to the same time interval. However, this is misleading because the Newfoundland strata (including the Conception and St. John's groups in west Conception Bay, the Avalon Zone) comprise deep-water, siliciclastic-volcanoclastic turbidites, contourites, and volcanic ash beds deposited in marine slope-to-basin settings. Such forearc, pull-apart depositional basins within the tectonic subduction zone of a spreading center (Ichaso et al., 2007) typically experience very fast sedimentation rates (Stow, 1986; Leeder, 1994). This clearly conflicts with the Stáhpogieddi Formation, which was otherwise deposited on a passive margin, and therefore is substantially thinner, but continuous with no demonstrable sedimentological unconformities (Farmer et al., 1992; Rice et al., 2012; Rice, 2014; Jensen et al., 2018; Fig. 2). We therefore favor a more feasible depositional comparison with the 500-m-thick upper Ediacaran succession in the Adelaide Rift Complex in South Australia; this fine-grained siliciclastic succession comprises minor dolomites and accumulated on carbonate shelf to delta front with some basinal sedimentation (Grey, 2005 , p. 38, fig. 13) and has been bracketed at 580-541 Ma based on isotopic dating of the Acraman ejecta layer versus the Ediacaran-Cambrian boundary (Grey, 2005, p. 54).

The Ediacaran fossil ranges and chronostratigraphy.-The Ediacaran soft-bodied macroscopic impression taxa (some also known from 3-D casts and molds in other occurrences), including Dickinsonia, Swartpuntia, Hiemalora, and Aspidella, and 3-D preserved Palaeopascichnus are recorded in the Stáhpogieddi Formation (Fig. 2). Their first appearance datum (FAD), last appearance datum (LAD), and stratigraphic ranges are established from global records and used for our estimation of the age of the assemblage containing them on the Digermulen Peninsula. Furthermore, this age provides a biochronologic time frame for the new fossils, which underlie $\sim 130 \mathrm{~m}$ below in the rock succession (Fig. 2). The FADs and LADs of individual taxa may be approximately recognized from isotopic dates of the rock levels that are close to their records, and we follow those well-dated ranges.

Biostratigraphic range of Dickinsonia.-The impression fossil total grouping of Dickinsoniomorpha has been constrained to either 559-550 Ma (Fedonkin and Vickers-Rich, 2007; Grazhdankin, 2014) or 556-541 Ma time intervals (Narbonne et al., 2012; Xiao et al., 2016). The nominal genus Dickinsonia ranges between 558-555 Ma (Wood et al., 2019), with the FAD and LAD following isotopic calibrations from the White Sea assemblage in Russia (Martin et al., 2000; Fedonkin and Vickers-Rich, 2007).

Biostratigraphic range of Swartpuntia.-The monotypic genus Swartpuntia is isotopically dated to between $545.1 \pm 1$ Ma and $543.3 \pm 1 \mathrm{Ma}$ and up to $539.4 \pm 1 \mathrm{Ma}$ or $538 \pm 1 \mathrm{Ma}$ in the Nama Group of Namibia (Narbonne et al., 1997; Vickers- 
Rich, 2007), and recently updated to $538.99 \pm 0.21$ Ma (Linnemann et al., 2019). In the White Sea assemblage, Swartpuntia germsi Narbonne, Saylor, and Grotzinger, 1997 is recorded in the middle of the Verkhov Formation, which is isotopically dated to between $558.3 \pm 1 \mathrm{Ma}$ and $555.3 \pm 0.3 \mathrm{Ma}$ (Martin et al., 2000; Fedonkin and Vickers-Rich, 2007). Swartpuntia cf. $S$. germsi occurs together with the cloudiniids, which range at 550-541 Ma, in the Wood Canyon Formation of Nevada, USA, and shortly below the appearance of the Cambrian Treptichnus Miller, 1889 trace fossil, thus confirming its uppermost Ediacaran extension (Hagadorn and Waggoner, 2000) as known in Namibia. The Swartpuntia-like molds similarly occur alongside Treptichnus in the lowermost Cambrian Uratanna Formation in the Flinders Ranges of South Australia (Wood et al., 2019) and support a LAD of the genus that accords with the more reliably dated Nama assemblage (Linnemann et al., 2019). The range of Swartpuntia is 558-539 Ma and its FAD coincides with that of Dickinsonia (558-555 Ma).

Biostratigraphic range of Hiemalora.-The range of Hiemalora is within the time interval of 565-550 Ma (Hofmann et al., 2008; Chen et al., 2014; Grazhdankin, 2014). The LAD is within the Shibantan Member of the Dengying Formation in China, whose deposition is bracketed to between 551-541 Ma, with a precisely dated horizon of the formation basal age at $551.09 \pm 1.02 \mathrm{Ma}$ (Schmitz, 2012). Chen et al. (2014) alternatively listed a LAD of $550 \mathrm{Ma}$. The range of Hiemalora could be substantially wider, if one would accept this taxon to be synonymous with Aspidella and both to represent the preservation states of holdfasts of frondose taxa like Charniodiscus Ford, 1958 rather than discrete species (Burzynski and Narbonne, 2015; Burzynski et al., 2017a, b). This synonymy has not yet been supported by the record of Aspidella and Hiemalora being attached to specimens of the same frondose taxon. On the other hand, the connection between Hiemalora as being the holdfast of Primocandelabrum hiemaloranum Hofmann, O'Brien, and King, 2008 is documented in a fossil specimen preserving those two taxa together (Hofmann et al., 2008). Additionally, Primocandelabrum Hofmann et al., 2008 is not attributed to any recognized Ediacaran clade, whereas Charniodiscus is associated with Arboreomorphs (Burzynski and Narbonne, 2015), suggesting that Hiemalora may not be the preservation state of Aspidella.

Biostratigraphic range of Aspidella.-The type species Aspidella terranovica Billings, 1872 has a global stratigraphic range of 579-550 Ma (Grazhdankin, 2014), with slightly narrower of 571-560 Ma range in Avalon Zone type area of SE Newfoundland (Liu et al., 2015; Pu et al., 2016), or 580-560 $\mathrm{Ma}$ in the Mackenzie Mountains of NW Canada (Burzynski et al., 2017a). Wood et al. (2019) listed Aspidella within a simplified category of "discs" at 571-540 Ma, but without including Hiemalora and seemingly without its older part in NW Canada and globally. Two specimens of Aspidella from the Mackenzie Mountains among numerous "discs" are reported from Cryogenian strata and suggest extension this taxon's stratigraphic range by ca. 80 Ma (Hofmann et al., 1990; Burzynski et al., 2017a). Regardless of the Cryogenian record and the late Ediacaran acme range of Aspidella at ca. 571-540 Ma, the taxon is less stratigraphically significant. We treat the two taxa, Aspidella and Hiemalora, as individual genera and their ranges are only partially overlapping at 565-550 Ma (i.e., coinciding with the range of Hiemalora).

Biostratigraphic range of Palaeopascichnus.-This modular fossil, also broadly treated within the group of palaeopascichnids, has been taxonomically synonymized with several taxa and its range suggested to span the entire Ediacaran Period (Kolesnikov et al., 2018). The junior synonym Orbisiana Sokolov, 1976, emend. Wan et al., 2014 occurs in the lowermost Ediacaran Lantian Formation of South China, which is estimated at 635-590 Ma (Yuan et al., 2011; Wan et al., 2014, 2016; Wang et al., 2017; Kolesnikov et al., 2018), but with re-evaluation to ca. 620-580 Ma based on correlation with the member II of the Doushantuo Formation (Yuan et al., 2011; Wang et al., 2017), for which the cited age is estimated (Liu and Moczydłowska, 2019). Palaeopascichnus has been identified in Baltica and Avalonia at 565-541 Ma (Grazhdankin and Maslov, 2009, 2015; Jensen et al., 2018) and in Australia at 560 Ma (Haines, 2000; Bowring et al., 2007). The overall global range of paleopascichnids is estimated at 580-540 Ma (Grazhdankin, 2014). We follow the range of Palaeopascichnus to span most of the Ediacaran Period, ca. 620-540 Ma (not all), and the taxon has limited stratigraphic significance.

Based on the current recognition of stratigraphic ranges in isotopically dated sedimentary intervals containing the fossils, the overlapping ranges of Aspidella, Hiemalora, Dickinsonia, and Swartpuntia at 558-555 Ma provide the closest available age that is inferred for the strata recording these taxa in the Stáhpogieddi Formation (Fig. 2).

Age of the Stáhpogieddi Formation and recorded fossils.-The base of the Stáhpogieddi Formation correlates with the top of the Mortensneset Formation diamictite at $580 \mathrm{Ma}$ (Halverson et al., 2005; Halverson and Shields-Zhou, 2011; Rice et al., 2011, 2012; Pu et al., 2016). Detrital zircon grains of Baltican provenance recovered from the medium-grained turbiditic sandstone in the upper Manndrapselva Member of the Tanafjorden area, which extends laterally to the Digermulen Peninsula, have provided ages of $542.1 \pm 2.8,542.4 \pm 4.8$ and $544.9 \pm 5.1 \mathrm{Ma}$ (W. Zhang et al., 2015). The maximum age of this sediment interval is thus $545 \mathrm{Ma}$ (W. Zhang et al., 2015; Fig. 2), which concurs with the $541 \mathrm{Ma}$ age estimate based on trace fossils from the uppermost horizons of the Manndrapselva Member (Högström et al., 2013; Jensen et al., 2018). These ages bracket the Stáhpogieddi Formation to between 580-541 Ma and slightly younger where it extends into the Cambrian (Jensen et al., 2018; Fig. 2). The uppermost Manndrapselva Member records the first appearance of Treptichnus pedum (Seilacher, 1955) and other Cambrian-type trace fossils (Jensen, 1997; Högström et al., 2013; McIlroy and Brasier, 2017; Jensen et al., 2018). Treptichnus pedum is also the index taxon for the base of the Cambrian System at the GSSP in Newfoundland (Narbonne et al., 1987; Brasier et al., 1994; Landing, 1994). U-Pb dates from the Ediacaran-Cambrian transitional strata (Grotzinger et al., 1995; Bowring and Schmitz, 2003; Bowring et al., 2007) have refined the lower Cambrian boundary to $541 \pm 0.63 \mathrm{Ma}$ (Peng et al., 2012; further referred to $541 \mathrm{Ma}$; Fig. 2) or possibly to ca. 539 Ma (Linnemann et al., 2019). The latter age of the stratigraphic level suggested for the Ediacaran-Cambrian 
boundary in the Nama Group of Namibia (in a composite section) is within $538.99 \pm 0.21 \mathrm{Ma}$ to $538.58 \pm 0.19 \mathrm{Ma}$ (Linnemann et al., 2019; further referred to $539 \mathrm{Ma}$ ). Before the new age may be accepted by the International Commission of Stratigraphy (ICS), we will use the age at $541 \mathrm{Ma}$ for the lower Cambrian boundary and the age at $539 \mathrm{Ma}$ for the ranges of certain fossil taxa recognized in Namibia (Linnemann et al., 2019) and extending from the Ediacaran.

Classic Ediacaran impression fossils, including Aspidella, Hiemalora, Dickinsonia, and Swartpuntia, all occur in the middle Indreelva Member of the Stáhpogieddi Formation (Farmer et al., 1992; Högström et al., 2013, 2017; Høyberget et al., 2017; new identification of Dickinsonia and Swartpuntia; Fig. 2) and provide a demonstrable age range of 558-555 Ma (Fig. 2), and certainly not younger relying on the LAD of Dickinsonia. The FAD of Dickinsonia and Swartpuntia, which is isotopically dated (Martin et al., 2000; Fedonkin and Vickers-Rich, 2007), constrains the maximum age. The time interval 558-555 $\mathrm{Ma}$ is the biochronologically estimated age of this stratigraphic horizon in the Stáhpogieddi Formation The lowermost occurrence of Aspidella in the succession (Högström et al., 2017; Høyberget et al., 2017) may be close to this taxon acme occurrence known from $571 \mathrm{Ma}$ (Wood et al., 2019), and is shortly above the new fossils (Fig. 2).

Our new Indreelva Member assemblage co-occurs with Palaeopascichnus, which prompted a specific age correlation for this interval at ca. $565 \mathrm{Ma}$ (Jensen et al., 2018). As mentioned, this taxon has wide stratigraphic range spanning 620-540 Ma and we decline from using this taxon for age determination in the Stáhpogieddi Formation.

The age of the new fossil assemblage may also be estimated from its relative stratigraphic position within the Stáhpogieddi Formation and calculated rate of deposition within the succession. Examples and arguments exist that the rates of deposition may be very variable and change in marine environments. Variables that are considered in estimating the rate of deposition include record fidelity, complex and incomplete nature of stratigraphic record owing to changing dynamics of the depositional system, variation in rate of deposition for elements in the basin, time and length scales, and stochastic processes ("noise") (Tipper, 2016; Davies et al., 2019; Holbrook and Miall, 2020; Straub et al., 2020). However, in long timescales, the rates of deposition are statistically buffered over periodicity (Straub et al., 2020) and cyclic variability sums produce the average rate of deposition, which can be plausibly estimated from measured parameters of sediment thickness over the time span of the section (Holbrook and Miall, 2020; Straub et al., 2020). The accuracy of average rates of deposition depends on the vertical thickness and longer durations of time (Holbrook and Miall, 2020). The measured rates of deposition are balanced among states of deposition, erosion, and stasis (Davies et al., 2019) and are normalized for longer measurement duration (Straub et al., 2020). Despite the limitations of the incomplete records and variation of rates of deposition, the estimation of rate of deposition is worthwhile and possible (Tipper, 2016).

Depositional environments of the Stáhpogieddi Formation in the lowland basin were relatively stable on the passive continental margin, and cyclic shallowing and deepening events due to sea-level changes were of low amplitudes within shelf settings without tectonic disturbance or erosional unconformities (Gayer and Rice, 1989; Rice et al., 2012; Rice, 2014). This formation consists of transgressive-regressive parasequences, in which the rate of deposition between alternating units of mudstone, siltstone, and sandstone certainly varied in small-scale intervals. However, in a substantial thickness $(530 \mathrm{~m})$ of sedimentologically continuous succession it is rather uniform. In a cyclic repetition of fine- to coarser-grained siliciclastic rocks, the average rate of deposition is normalized and similar throughout the succession. Plausibly therefore, the long deposition time within $39 \mathrm{Ma}$ (580-541 Ma and slightly younger; Fig. 2), together with its continuous sedimentation at similar average rate of $13.59 \mathrm{~m} / \mathrm{Ma}$, allows the interpolation of the ages within various portions of the formation. Most likely, the basal Indreelva Member, containing the new body fossils and overlying $40-42 \mathrm{~m}$ above the Mortensneset Formation, can be estimated at as little as $3 \mathrm{Ma}$, and rounded to as much as 5 Ma younger than the base of the formation assuming a degree of error (Fig. 2). Notably, this estimated ca. 575 Ma age limit is consistent with the FAD for typical Ediacaratype impression fossils in the middle Indreelva Member, which occur $\sim 130 \mathrm{~m}$ above, and their overlapping ranges at 558-555 Ma. Calculating independently from the rate of deposition in the narrower sediment interval limited by the age-controlled horizons between 558-555 Ma and $580 \mathrm{Ma}$ (Fig. 2), this $172 \mathrm{~m}$ of continuously deposited sediments in 22-25 Ma allow estimation of the time horizon of new fossils to be 5.46-6.10 Ma younger than $580 \mathrm{Ma}$. This conforms to the age estimated from the entire succession at ca. $575 \mathrm{Ma}$. Therefore, the average rate of deposition may be considered here as reliable.

\section{Materials and methods}

Twenty-two individual fossil specimens were collected from natural exposures along bedding plains in mudstone of the lowermost Indreelva Member in the Stáhpogieddi Formation (Fig. 2). The host sediment laminae bent plastically around the skeletons, which were slightly distorted by tectonic compression but retained hollow lumen or were mostly post-mortem infilled with the host sediment. Three different morphotypes are recognized at the rank of monotypic genera (of single species) and taxonomically described.

The fossils were studied under a reflected light microscope (RLM), a transmitted and polarized light microscope (PLM), an environmental scanning-transmission electron microscope (STEM) equipped with energy-dispersive X-ray detector for energy dispersive spectroscopy (STEM EDS), and a field emission electron probe microanalyzer (EMP) also equipped with EDS detector. Three-dimensional rendering and visualization of internal structures was also undertaken using a Nikon H225 ST Micro-Computed Tomography (CT) at the University of Oslo (Supplementary Data). Petrographic thin-sectioning was also carried out with geochemical and acid tests, as well as STEM EDS, EMP EDS, and Laser-Raman spectroscopy to determine mineralization (Supplementary Data). The mineral composition of the surrounding mudstone matrix was examined using Laser-Raman spectroscopy and X-ray diffraction (XRD; Supplementary Data). 
Anulitubus
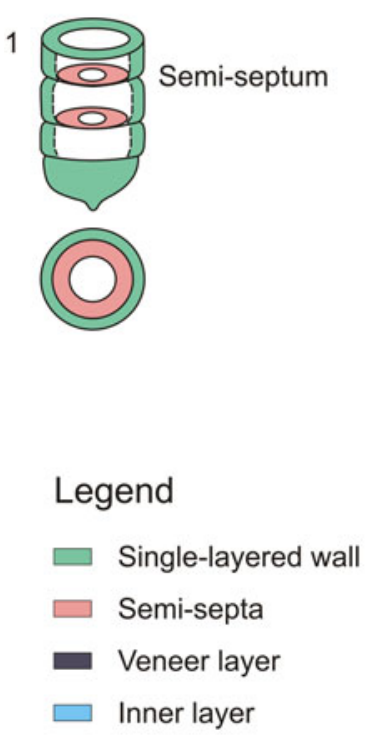

2

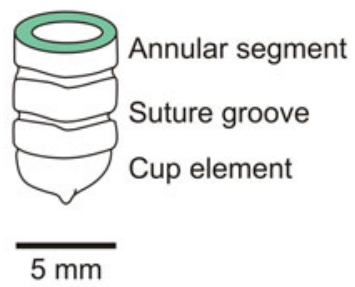

Coniculus

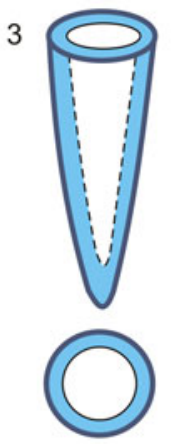

Fistula

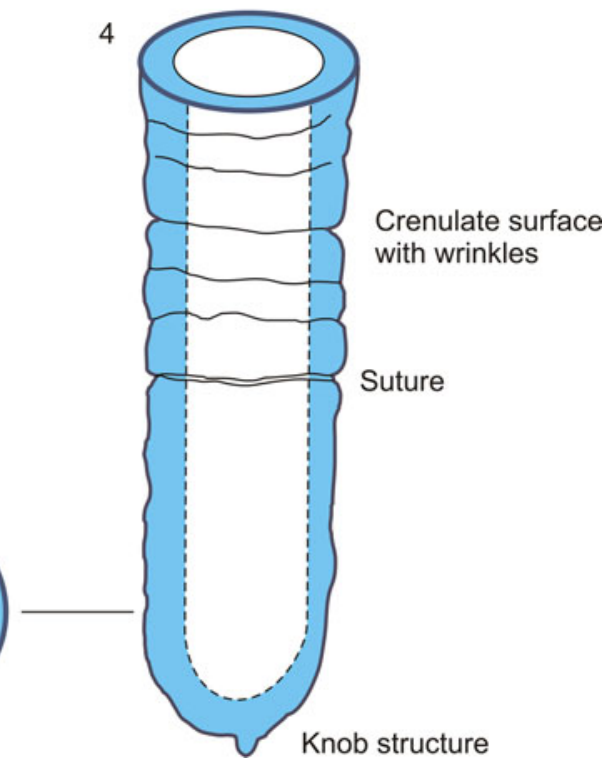

Figure 3. Sketch-drawings and morphologic terminology of new fossil taxa drawn proportionally to their dimensions; interrupted lines define the lumen within walls. $(\mathbf{1}, \mathbf{2})$ Holotype of Anulitubus n. gen. Moczydłowska in Moczydłowska et al.; (3) holotype of Coniculus n. gen. Moczydłowska in Moczydłowska et al.; (4) representative specimen of Fistula n. gen. Moczydłowska in Moczydłowska et al. Thick black outline of aperture and body surface in (3, 4) marks the wall outer veneer layer.

Repository and institutional abbreviation.-The material is reposited in the paleontological collections of the Museum of Evolution at Uppsala University (PMU). The collection is assigned as the Digermulen Peninsula fossils, Finnmark, Norway, and carry the catalogue numbers PMU 3473634757 , in which the last two digits refer to the individual specimen number.

\section{Systematic paleontology}

Terminology. - Although the higher taxonomic affinities of the fossils described herein are unresolved, they are hierarchically assigned to Metazoa and Eumetazoa based on the eukaryote classification of Adl et al. $(2012,2019)$ and dos Reis et al. (2015) (see also Cunningham et al., 2017). The term "animal" is used as an informal equivalent of metazoans in accordance with Blair (2009). Morphologic terminology (Fig. 3) follows the recommendations of the International Zoological Code of Nomenclature (www.iczn.org). For example, we use "tube," "tubular wall," or "tubular skeleton" to describe cylindrical structures and "conus," "conical wall," or "conical skeleton" for conical structures. We have therefore avoided the otherwise ambiguous terms "conotubular" or "conical tube." Similarly, we prefer "funnel-shaped segments or elements" (sensu Zhuravlev et al., 2012) instead of "funnel-shaped cylinders," and have refrained from using "apex," "apical end," or "basal apex" (sensu Cai et al., 2010, 2011, 2017; Cortijo et al., 2015) because of possible conflicting interpretation as embryonic segments that may have been embedded in the substrate. Finally, the term "apical flaring" was consistently used for defining portions of segments in Cloudina (Zhuravlev et al., 2012), which are oriented towards the distal end of the body.
Type locality. - All the taxa described in this study are from the coastal rock exposure at Árasulluokta Cove between the Árasulluokta and Manndrapselva rivulets on the southeastern coast of Tanafjorden, Digermulen Penninsula, Finnmark County, northeastern Norway. Mapsheet Langfjorden 223611, coordinates 420303 .

Type stratum.-All taxa described in this study are from the red-brown, thin-bedded slaty mudstone in the lowermost part of the Indreelva Member, Stáhpogieddi Formation. The type horizon is $\sim 40-42 \mathrm{~m}$ above the base of the Stáhpogieddi Formation coinciding with the top of the underlying Mortensneset Diamictite Formation; Ediacaran ca. 575 Ma.

Domain Eukarya Woese, Kandler, and Wheelis, 1990

Clade Metazoa Haeckel, 1874

Clade Eumetazoa Bütschli, 1910

Phylum uncertain

Genus Anulitubus new genus Moczydłowska in Moczydłowska et al.

Type species.-Anulitubus formosus n. gen. n. sp. Moczydłowska in Moczydłowska et al.

Diagnosis. - As for the type species.

Etymology.-From Latin ānulāt-us, - $a,-u m$, annulate, wearing a ring; ānul-us, $-i$, m., a ring; tub-us, $-i, \mathrm{~m}$., tube, pipe. Referring to the annulate tube or tube composed of rings.

Remarks.-There are several terminal Ediacaran (550-541 Ma) macroscopic annulated body fossils known, but none of them could be fully compared with the newly described taxon. 
Anulitubus $\mathrm{n}$. gen. is similar in an overall appearance and size to the annulate tapering fossil Conotubus Zhang and Lin in Lin et al., 1986, which Cai et al. (2011) considered to be a monotypic genus. The type species, Conotubus hemiannulatus Zhang and Lin in Lin et al., 1986, emend. Cai et al., 2011, has transverse annulations on the wall (Lin et al., 1986; Cai et al., 2011). Other diagnostic features include a "conical tube" structure composed of "nested funnel-shaped cylinders" with some transverse annulation (Cai et al., 2011, p. 48); note that "annulation" is not explicitly mentioned in this revised diagnosis. Conotubus is preserved as carbonaceous films and compressions or by pyritization (pyritized tube), replication or coating by clay minerals, and glauconitic casting of the tube (Cai and Hua, 2007; Hua et al., 2007; Cai et al., 2010, fig. 4C; Cai et al., 2011, 2012; Schiffbauer et al., 2014). The original composition was organic, as indicated by geochemical analyses (Hua et al., 2007; Cai et al., 2011; Schiffbauer et al., 2014).

Unlike Conotubus, Anulitubus n. gen. consists of a cylindrical annulate tube of uniform diameter. Its individual ringshaped segments are vertically stacked in contrast to the nested conical segments in Conotubus. The segments in Anulitubus n. gen. are defined and separated by grooves. An incomplete septum also occurs within the tube lumen, whereas Conotubus lacks septa and has flaring rims around the apertures on its funnelshaped segments.

Another annulate taxon, Cloudina Germs, 1972, emend. Cai et al., 2017, differs from Anulitubus n. gen. in being conical with multiple, nested elements forming a funnel-in-funnel tube construction. Cloudina also has transverse and/or oblique annulations that are distributed differently along the funnels in the various species (Cai et al., 2017). This fossil wall was thought to have a calcareous mineral composition (Germs, 1972; Grant, 1990; Cortijo et al., 2010, 2015; Zhuravlev et al., 2012; Penny et al., 2014; Wood et al., 2017), but it has been revealed to be originally organic and only taphonomically mineralized (Yang et al., 2020).

Sinotubulites Chen et al., 1981, emend. Cai et al., 2015 is distinguished by a cylindrical tube that is opened at both ends and variously circular, polygonal, or triangular in crosssection. The wall is multilayered with a tube-in-tube structure and transversely corrugated surface (Cai et al., 2015). The tube composition is considered to be organic and secondarily phosphatized (Hua et al., 2007), or primarily organic with lightly biomineralized (possibly calcareous or aragonitic) lamellae and forming exoskeleton (M. Chen et al., 1981; Hua et al., 2007; Z. Chen et al., 2008; Cai et al., 2010). Although not supported by geochemical analyses and without recognizing the original composition, Sinotubulites is maintained to be biomineralized and having shell (Cai et al., 2015; Wood et al., 2019).

Gaojiashania Yang et al., 1986 (in Liu et al., 1986; Chen et al., 2002; Cai and Hua, 2011) is another tubular fossil with external circular rings on the tube surface that may have been articulated (Cai et al., 2010). Gaojiashania is preserved as carbonaceous compressions, or pyritized or glauconized compressions, that appear to have organic or weakly mineralized skeleton (Cai et al., 2010) yet without reference to primary mineral.
Shaanxilithes Xiang et al., 1984, forms ribbon-like compression fossils with closely spaced annulations (Hua et al., 2004; Shen et al., 2007; Z. Zhang et al., 2015). The original structure may have been a cylindrical tube (Cai et al., 2010) that was originally organic (Meyer et al., 2012; Tarhan et al., 2014), but often found coated with clay minerals (Hua et al., 2004, 2007). Regardless of the uncertainty as to the morphology of elements forming the annulation (individual elements or thickenings of the wall, nested or stacked), this taxon may resemble Anulitubus $\mathrm{n}$. gen. only in having the original cylindrical shape.

\section{Anulitubus formosus new species Moczydłowska in Moczy- dłowska et al. Figures 4, 5}

\section{Holotype.-Specimen PMU 34736; illustrated in Figs. 4, 5.}

Diagnosis.-Macroscopic, cylindrical tubular, annulate body fossil having rigid, siliceous biomineralized and thick wall, circular cross section and open aperture at its distal portion. The proximal portion is closed and rounded. The tube consists of ring-shaped segments (annuli) that are of the same diameter and stacked vertically one upon the other. The annuli are defined by incised sutures (grooves) on the outer and inner surfaces of the wall. The sutures are transverse to the tube long axis and parallel. Incomplete septa within the lumen are located between the annuli and possess small opening in the center.

Description.-The tubular body fossil is $7.5-8.0 \mathrm{~mm}$ in total length and the portion exposed from the sediment is $4.0-5.0 \mathrm{~mm}$, whereas the additional portion visible in the CT image is $2.5-3.0 \mathrm{~mm}$ in length (Figs. 4.1, 4.2, 4.5, 4.6, 5.4). Circular in cross section, the tube has an outer diameter of $4.2 \times 5.2 \mathrm{~mm}$ and its wall thickness around the aperture is $0.5-0.7 \mathrm{~mm}$ including the outer edge of wall $\sim 100-135 \mu \mathrm{m}$ in thickness (Figs. 4.4, 7). The wall has a constant thickness along the length of tube and the wall is single-layered. Three annuli are separated by grooves that correspond to one another on inside and outside of the wall, but the wall is continuous (Figs. 4.1-4.4, 5.1, 5.2). The grooves are slightly undulate around the wall circumference, causing the length of individual annuli to vary insignificantly, but retaining overall similarity in size range (Figs. 4.1, 4.2, 4.5, 4.6, 5.1, 5.4). Each individual annular segment length is $1.0-1.5 \mathrm{~mm}$, and the groove length is $0.2 \mathrm{~mm}(\mathrm{~N}=1)$. The diameter of the tube lumen (empty cavity embraced by the wall) is $3.2-4.0 \mathrm{~mm}$. An incomplete septum with a central opening is seen within the lumen through the tube aperture and is located between the annuli (Figs. 4.3, 4.4, 4.7, 5.3). The incomplete septum divides the tube lumen into compartments or chambers, which are equivalent to the space embraced by the individual segment and are interconnected by the septal opening. The proximal portion of the tube is rounded and formed by a shallow, solid, cup-shaped element with a central knob directed outwards, while the inwards-oriented surface of this element is concave and meniscus-like (Fig. 5.4-5.7). The cup element diameter is $4.6 \mathrm{~mm}$, and its height is $2.5-3.0 \mathrm{~mm}$.

The tubular wall symmetry is radial and there is no differentiation in its morphology and construction with regard to 

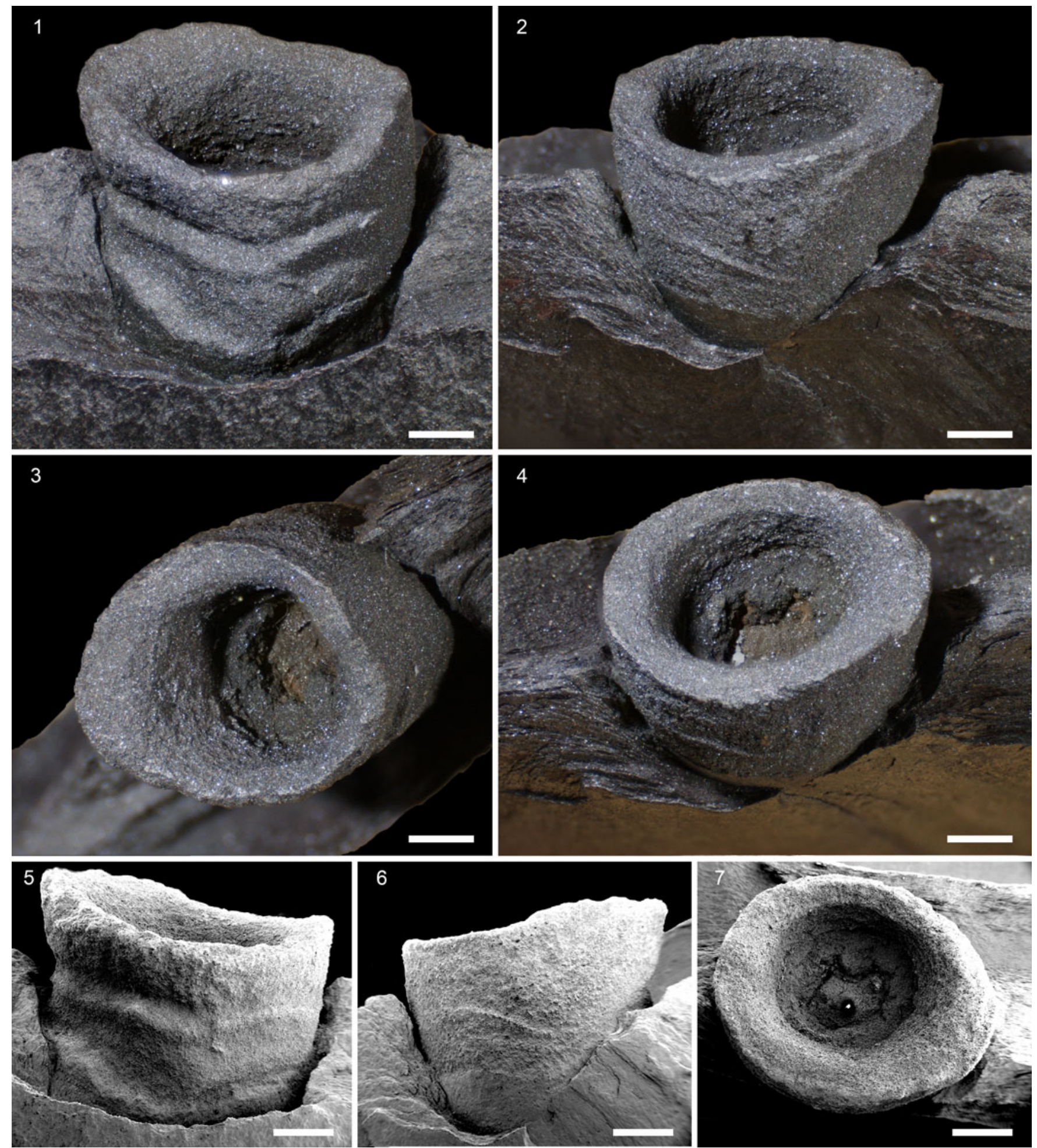

Figure 4. Macroscopic, mineralized tubular annulate Anulitubus formosus n. gen. n. sp. Moczydłowska in Moczydłowska et al., holotype specimen PMU 34736 Images from RLM (1-4) showing (1) front side view, (2) opposite side view, $(\mathbf{3}, \mathbf{4})$ apertural views with free lumen and visible incomplete septum. Images from STEM (5-7) showing (5) front side view, (6) opposite side, and (7) aperture. Scale bars $=1 \mathrm{~mm}$.

tube sides that might be interpreted as the ventral or dorsal side. The position of the distal open circular aperture relative to the closed proximal end with a central knob indicates the distinctive axis and the longitudinal or even posterior-anterior symmetry of the tube and its polarity.
Etymology.-From Latin forma, f., shape, figure, model, beauty; formosus, beautifully formed. Referring to "beautifully shaped annulate tube."

Material.-A single 3-D preserved specimen. 

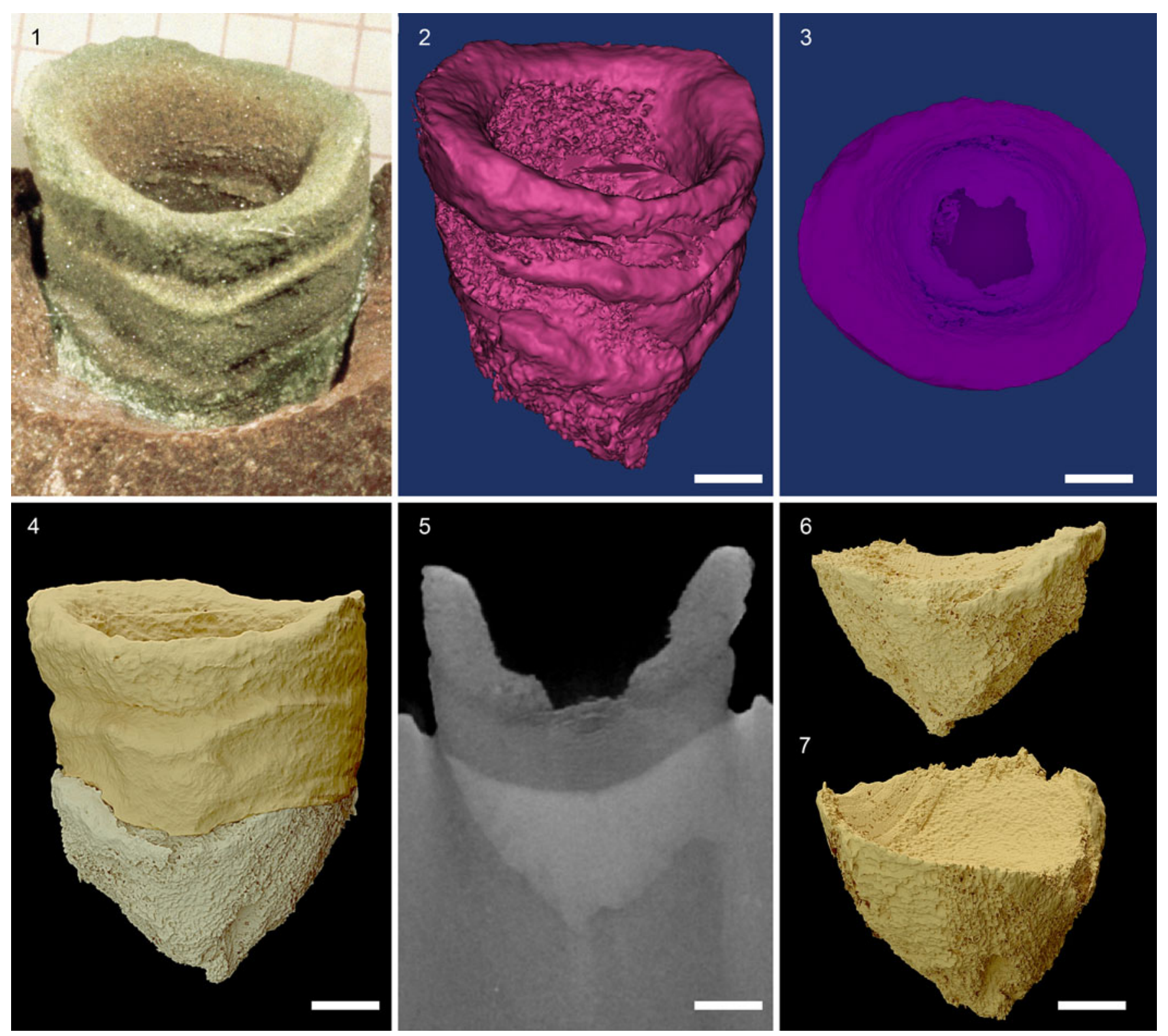

Figure 5. Macroscopic, mineralized tubular annulate Anulitubus formosus n. gen. n. sp. Moczydłowska in Moczydłowska et al. holotype specimen PMU 34736. Images from RLM in (1), and CT in $(\mathbf{2 - 7}) ;(\mathbf{1}, \mathbf{2})$ front view with three annuli, two grooves visible on the outer surface, and one groove on the inner surface within the lumen; (3) apertural view showing incomplete septum with central opening; (4) front view with lower portion that is embedded in the sediment (marked in gray color), showing the first annular segment together with the basal cup-shaped element; (5) mirror orientation of image in (4) with sediment entombing the specimen, but clearly showing the central knob at the tube base; $(6,7)$ mirror images of the cup-shaped element displaying the concave surface facing the tube lumen and radial symmetry. Scale bars in (1-7) are $1 \mathrm{~mm}$.

Preservation.-The holotype of Anulitubus formosus n. gen. n. sp. has been exposed through natural weathering, although the proximal extremity is still entombed in rock matrix (Fig. 5.1, 5.2, 5.4, 5.5). It was preserved on the bedding plane with the sediment laminae plastically bending around it (Fig. 4.1, 4.3). The oval cross-section of the aperture suggests limited compaction (Figs. 4.7, 5.3). The specimen is relatively short, consisting of three segments, and it could be considered as incomplete. However, the open distal portion of the rigid wall is very regular, without any breakage scars (Figs. 4.3, 4.4, 5.1-5.3), and is assumed to be the original aperture of the tube. The rounded portion that is entombed in the sediment is the original, closed proximal end of the body (Fig. 5.2, 5.4-5.7).

The shagrinate wall surface around the aperture (Fig. 4.1, 4.2) is covered by clay grains that include chlorite laths and some quartz microcrystals. These derive from clay fabric in the surrounding sediment and/or are diagenetic precipitates. The presence of aluminosilicate minerals is also confirmed by STEM EDS spectra (Fig. 6) and by the lathe-like crystallographic habit of chlorite and cubic and prismatic quartz microcrystals in our STEM images (not illustrated). However, the wall surface was originally smooth, as observed in CT images in which the material of the wall is distinguished from the 

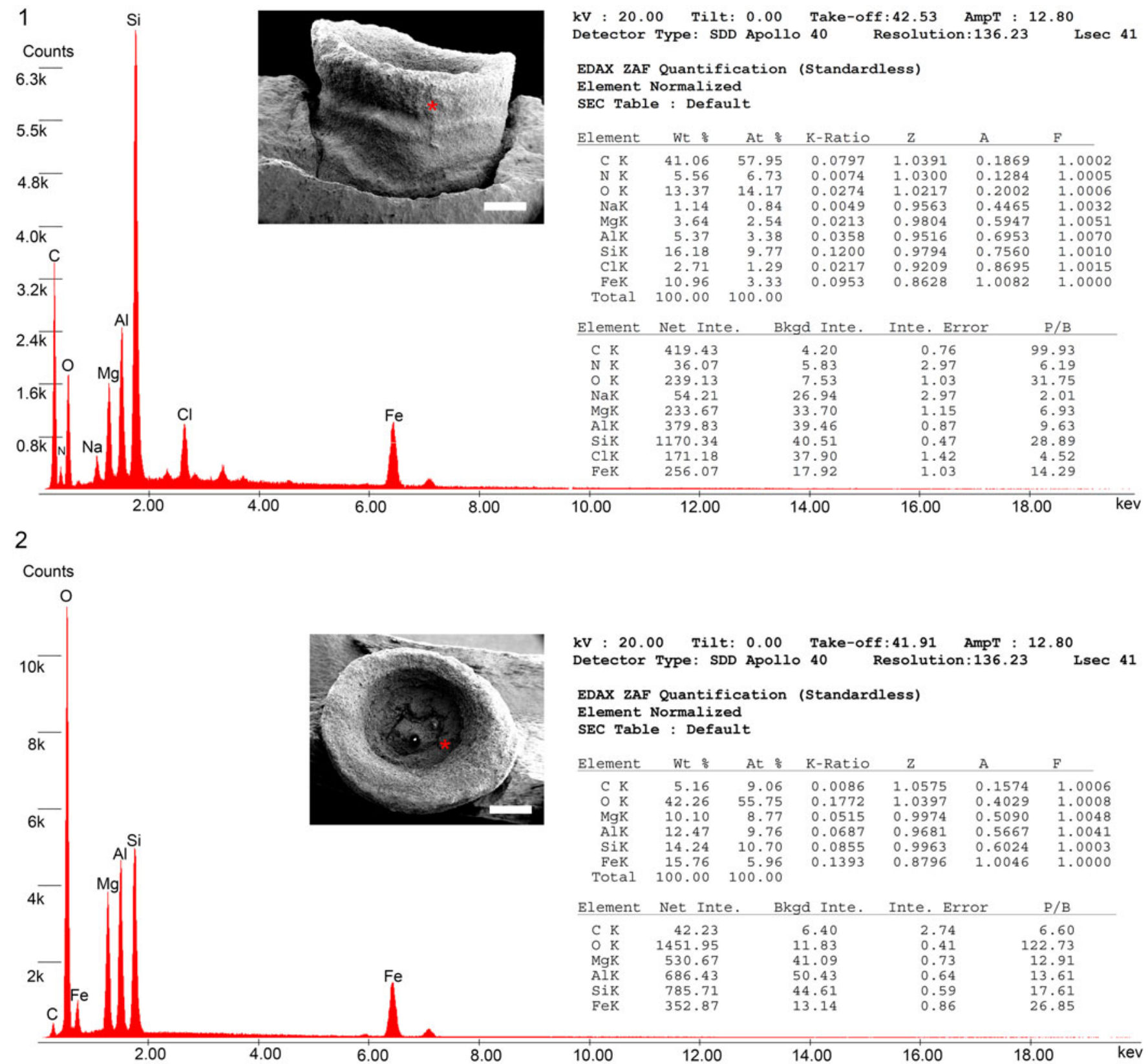

Figure 6. Wall composition of Anulitubus formosus n. gen. n. sp. Moczydłowska in Moczydłowska et al., holotype specimen PMU 34736, shown by elemental content analyzed by STEM EDS on the wall surface in (1) and the incomplete septum in (2). Measured points are marked by red asterisks. The point spectra are characteristic of silica forming the wall with high content of element carbon indigenous to the wall and remnant of organic matter.

sediment particles (Fig. 5), and geochemical analyses demonstrate that it is siliceous (see below).

The almost un-deformed and non-fractured tubular wall with an empty lumen indicates that the wall must have been originally robust - strong enough to resist burial conditions and retain its original 3-D form.

Wall construction and composition.-Having just a single specimen, it was inappropriate to section the tube wall to examine its internal construction and material composition, yet the available information from analyses on its surface and notable from the CT images is fairly conclusive. The CT images proved to be indispensable in revealing the wall construction of the tube portion that is concealed by the entombing sediment. They show not only the shape and closed proximal end, but also its internal construction, which allows inferences on the initial life history of the organism. The wall structure depicted in CT images (Fig. 5.2-5.7) is certainly single-layered and sharply differentiated into annular segments by grooves that show consistently their shape, dimensions, and 3-D special arrangement. Wall thickness and the diameter are constant (Fig. 5.2, 5.3). The annular segments have a smooth surface and appear solid in texture, whereas the grooves are more scabrous in texture, but clearly the wall is continuous (Fig. 5.2, 5.4). The proximal rounded portion of the tube is formed by the same material as the tube wall 

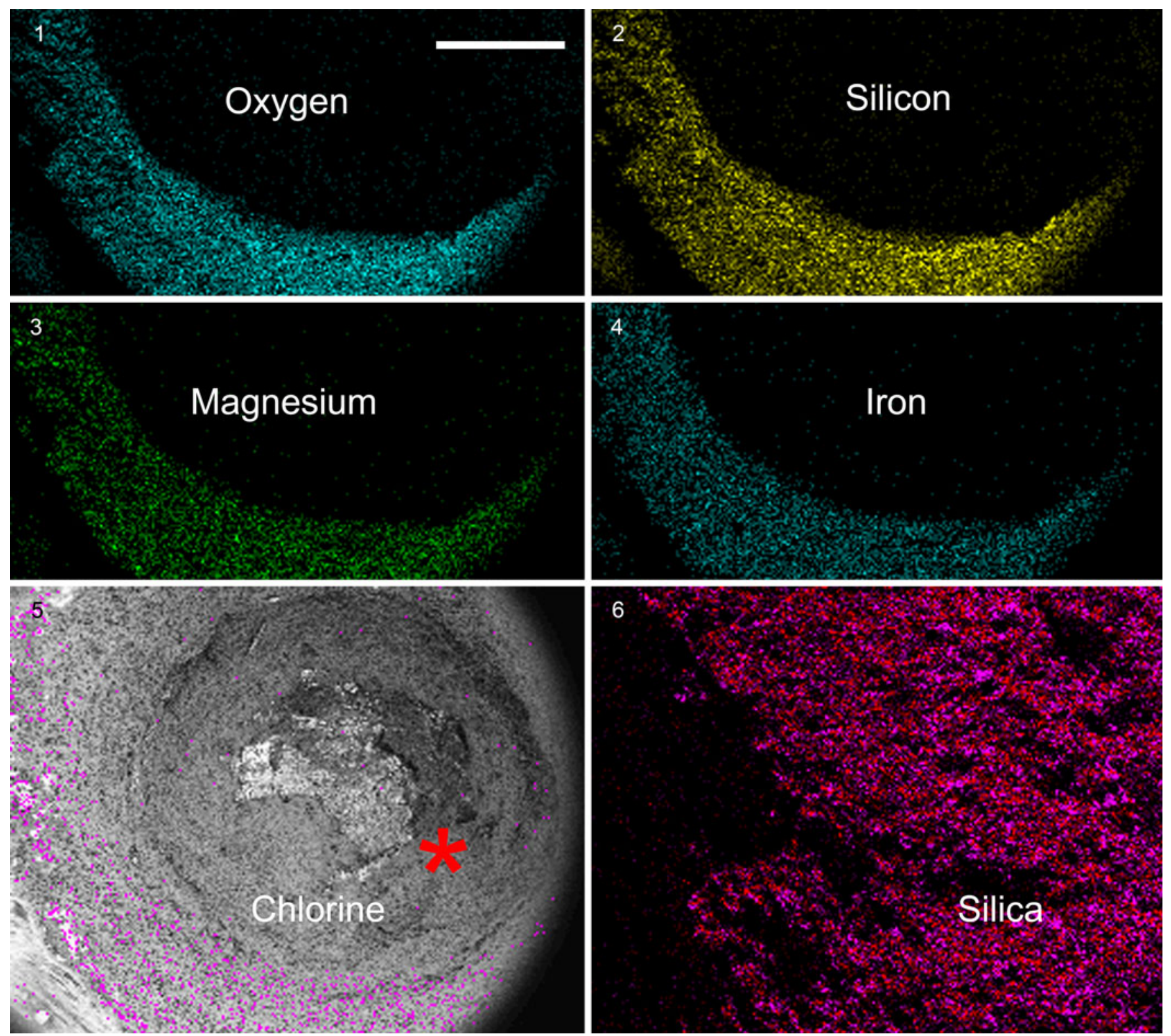

Figure 7. The wall composition of Anulitubus formosus n. gen. n. sp. Moczydłowska in Moczydłowska et al., holotype specimen PMU 34736 , shown by elemental mapping analyzed by STEM EDS on the wall aperture (1-5) and the incomplete septum surface (6). Asterisk in (5) indicates the measurement site of incomplete septum in (6). The intensity and homogenous distribution of $\mathrm{Si}$ and $\mathrm{O}$ are consistent with siliceous wall and incomplete septum, with some accessory elements derived from the host sediment. Scale bar in 1 for all images $=1 \mathrm{~mm}$.

(Fig. 5.4-5.7). The cup-shaped element at the base of tube has circular cross section, concave surface, and pronounced central knob with its positive relief directed downwards along the tube (Fig. 5.4, 5.6, 5.7). This element is an integral part of the tube, of almost the same diameter as the overlying stacked ring-shaped segments (annuli); it was the initial element in the tube construction and its robust base.

As observed in RLM, STEM, and CT images, and inferred from the state of preservation and wall mechanical properties, the material forming the wall was not morphoplastic (flexible), as it would be if it were organic, but rigid and originally biomineralized, as confirmed by geochemical analyses.

The STEM EDS analyses performed on the outer surface of the wall below the aperture and on the incomplete septum
(Fig. 6.1, 6.2) show the elemental content by the total weight percentage $(\mathrm{Wt} \%)$. The point spectrum of the wall quantified the very high content of carbon $(\mathrm{C}, 41.06 \%)$, oxygen $(\mathrm{O}$, $13.37 \%$ ), silicon ( $\mathrm{Si}, 16.18 \%)$, and iron (Fe, 10.96\%) (Fig. 6.1). Accessory elements with lower contents are aluminum $(\mathrm{Al})$, magnesium $(\mathrm{Mg})$, chlorine $(\mathrm{Cl})$, and sodium $(\mathrm{Na})$, ranging from $1.14-5.37 \%$. The presence of nitrogen $(\mathrm{N}$, $5.56 \%$ ) is significant because of its potential bonds with other elements in forming organic matter (Fig. 6.1). The elemental spectrum of incomplete septum shows much lower content of C (5.16\%), higher of O (42.26\%), and no nitrogen, whereas Si is comparable (14.24\%) and metal elements are relatively higher in their contents: $\mathrm{Fe}(15.76 \%), \mathrm{Al}(12.47 \%)$, and $\mathrm{Mg}(10.10 \%)$ (Fig. 6.2). The lower content of $\mathrm{C}$ in incomplete septum might 
be due to the lower organic-richness of this morphologic element or it may be preservation bias. The high content of $\mathrm{C}$ in the wall and remarkable lack of calcium $(\mathrm{Ca})$ in the spectra, as well as the absence of carbonate minerals or calcareous cement in the host sediment, which could provide potential contamination by $\mathrm{C}$, suggest that $\mathrm{C}$ is indigenous to the fossil wall. The elements $\mathrm{C}, \mathrm{O}$, and $\mathrm{N}$ are typical constituents of organic matter, and their association in the observed spectra suggests that the organic matrix of the wall is preserved. Nitrate minerals are not recorded in the studied succession and $\mathrm{N}$ is not diagenetically induced or a contaminant in the specimen wall. The elements $\mathrm{Si}$ and $\mathrm{O}$ are typically combined in the mineral opaline silica (silica, silicon dioxide, $\mathrm{SiO}_{2}$ ), which is further confirmed by the Laser-Raman spectroscopy. The elements $\mathrm{Fe}, \mathrm{Al}, \mathrm{Mg}$, and less abundant $\mathrm{Na}$ and $\mathrm{Cl}$ are components of the wall and incomplete septum spectra and are interpreted as derived from the aluminosilicate minerals and iron oxides attached to the specimen in parts and present in the burial environment.

The STEM EDS elemental mapping of the wall transverse plane displayed predominantly $\mathrm{Si}$ and $\mathrm{O}$, and additionally $\mathrm{Mg}$, $\mathrm{Fe}$, and $\mathrm{Cl}$ within the wall and across its thickness (Fig. 7.17.5). The elemental map of the incomplete septum within the tube lumen shows clearly $\mathrm{Si}$ and $\mathrm{O}$ contents (Fig. 7.6). The abundance and uniform and continuous distribution pattern of $\mathrm{Si}$ and $\mathrm{O}$ in all measured points and in different parts of the specimen (several, although not illustrated) are compelling evidence for silica forming the wall. The accessory elements $(\mathrm{Mg}, \mathrm{Fe}, \mathrm{Cl})$ are derived from the diagenetic minerals attached to the wall. The distribution pattern of elements in the wall is homogeneous and shows that the wall was composed of material that was uniform in structure and density, without layering, and not incorporating any macrocrystals, grains, or mineral fragments.

The lack of elemental Ca, phosphorus (P), and sulphur (S) in the wall spectra indicates the absence of carbonate, phosphate, and sulphate minerals, respectively, in the wall as potential constituents of the skeleton and rules-out the possibility of such primary minerals being diagenetically permineralized by silica.

The Laser-Raman spectra acquired on the wall surface at several points are recognized as quartz (crystalized $\mathrm{SiO}_{2}$ ) and anatase (titanium dioxide, $\mathrm{TiO}_{2}$ ) minerals, and as carbonaceous material by the disordered (D-) and graphitic (G-) bands characteristic for sp2-bonded, graphitic carbon (Fig. 8; Supplementary Data). The quartz signature in the fossil wall is strong and differs clearly from that of the host sediment, which was examined for comparison, and its intensity distinguishes the primary mineralogy of the fossil from the minor detrital and diagenetic quartz in the sediment (see below and under Coniculus n. gen. and Fistula n. gen.; Figs. 14, 15, 21; Supplementary Data). The wall was originally composed of silica and diagenetically transformed into a microcrystalline quartz phase, while anatase was derived from the depositional environments. The carbonaceous material preserved within the mineralized wall is confirmed to be the wall's integral component, because it was detected by STEM EDS analysis, and constituted the organic matrix for precipitation of silica in the process of biomineralization (see under Skeletal biomineralization).

Anatase is a common accessory mineral in siliciclastic rocks and it likely has a diagenetic origin from muscovite alteration in the Indreelva sediment. Anatase that is recorded on the fossils' surface is a contaminant from the entombing sediment, but it is also possible that it could derive from the biogenically mediated crystallization on the decaying organic matter substrate during burial (Supplementary Data).

Diagenetic alteration via calcification, phosphatization, pyritization, and aluminosilicification, which is typical of the terminal Ediacaran body fossils (compare Cai and Hua, 2007; Cortijo et al., 2010, 2015; Cai et al., 2012, 2014; Zhuravlev et al., 2012; Schiffbauer et al., 2014), does not occur in the Digermulen Peninsula succession. Silica was the original mineral in the wall of studied fossils and the host sediment cement is only insignificantly silicified (Meinhold et al., 2019a; Supplementary Data).

Remarks.-As aforementioned for the new monotypic genus, its type species Anulitubus formosus $\mathrm{n}$. gen. $\mathrm{n}$. $\mathrm{sp}$. is dissimilar to any known Ediacaran body fossil by the spatial arrangement of annular segments and by the presence of a cup-shaped element at the proximal part of the tube.

\section{Genus Coniculus new genus Moczydłowska in Moczydłowska et al.}

Type species.-Coniculus elegantis n. gen. n. sp. Moczydłowska in Moczydłowska et al.

Diagnosis.—As for the type species.

Etymology.-From Latin conus-i, m.; cuniculus, m., cone. Referring to conical shape of the wall.

Remarks.-The new monotypic genus differs from other Ediacaran macroscopic conical fossils, either organic or biomineralized, by the morphologic simplicity of its conical, smooth on the surface, and biomineralized wall that is double-layered and siliceous. Coniculus n. sp. may resemble superficially Multiconotubus Cai et al., 2017, which is a multilayered, "conical tube" with open aperture and closed "apical" end (it is proximal) and consists of fully nested cone-shaped layers that are biomineralized (Cai et al., 2017). The funnel-shaped and tapering specimens of Multiconotubus are smooth on the surface, and has cone-in-cone structure (Cai et al., 2017, fig. 8). However, the phosphatized specimens are fragmentarily preserved and without their terminations, and thus document neither the apertural and proximal ends, nor the proximal end being closed and interpreted as anchoring apparatus by Cai et al. (2017). The morphology of the entire body remains uncertain, as is the primary mineralogical composition in assumed biomineralized wall.

\section{Coniculus elegantis new species Moczydłowska in Moczydłowska et al.}

Figures 9-11

Holotype.-Specimen PMU 34737; illustrated in Figures 9, 10.

Diagnosis.-Macroscopic, elongate conical, thick-walled siliceous biomineralized skeleton with open circular aperture 


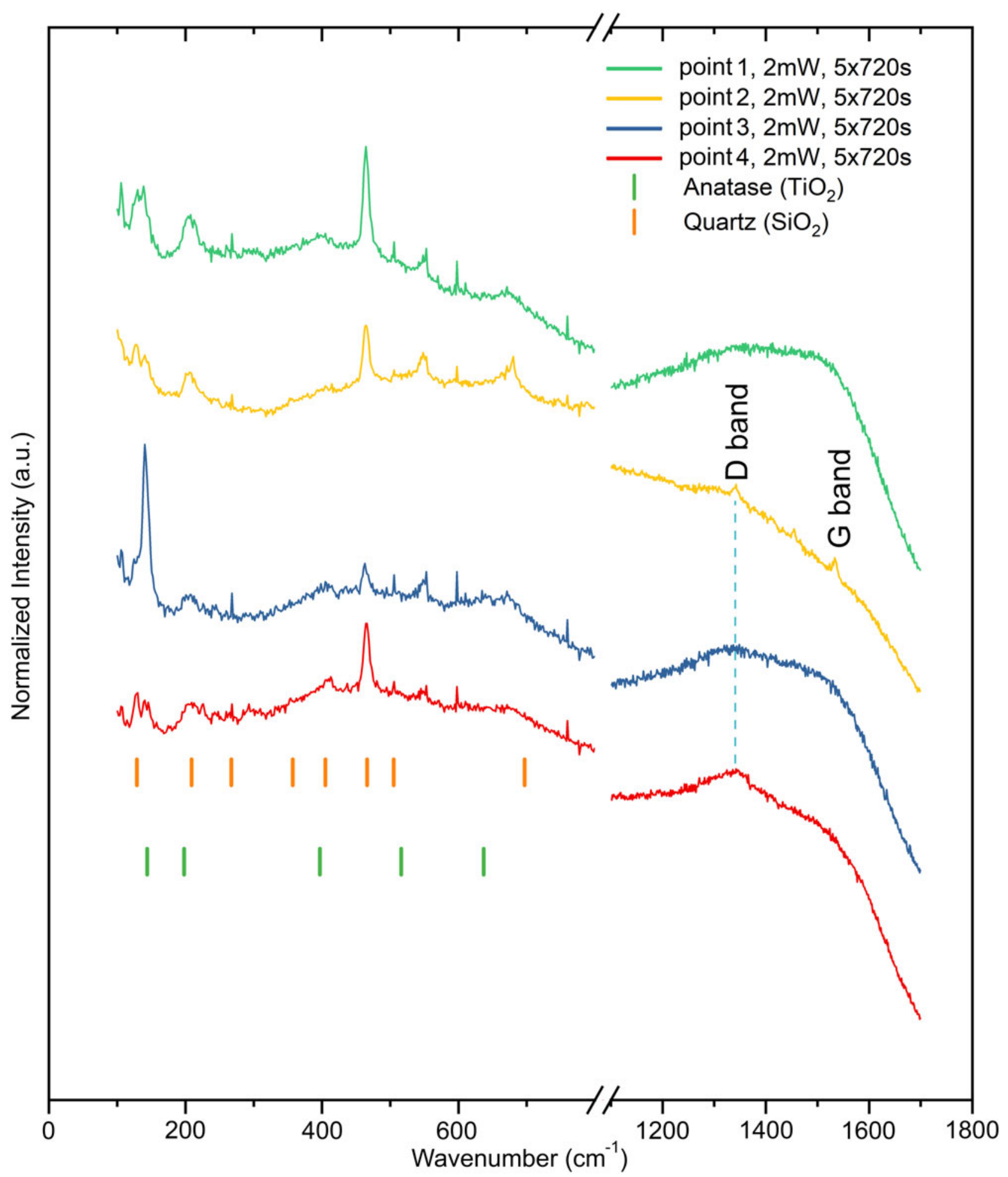

Figure 8. The wall composition of Anulitubus formosus $n$. gen. n. sp. Moczydłowska in Moczydłowska et al. revealed by the Laser-Raman spectra acquired on the wall surface in several points and showing the signatures of quartz and anatase minerals, and spectral disordered D-band and graphitic G-band of carbonaceous material that is admixed in the mineralized wall. Holotype specimen PMU 34736 illustrated in Figure 4. The specimen wall is composed of quartz that is recrystallized from the original amorphous opaline silica into microcrystalline phase during diagenesis. The anatase derived from the burial environment and is a contaminant from microcrystals attached on the specimen wall surface. The green and orange color tick marks are the positions of strong Raman peaks of anatase $\left(\mathrm{TiO}_{2}\right.$, $\mathrm{RRUFF}$ ID: R060277) and quartz ( $\mathrm{SiO}_{2}$, RRUFF ID: R040031), respectively. 


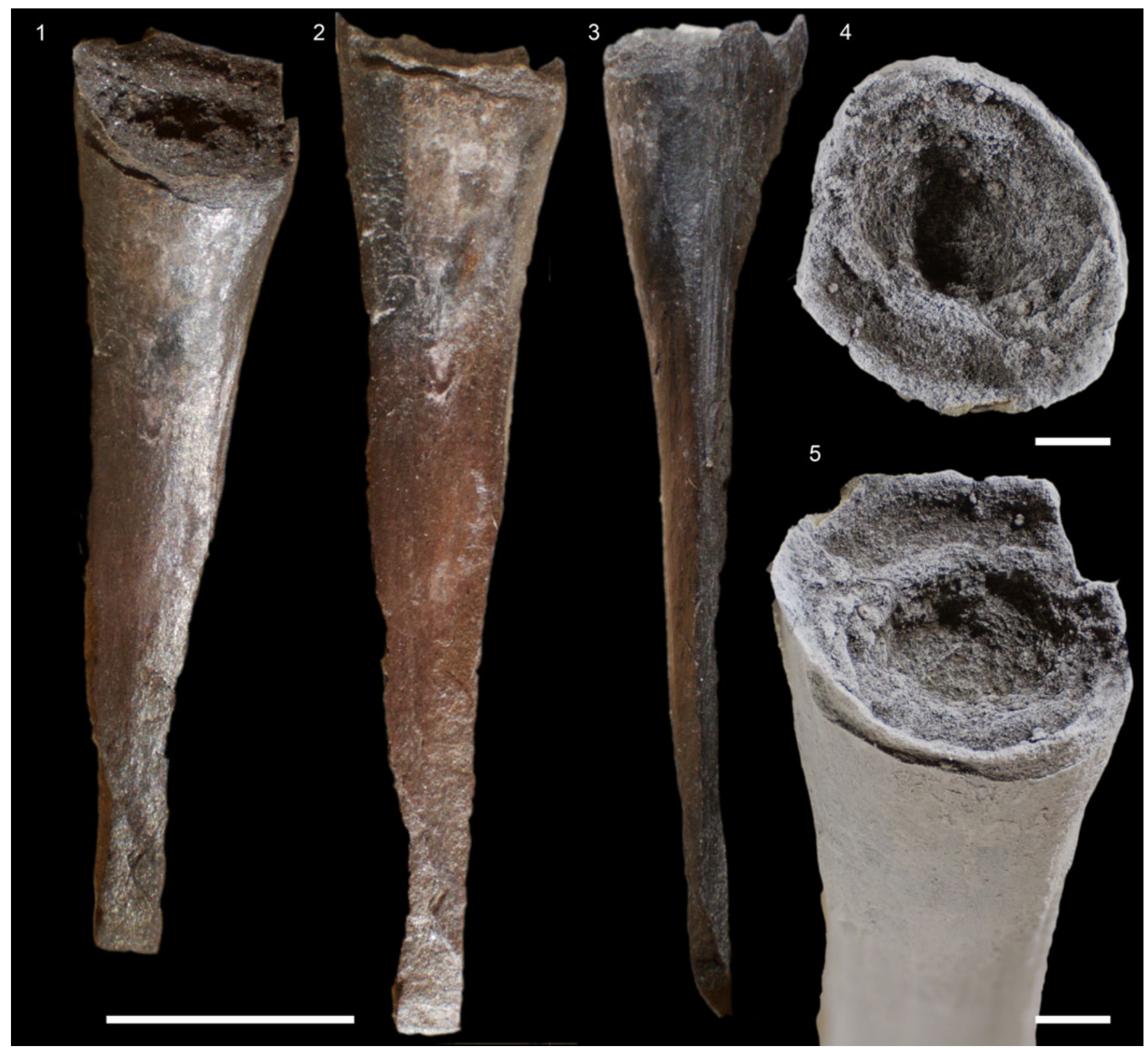

Figure 9. Macroscopic, mineralized conical Coniculus elegantis n. gen. n. sp. Moczydłowska in Moczydłowska et al., holotype specimen PMU 34737. (1, 2) Images from RLM in a front side view; $(\mathbf{3})$ opposite side view; and $(\mathbf{4 , 5})$ apertural view. Distinct outer veneer layer of the wall is seen as a sharp outline in the apertural, circular cross sections $(\mathbf{4 , 5})$ and can be chipped off at the edge $(\mathbf{1}, \mathbf{5})$. The thicker inner wall layer is seen around the aperture $(\mathbf{1}, \mathbf{4 , 5})$ and the lumen is infilled with sediment in the lower portion (5). The end of cone is entombed in the sediment at approximate level marked by white arrow in (2) and recognized by the relief and by comparison with CT images. Scale bars for $(\mathbf{1 - 3})=6 \mathrm{~mm}$, and for $(\mathbf{4 , 5})=1 \mathrm{~mm}$.

and narrow, closed proximal portion. The cone wall is double-layered and consists of an outer, very thin compact layer (veneer layer) with distinct smooth, glossy surface, and an inner, less-dense and thicker layer. Both layers are of constant thicknesses. The cone lumen is hollow.

Description. - Conical body fossil is $12-13 \mathrm{~mm}$ in total length and its widely open distal aperture is at maximum $4.0 \times 5.0$ $\mathrm{mm}$ in diameter. The cone tapers sharply to the narrow proximal end that is $1.5-2.0 \mathrm{~mm}$ in width, as seen in CT images (Fig. 10), but is also recognizable by topological relief from the entombing sediment (Figs. 9.1, 9.2, 11.2). The smooth-surfaced conical wall is stiff, solid, mineralized, and slightly concave at the aperture; it embraces a hollow central lumen (Fig. 9.4, 9.5).

The wall total thickness is $0.5-1.0 \mathrm{~mm}$, including the distinct outer veneer layer of the wall that is $0.1-0.3 \mathrm{~mm}$ in thickness and is observed in cross sections of apertural or broken portions in all specimens (Figs. 9.1, 9.4, 9.5, 10, 11.1, 11.2, $11.4,11.5)$. The veneer layer forms a sharp outline of the wall at the aperture or sharp edge when broken, and covers the cone. The wall inner layer appears as a narrow circular belt in the apertural end of the cone and in sections alongside the cone (Figs. 9.1, 9.4, 9.5, 11.4). 


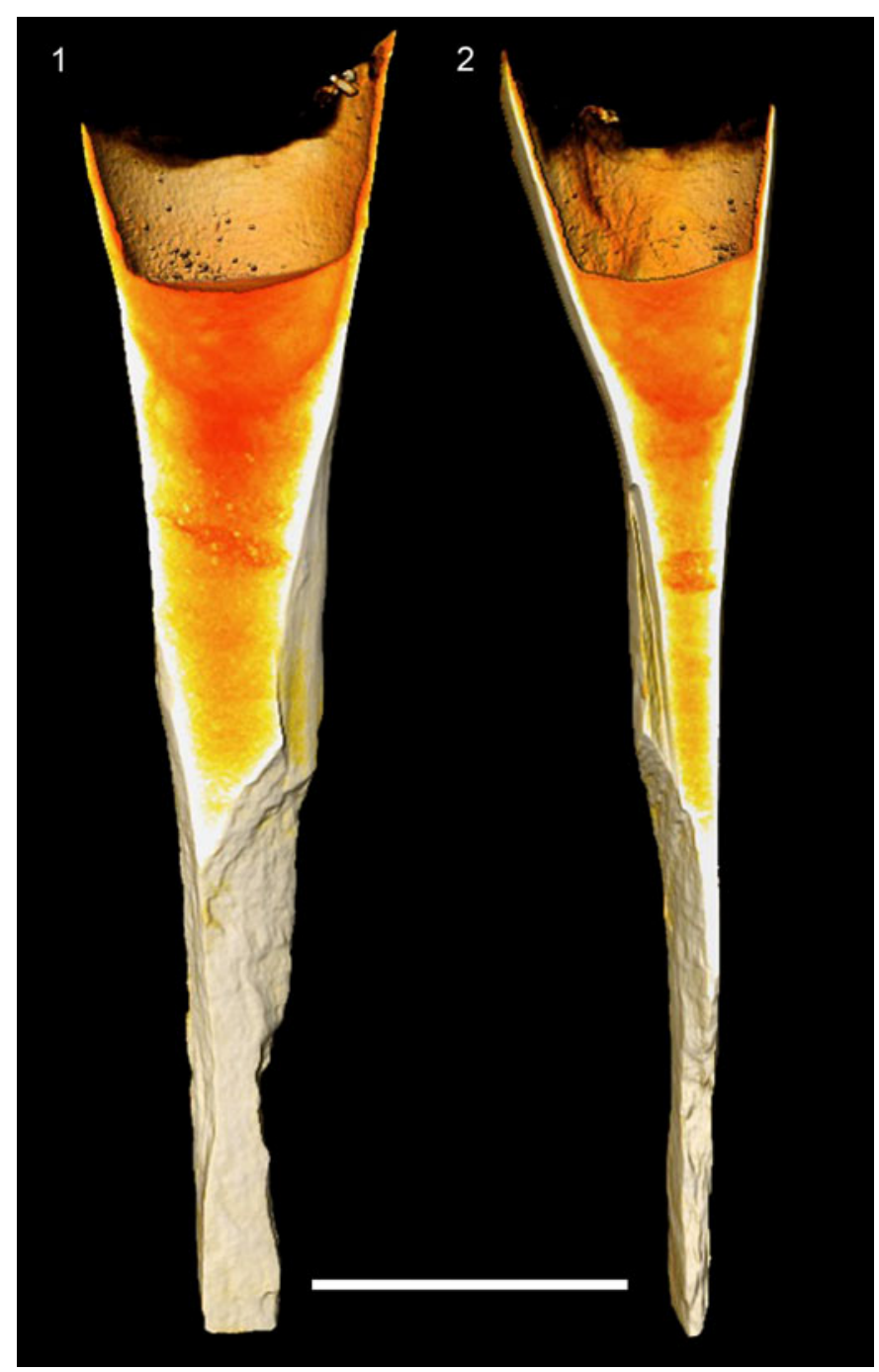

Figure 10. Coniculus elegantis n. gen. n. sp. Moczydłowska in Moczydłowska et al. CT images in a front side view of the specimen (1) and a mirror and turned side view (2) showing constant wall thickness and sharp edges, and the lumen lower part infilled with the sediment (yellow color in images). Scale bar $=5 \mathrm{~mm}$.

Observed in the CT vertical transect image (Fig. 10), the upper portion of the cone lumen, $\sim 5.7 \mathrm{~mm}$ in length, has a rounded bottom and is the sediment-infilled surface seen also through the aperture of the specimen. The sediment infilling continues from this surface to a narrower conical extension of the lumen, $\sim 2 \mathrm{~mm}$ in length, and continues towards the proximal end of the cone. The wall section is sharp in appearance and of constant thickness.

The holotype dimensions are: conical wall length 12.0 $13.0 \mathrm{~mm}$; outer diameter at aperture $4.0 \times 5.0 \mathrm{~mm}$; diameter at proximal portion $2.0 \mathrm{~mm}$; wall total thickness $0.6-0.8$ $\mathrm{mm}(600-800 \mu \mathrm{m})$; wall outer veneer layer thickness $0.1-$ $0.2 \mathrm{~mm}(100-200 \mu \mathrm{m})$; lumen diameter at aperture $3.5 \times 4.0$ $\mathrm{mm}$. Dimensions of other, fragmentary preserved specimens are: wall length is $10.0-13.0 \mathrm{~mm}$; outer apertural diameter $2.5 \times 3.2 \mathrm{~mm}$ to $3.0 \times 4.0 \mathrm{~mm}$; diameter at proximal portion $1.5 \times 2.0 \mathrm{~mm}$ to $2.0 \times 3.0 \mathrm{~mm}$; wall total thickness $0.5-1.0$ $\mathrm{mm}$; wall outer veneer layer thickness $0.2-0.3 \mathrm{~mm}(\mathrm{~N}=3)$.
Etymology.-From Latin elegans, -antis, adj., fine, elegant. Referring to very regular shape of the conical wall ("a little elegant cone").

Materials.-Four 3-D preserved specimens. Additional to the holotype are specimens: PMU 34738, 34739, and 34740, illustrated in Figure 11.

Preservation.-The holotype is very well preserved, only minimally flattened, and preserving a hollow central lumen (Fig. 9.1, 9.4, 9.5). The lumen is filled in with host sediment only in its lower portion (Figs. 9.4, 10). This proximal portion of the specimen is entombed in the red-brownish host sediment (Fig. 9.1-9.3), but is distinguished by the relief of dark gray color and glossy surface of the cone wall forming the narrow end (Fig. 9.1, 9.2). The cone surface is encrusted in small patches by chlorite, the early diagenetic clay mineral recognized in STEM images (Fig. 11.6).

Three other specimens are preserved with sediment chips attached to their surface or covering part of the cone (Fig. 11.1-11.3), and one specimen has a broken proximal portion (Fig. 11.3). They have tapering proximal portions (Fig. 11.1, 11.2), and their diameters are in the same range. The lengths of the specimens are comparable, although uncertain in a total range because of the fragmentary preservation. The specimens have their lumina filled with host sediment. The broken proximal portion shows the section of the mineralized wall in contrast to the lumen infilling by sediment and recrystallized quartz, and demonstrates that the lumen extended down from the aperture throughout the entire cone (Fig. 11.311.5). The constant wall thickness is visible in cross-sections of all specimens. The outer veneer layer of the wall is well preserved under the peeled-off sediment that covered the specimen surface (Fig. 11.1, upper part) as a smooth surface and continued into a sharp edge. When fractured on the side of the cone, the veneer layer is exposed as a sharply outlined scar, in contrast to the underlying inner layer of the wall with a less-dense texture (Fig. 11.2). The texture of the inner layer is poorly observed because the specimens' cross sections are mostly covered by clay minerals, but this layer is recognizable by its constant thickness around the aperture, and clear delimitation from the veneer layer (Figs. 9.1, 9.4, 9.5, 11.1, 11.2).

All specimens are slightly compressed parallel to the bedding and cleavage planes. Their apertures are oval $(4.0 \times 5.0$ $\mathrm{mm}, 3.7 \times 4.0 \mathrm{~mm}, 3.0 \times 4.0 \mathrm{~mm}, 2.5 \times 3.2 \mathrm{~mm}$ ) and their conical walls are only slightly deformed. The specimens were originally circular in cross-section and regularly conical, and show brittle fracturing of the wall (Figs. 10, 11.1, 11.2).

Wall construction and composition.-Morphological features and the state of preservation reveal a double-layered wall in which the layers are distinguished by their texture and constant thicknesses. The glossy veneer layer with a sharp edge at the aperture formed a compact surface layer, and the inner thicker layer provided substantial robustness to the wall. Both layers constructed the resistant skeleton of the organism.

For identification of the wall composition, a simple chemical test by controlled dropping of concentrated (45\%) hydrofluoric acid (HF) on the exposed wall (Fig. 11.3) resulted in 


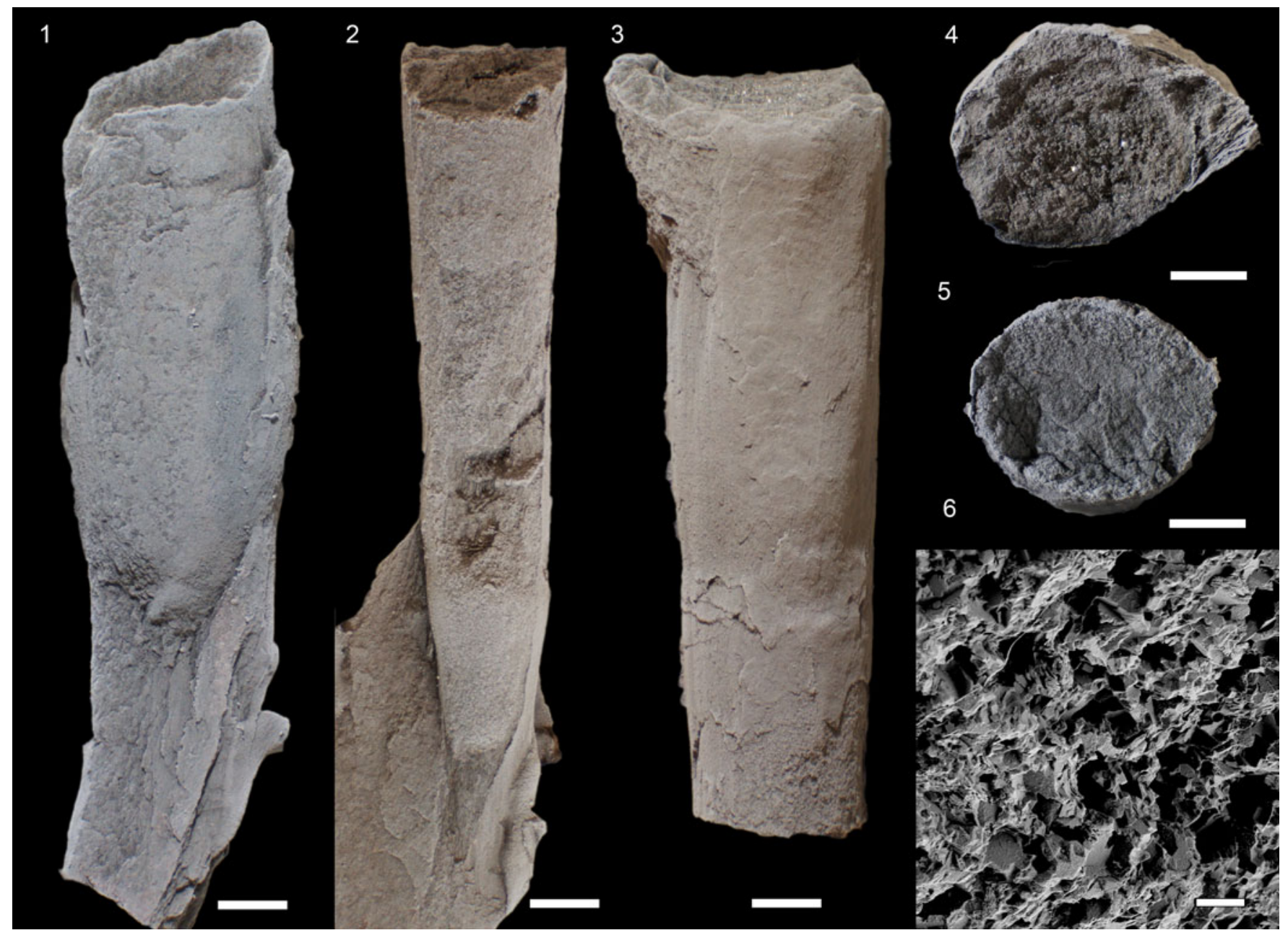

Figure 11. Coniculus elegantis n. gen. n. sp. Moczydłowska in Moczydłowska et al. Images from RLM (1-5) and STEM (6). Conical wall with tapered closed proximal ends that are entombed in sediment $(\mathbf{1 , 2})$ or broken apart $(\mathbf{3})$, and apertural ends showing sharp-edged outer veneer layer $(\mathbf{4 , 5})$. Lumen is infilled with host sediment $(\mathbf{4 , 5})$. The surface of specimens may be partly coated by the sediment aluminosilicates, including chlorite $(\mathbf{6}$, enlarged from $\mathbf{1}$, right side). White arrow in $(\mathbf{2})$ indicates position of proximal end. Specimens PMU 34738 (1), PMU 34740 (2), PMU 34739 (3-5). Scale bars in (1-5) $=2 \mathrm{~mm}$, in (6) = $3 \mu \mathrm{m}$.

rapid corrosion of the surface, which is consistent with dissolving silica from the wall. The same treatment of the sediment was almost non-reactive. The reaction to hydrochloric acid $(10 \%$ $\mathrm{HCl}$ ) applied on the specimen and the entombing sediment was negative (not dissolving minerals) and excludes the presence of carbonate minerals, which is independently proven by the lack of $\mathrm{Ca}$ in elemental spectra of the tube wall (see below). The siliceous composition of the wall is affirmed by the STEM EDS and EMP EDS analyses and the Laser-Raman spectroscopy.

The STEM EDS elemental content was measured on the wall surface and the wall apertural cross section of the holotype (Fig. 9.1, 9.2) by the total weight percentage (Wt \%). The point spectrum on the wall section shows the high content of $\mathrm{C}$ (33.31\%), O (37.88\%), Si (13.60\%), and $\mathrm{N}(8.20 \%)$ (Fig. 12.1). Additional elements, such as $\mathrm{Cl}$, manganese (Mn), $\mathrm{Al}$, and $\mathrm{Mg}$ are in lower contents, between $<1.00 \%$ and $<3.00 \%$, and the sulphur (S) content is only $0.33 \%$ (Fig. 12.1). The point measured on the wall surface also shows high content of C (19.06\%), O (40.02\%), and Si (9.59\%) but not N (Fig. 12.2). The elements $\mathrm{Fe}$ (19.48\%), $\mathrm{Al}(6.81 \%)$, and $\mathrm{Mg}(4.47 \%)$ are also significant components. The elemental spectrum acquired on another point of the wall surface showed similar content of $\mathrm{C}$ (16.99\%), O (43.97\%), and silicon (10.91\%), and less abundant $\mathrm{Fe}(14.95 \%), \mathrm{Al}(8.95 \%), \mathrm{Mg}(3.10 \%)$ and potassium $(\mathrm{K}$; $1.12 \%)$ (not illustrated).

The high content of $\mathrm{Si}$ and $\mathrm{O}$ in all measured points is conclusive evidence of the siliceous composition of the wall. Carbonate minerals are absent in the specimen wall and in the sediment $(\mathrm{HCl}$ test; $\mathrm{Ca}$ absence in the wall elemental EDS spectra; XRD spectra of the sediment; Figs. 12, 21; Supplementary Data). Because of this absence, the abundance of $\mathrm{C}$ in the wall is inferred to be indigenous. The abundance and elemental association of $\mathrm{C}, \mathrm{O}$, and $\mathrm{N}$ indicate an organic matrix within the siliceous wall, comparable to what is inferred for Anulitubus n. gen. The substantially higher content of $\mathrm{C}$ observed in the wall inner layer (apertural section; Fig. 12.1) than in the veneer layer (wall surface; Fig. 12.2) may not be a random or biased occurrence, but may be explained by a predominant occurrence of organic matrix in the inner layer. This layer has a less dense texture and might have had higher content of organic matrix in comparison with the compact veneer layer. The substantial amounts of 

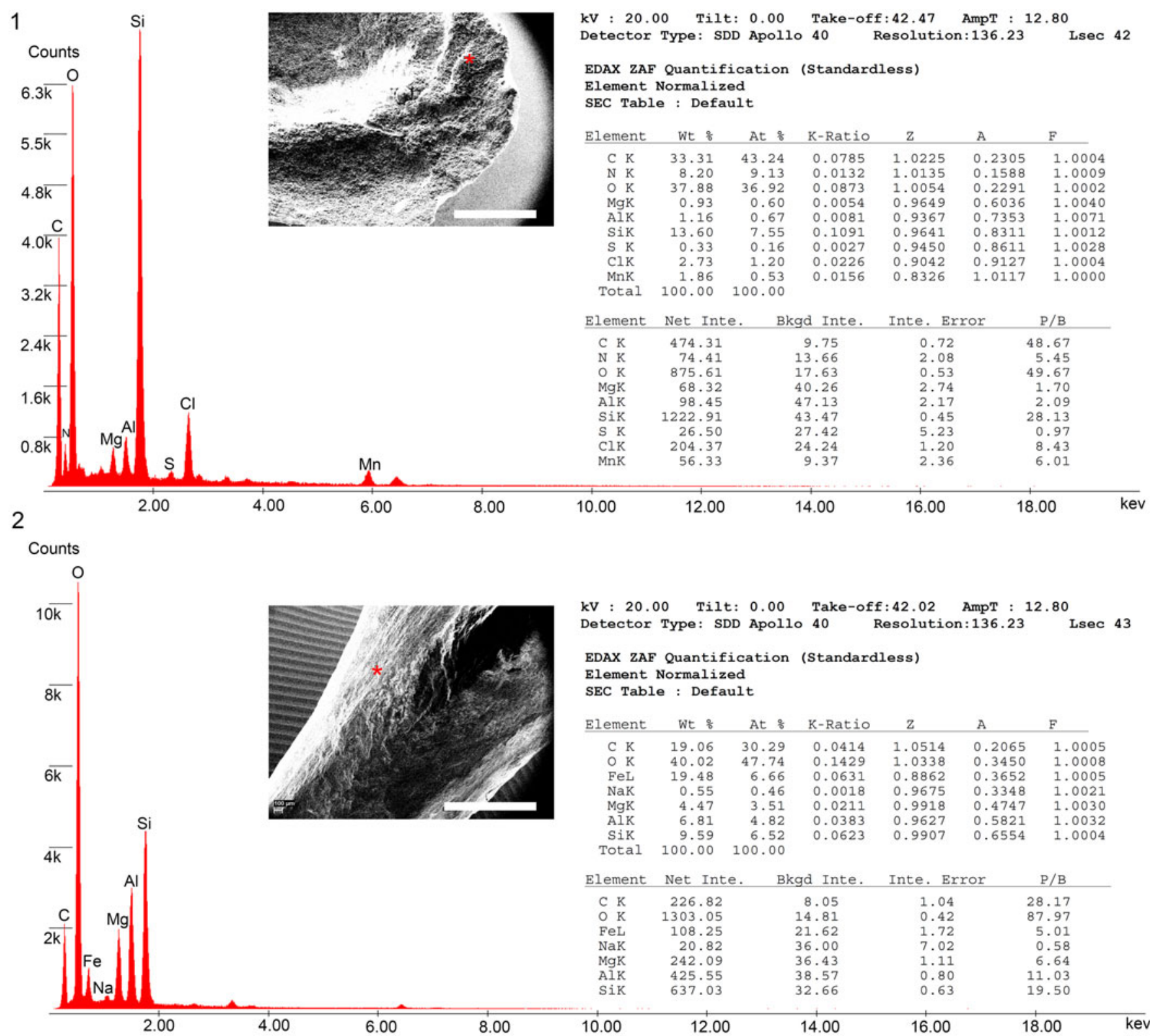

Figure 12. The wall composition of the Coniculus elegantis n. gen. n. sp. Moczydłowska in Moczydłowska et al., holotype specimen PMU 3434737 analyzed by STEM EDS on the cross section of the wall inner layer (1) and wall surface veneer layer (2). The highest elemental content of Si and O is indicative of siliceous composition with admixture of $\mathrm{C}$ and $\mathrm{N}$ from organic matrix. Red asterisks mark the measurement points on the insets of STEM images. Scale bars in STEM images $=1 \mathrm{~mm}$.

the metal elements, including $\mathrm{Fe}, \mathrm{Al}, \mathrm{Mg}, \mathrm{Mn}$, and sodium ( $\mathrm{Na}$ ), in the wall are inferred to be derived from the aluminosilicate minerals and iron oxides present in the burial environments.

The Laser-Raman spectra acquired in three points on the wall of holotype indicate quartz and anatase signatures (Fig. 13; Supplementary Data), and prove that the wall (Figs. $9,10)$ was composed of silica (presently in quartz phase), whereas anatase originated from the host sediment or precipitated from the depositional environments (see also under Anulitubus n. gen.).

The wall of Coniculus n. gen. examined in petrographic thin section in light microscopy parallel light and with crossed polarizers (Fig. 14.1, 14.2, respectively) appears to be composed of a fine-grained mixture dominated by opal (amorphous silica), quartz, and seldom sheet silicates. The outer veneer layer is compact and sharp in line, as seen in the vertical section, and the underlying inner layer is a mixture of opal and very fine microcrystalline quartz and silicates. The lumen is infilled by the host sediment and is fractured by secondary chalcedony veins; the broken apertural portion is massively covered by elongated crystals of secondary chalcedony (Fig. 14.1, 14.2, upper edge of specimen). There is no sign of any pseudomorphs, replication by other minerals, or surface encrusting. Subsequent EDS survey using EMP of the same thin section confirmed that the wall is mainly composed of pure silica with admixture of a clay-like phase. The infill of the lumen is dominated by the crystallized secondary silica (chalcedony). 


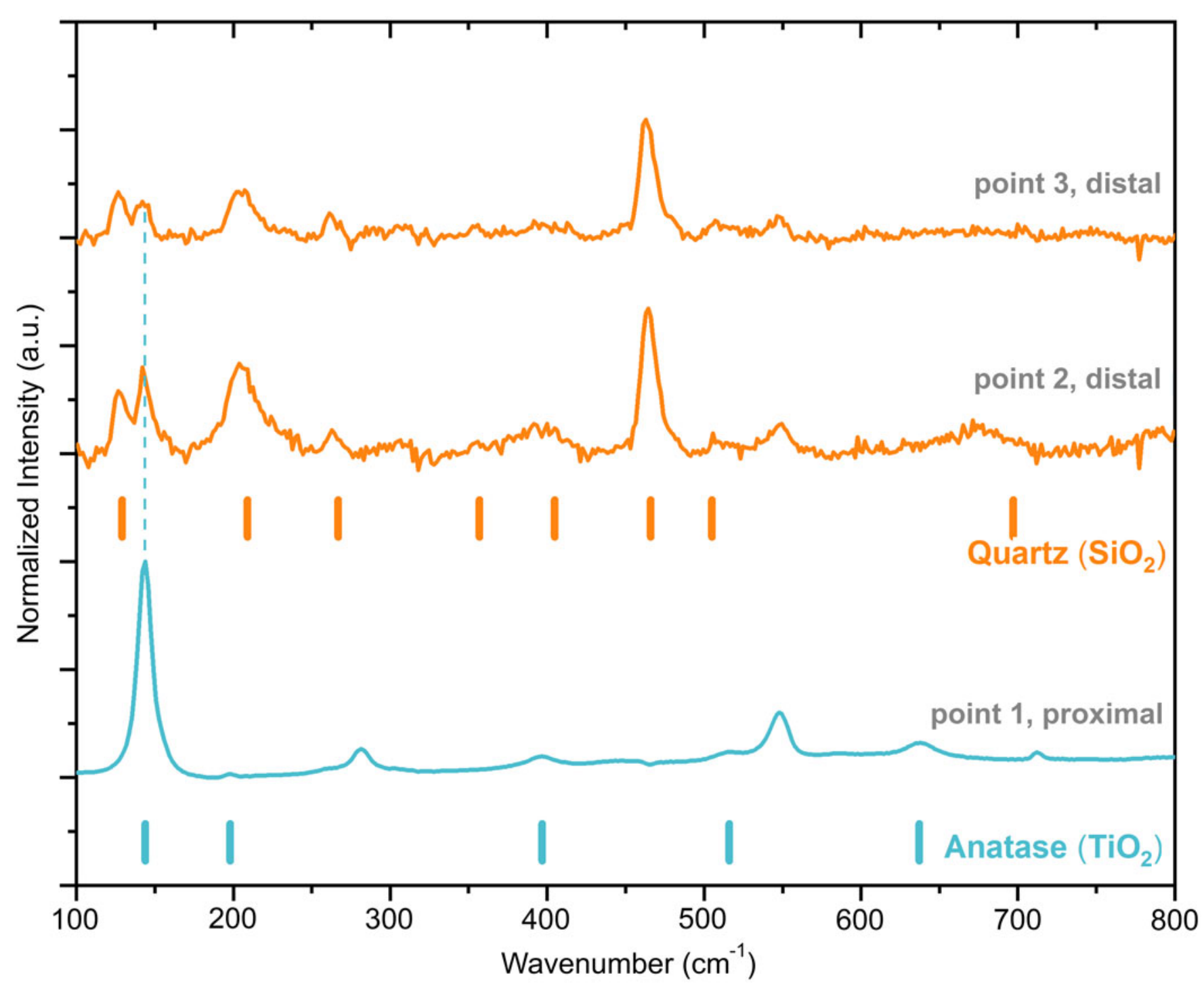

Figure 13. The wall composition of the Coniculus elegantis n. gen. n. sp. Moczydłowska in Moczydłowska et al., holotype specimen PMU 34737, illustrated in Figure 9, shown by the Laser-Raman point spectra from the wall surface in the distal and proximal portions and characteristic signatures of quartz and anatase minerals. The wall was siliceous and anatase derived from the burial environment. The blue and orange tick marks are the positions of strong $\mathrm{Raman}$ peaks of anatase $\left(\mathrm{TiO}_{2}\right.$, RRUFF ID: R060277) and quartz ( $\mathrm{SiO}_{2}$, RRUFF ID: R040031), respectively.

Remarks.-The new species is dissimilar to any previously described Ediacaran body fossils by its very regular shape of the conical wall, being straight along the long axis, and its original siliceous mineralogy of the cone.

Genus Fistula new genus Moczydłowska in Moczydłowska et al.

Type species.—Fistula crenulata n. gen. n. sp. Moczydłowska in Moczydłowska et al.

Diagnosis.—As for the type species.

Etymology.-From Latin fistula-ae, f., tube, pipe. Referring to the shape of tubular fossil that is formed by a cylindrical wall of a constant thickness and enclosing a free lumen.
Remarks.-This new monotypic genus differs from other Ediacaran macroscopic tubular fossils by having a genuinely cylindrical shape and a remarkably thick wall that is additionally double-layered and siliceous. The tube surface bears wrinkles and sutures marking segments, but is not annulated.

The new genus differs from Coniculus n. gen., which also has a double-layered wall with conspicuous veneer layer and is siliceous, by its cylindrical habit, crenulated surface, and segment sutures in contrast to the conical and smooth surface on the latter taxon.

Fistula crenulata new species Moczydłowska in Moczydłowska et al.

Figures $15-17$ 

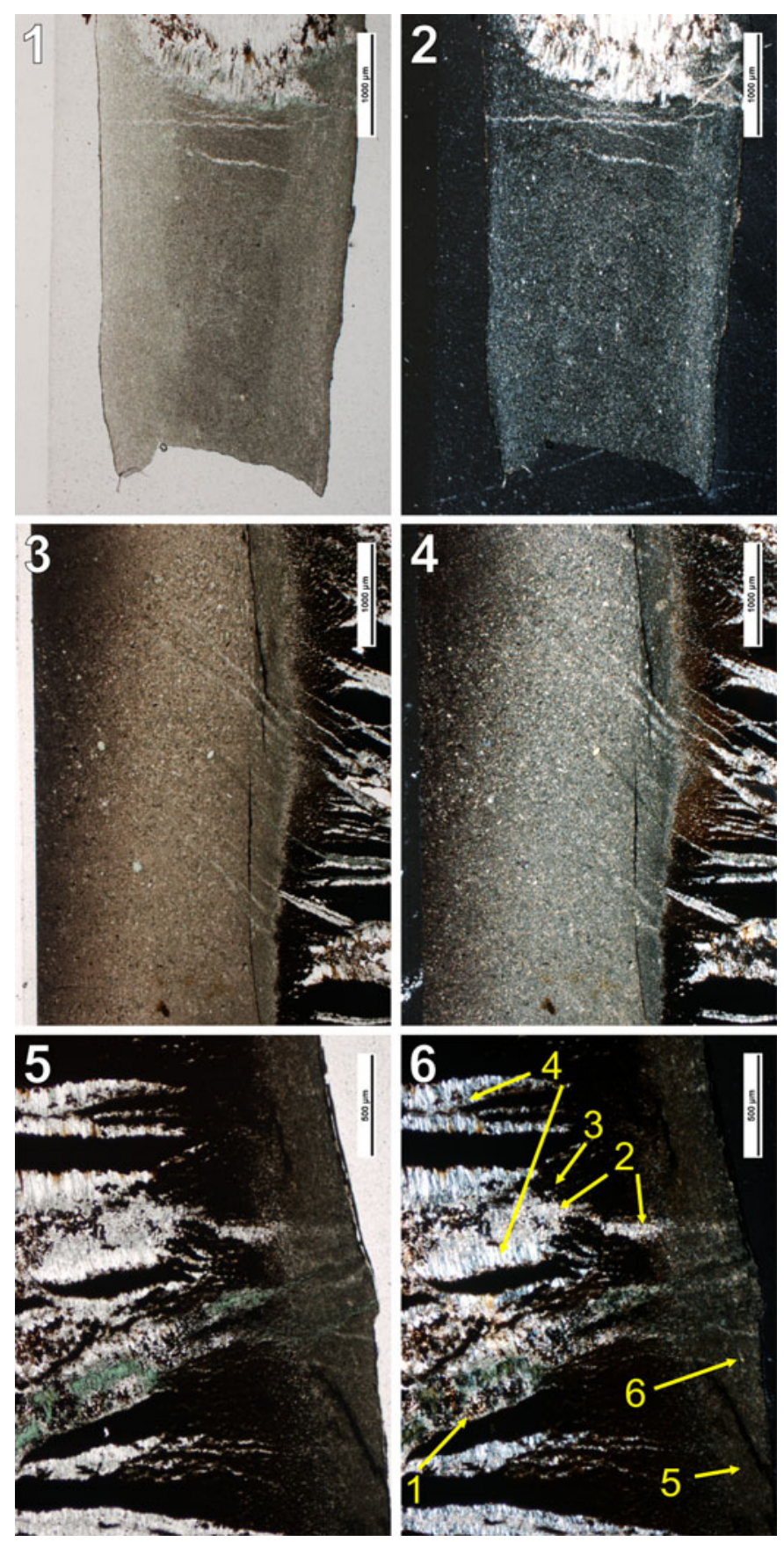

Figure 14. Petrographic thin section images of Coniculus n. gen. Moczydłowska in Moczydłowska et al. (PMU 34739), (1) parallel light, (2) crossed polarizers, and Fistula n. gen. Moczydłowska in Moczydłowska et al. (PMU $34744),(3,5)$ parallel light and $(\mathbf{4}, \mathbf{6})$ crossed polarizers, in longitudinal sections showing two layers of the wall and internal lumen infilled by host sediment. The wall layers are composed of microcrystalline phases dominated by silica (quartz, opal) and minor sheet silicates. The infilling of lumen is penetrated by coarse chalcedony veins. The outer veneer layer (dark line) is thin and compact and the inner layer (light gray band) is wide and microcrystalline. The aperture of Coniculus $\mathrm{n}$. gen. Moczydłowska in Moczydłowska et al. $(\mathbf{1}, \mathbf{2})$ shown in the upper edge of the specimen is infilled by elongated crystals of chalcedony. In Fistula $\mathrm{n}$. gen. Moczydłowska in Moczydłowska et al. $(\mathbf{3 , 4})$ lumen is shown at the right side, to the left is wall with internal and veneer layers, and a chip of host sediment attached on the surface, respectively. The opposite side of specimen in $(\mathbf{5 , 6})$, the lumen with chalcedony veins is at left side, then inner layer and veneer layers to the right. Numbers with arrows in yellow color in (6) refer to EMP EDS analyses shown in Figure 15.
Holotype.-Specimen PMU 34743, illustrated in Figure 16.1, 16.2; Paratype PMU 34748, illustrated in Figure 17.2, 17.4.

Diagnosis.-Macroscopic, cylindrical in shape body fossil with siliceous biomineralized, thick, double-layered wall, bearing faint wrinkles and narrow incised sutures (grooves) on the surface, which define segments, and having a hollow lumen that is circular in cross section. The wall surface is smooth, glossy, and slightly crenulate; the wrinkles and sutures are transverse to the tube long axis and relatively regularly distributed. The proximal portion of the tube is rounded and closed, but its apertural portion is open and circular in outline. The tube wall consists of an outer, very thin, veneer-like layer that has a distinctive compact texture; the inner layer is thicker and less dense in substance. The two layers of the wall are constant in their thicknesses along the tube length.

Description.-Tubular and cylindrical body fossil of constant diameter with hollow lumen, opened aperture, and closed proximal end (Figs. 16.1, 16.2, 17.2, 18.3, 18.4). The tube wall is double-layered and its radial symmetry is demonstrated by circular cross sections in undeformed specimens (Figs. 16.2, 17.7, 17.8). The tube, along its long axis from aperture to proximal end, shows morphological polarity (Figs. 17.2, 18). The tube total length in complete specimens is $50-73$ $\mathrm{mm}$; diameter 6-10 mm; wall thickness $2.0-2.3 \mathrm{~mm}$, including the outer veneer layer $0.1-0.3 \mathrm{~mm}$ in thickness; lumen diameter $3.3-4.0 \mathrm{~mm}$ (may be distorted up to $7.7 \mathrm{~mm}$ ). The two layers of the wall are perfectly aligned and constant in their thickness, but the outer veneer layer has a much denser texture than the inner and thicker layer (Figs. 16.2, 16.3, 17.8, $18)$. The tube segments that are delimited by the surface suture grooves are of similar length $(\sim 7.0 \mathrm{~mm})$ and distributed at $\sim 7.0 \mathrm{~mm}$ distances (Fig. 17.2, 17.4, 17.5). Surface crenulation and wrinkles are observed in some specimens (Figs. 16.1, 16.5, 17.1), and wrinkles are $1.0-3.0 \mathrm{~mm}$ in length and at intervals of $2.0-3.0 \mathrm{~mm}$, occasionally $7.0-8.0 \mathrm{~mm}$.

The internal features, seen only in CT images, are the knoblike structure at the bottom of the tube and the hollow lumen extending throughout the entire tube, although infilled by sediment in the lower portion (Fig. 18.2-18.4). Another specimen (PMU 34742), studied under RLM (Fig. 16.5) and by CT (Fig. 17.6), shows the fractured wall along the suture and demonstrates its constant thickness and sharp edges reflecting its rigidity, as well as sediment infilling the lumen.

The measurements of specimens compressed from their original circular cross sections are slightly distorted and given as ranges. The dimensions of specimens are: in holotype, the tube length is $14.0-15.0 \mathrm{~mm}$; tube diameter $7.0 \times 8.0 \mathrm{~mm}$; total wall thickness at cross section $2.0-2.25 \mathrm{~mm}$; wall outer veneer layer thickness $0.1 \mathrm{~mm}$ (RLM) or $50-100 \mu \mathrm{m}$ (STEM); tube lumen diameter $3.25 \times 4.0 \mathrm{~mm}$; individual segment length $\sim 7.0 \mathrm{~mm}$. The largest and most complete specimen (PMU 34749 ) has a tube length of $73 \mathrm{~mm}$; tube diameter $8.0-10.0$ $\mathrm{mm}$; wrinkles length $1.0 \mathrm{~mm}$; distance between wrinkles 2.0 $3.0 \mathrm{~mm}$; distance between segment sutures $\sim 7.0 \mathrm{~mm}$. In other, fragmented specimens, the tube partial length is $10.0-50.0$ $\mathrm{mm}$; tube width in side view $5.0-10.0 \mathrm{~mm}$ (compressed); tube diameter $6.0-9.0 \mathrm{~mm}$; wall inner layer thickness $2.0-2.3 \mathrm{~mm}$; 

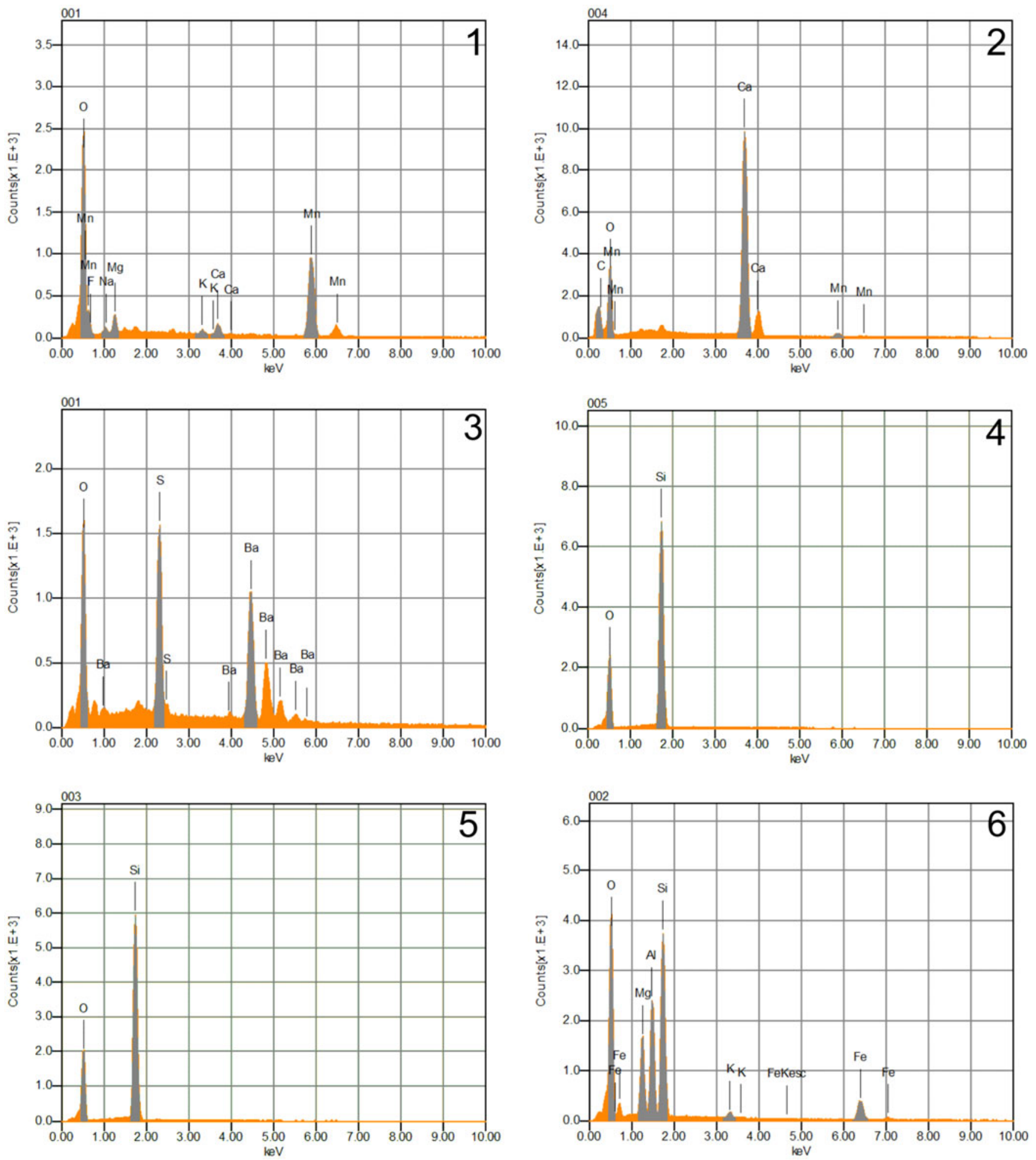

Figure 15. Analyses of elemental composition and mineralogy of Fistula $n$. gen. Moczydłowska in Moczydłowska et al. wall and lumen infilling minerals by a field emission electron probe microanalyzer equipped with energy-dispersive spectroscopy detector (EMP EDS) (1-6). (1-4) Minerals infilling the fossil lumen are diagenetic and comprise the first generation of Ca-carbonate (calcite) associated with Mn-oxide $(\mathbf{1}, \mathbf{2})$ and silica that are, in turn, partially replaced by the second generation of silica (chalcedony) (4), Ca-carbonate (calcite) and barite $(\mathbf{3})$. $(\mathbf{5}, \mathbf{6})$ The fossil wall is composed of pure silica $(\mathbf{5})$ with an admixture of a $\mathrm{Mg}$-Fe aluminosilicate, probably mixed-layer clay mineral $(\mathbf{5}, \mathbf{6})$.

wall outer veneer layer thickness $0.1-0.3 \mathrm{~mm}$; lumen diameter 2.15-7.75 mm; wrinkles length $1.0-3.0 \mathrm{~mm}$; distance between wrinkles $2.0-3.0 \mathrm{~mm}$ to $7.0-8.0 \mathrm{~mm}$ (when distorted); $(\mathrm{N}=15)$.
Etymology.-From Latin crenulatus- $a$, minutely crenate, crenulate, crenulated, and meaning of having an irregular wavy outline. Referring to a slightly crenulated cylindrical 


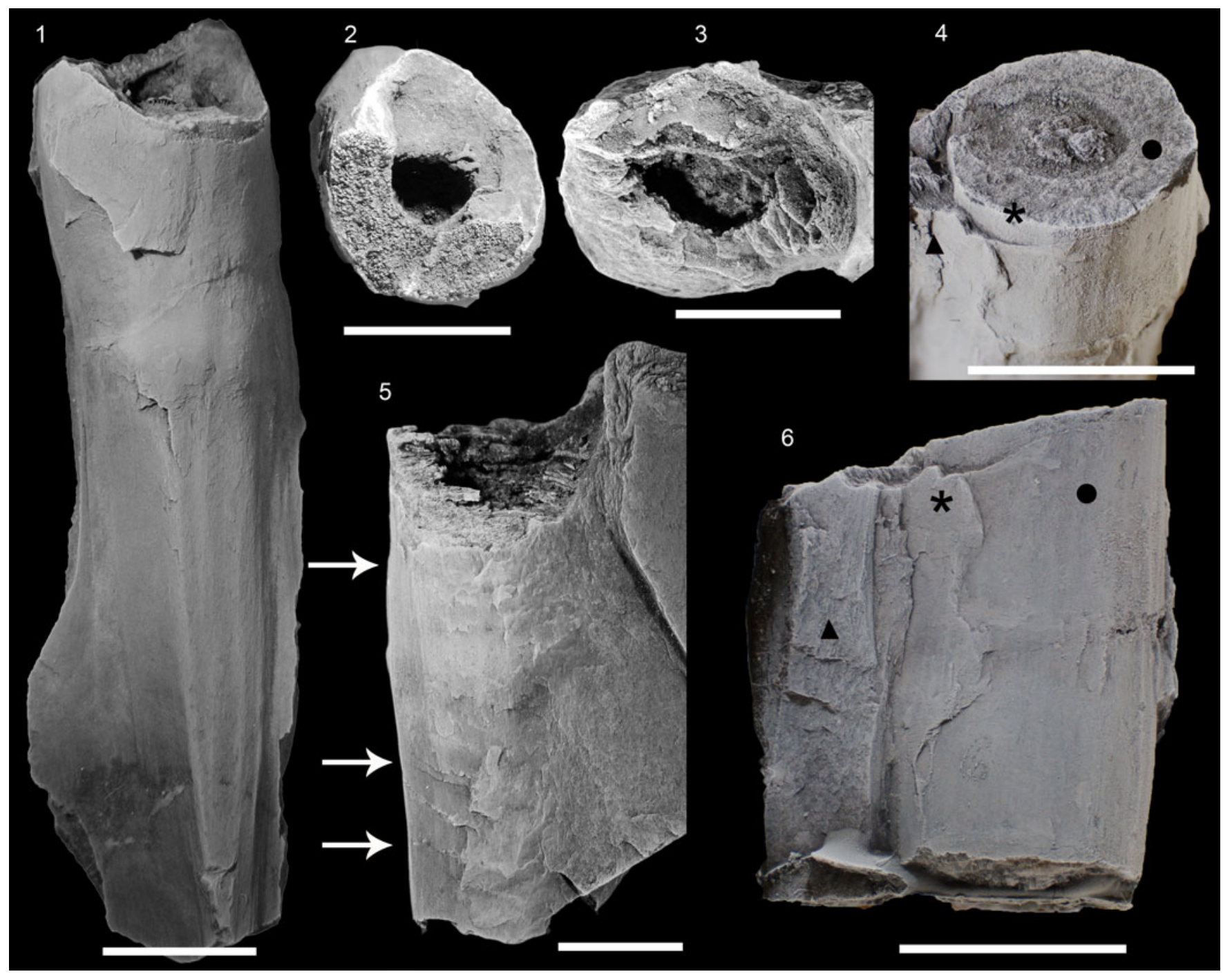

Figure 16. Macroscopic, mineralized cylindrical and segmented Fistula crenulata n. gen. n. sp. Moczydłowska in Moczydłowska et al. All are RLM images. (1, 2) Holotype specimen PMU 34743, side view in (1) with a sediment chip at left lower portion, and apertural view in (2) showing the sharp edge of the wall outer veneer layer and the thick inner layer around free lumen. $(\mathbf{3}, \mathbf{5})$ Specimen PMU 34744, showing the faint crenulation on wall surface and two wall layers; the sediment chip is attached to the wall surface on the right side and is clearly distinguishable from the veneer layer; white arrows point to the surface wrinkles. (4, 6) Specimen PMU 34741 showing the groove between the segments on the wall surface (6) and the two wall layers in cross section (4); the sediment is attached to the left side of specimen (black triangles) and easily recognizable from the specimen surface by peeling off $(\mathbf{4 , 6})$; black asterisks indicate outer veneer layer, and black dots the wall inner layer. Specimen cross sections demonstrate the radial symmetry of cylindrical exoskeletons. Scale bars $=5 \mathrm{~mm}$.

wall with perpendicular faint wrinkles on the wall surface ("minutely crenulated tube").

\section{Materials.-Seventeen 3-D preserved specimens.}

Preservation.-Specimens are slightly compressed to varying degrees and may show circular cross-section on one end and more oval on the other. However, their tubular walls are rigid and sharply fractured rather than showing ductile deformation. They were buried as lying on the bedding planes or obliquely entombed within the sediment layers, but probably not transported any significant distance. There are no signs of bottom currents or wave action in the host sediment, nor any sedimentary structures indicative of transport.

The holotype specimen is preserved with its proximal portion, but the apertural portion is likely broken away (Figs. 16.1,
16.2, 18). Two specimens (PMU 34749 and 34745) are undeformed and circular in cross section with their diameters $10 \mathrm{~mm}$ and $9 \mathrm{~mm}$, respectively (Fig. 17.1, 17.7, 17.8). The complete specimen that is preserved intact shows the maximum length and diameter known for the species (PMU 34749; Fig. 17.1).

Three preservational variants are observed among specimens attributed to Fistula crenulata n. gen. n. sp., reflecting their completeness or selective fragmentation, preservation state of being hollow inside or filled in with the host sediment, and being exposed from or partly entombed in the sediment with resultant obscuring of certain morphological features. Preservation variant 1 (Fig. 17.1, 17.2, 17.4; $\mathrm{N}=2$ ) is represented by complete, cylindrical specimens with well-preserved terminations and the surface crenulation, yet without clearly visible wall section and internal lumen. Preservation variant 2 

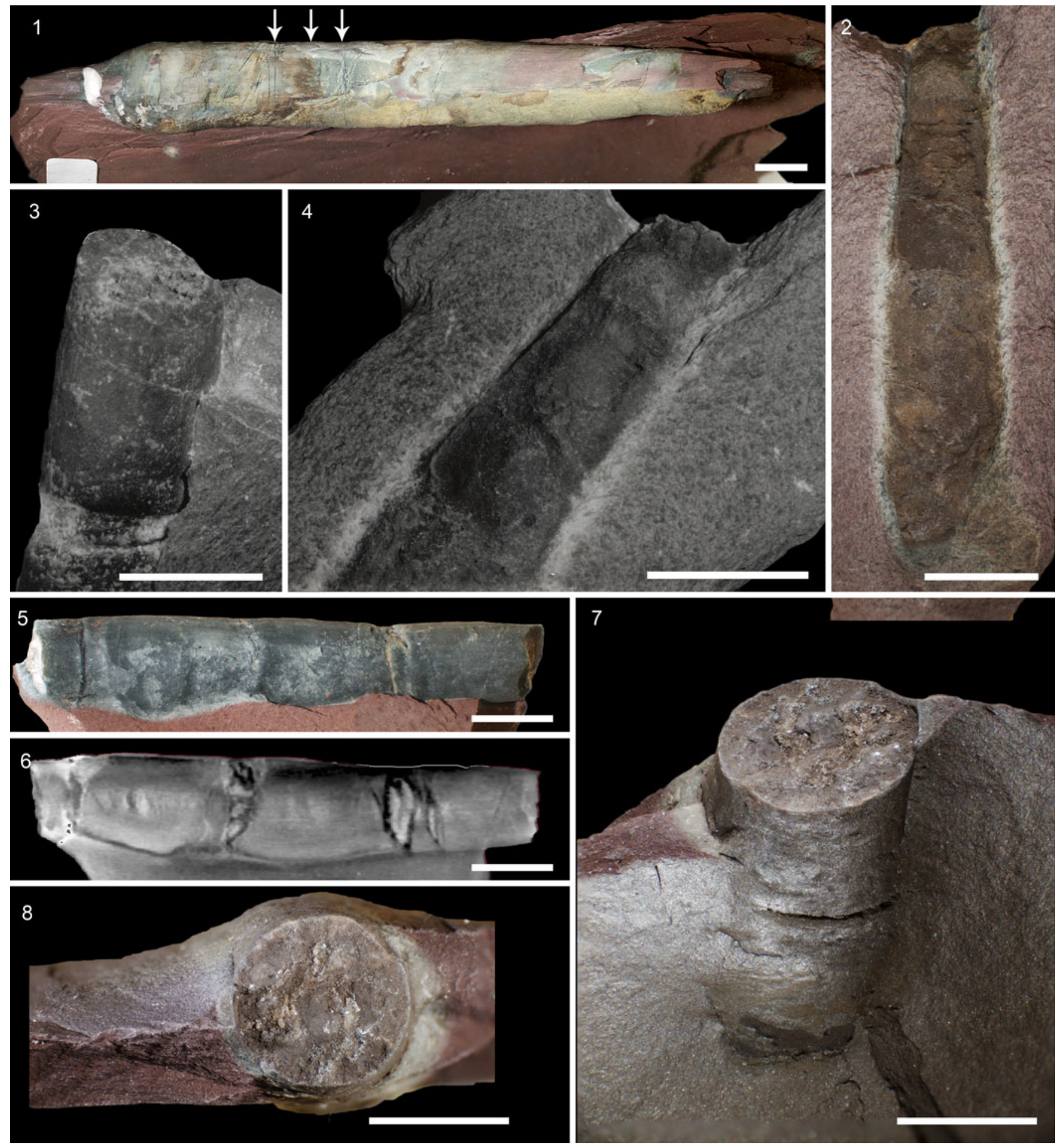

Figure 17. Macroscopic, mineralized, cylindrical, and segmented Fistula crenulata n. gen. n. sp. Moczydłowska in Moczydłowska et al. All are RLM images with the exception of CT image in (6). (1) Specimen PMU 34749, in major part exposed from the reddish sediment; the largest specimen with surface crenulation (faint wrinkles indicated by white arrows); circular cross section on the left end; covered by diagenetically crystallized quartz (white color). (2, 4) Paratype specimen PMU 34748 lying on the bedding plane and demonstrating longitudinal polarity; wall segments delimited by incised sutures (4); proximal end is rounded (2, bottom), and aperture is open (2, upper part). $(\mathbf{3}, \mathbf{5}, \mathbf{6})$ Specimen PMU 34742, showing cylindrical exoskeleton with segments $(\mathbf{5}, \mathbf{6})$, circular cross section (3), and constant wall thickness at fractures between the segments $(\mathbf{6})$; free lumen is infilled with sediment and visible under the fractured wall $(\mathbf{6})$ and at the apertural end covered by diagenetic quartz (5, left end, white in color). (7, 8) Specimen PMU 34745, undeformed and circular in cross section demonstrating its radial symmetry (8), lying on the bedding plane and partly exposed from the host sediment, with sediment layers bent around specimen (8); both wall layers are visible and lumen is infilled with sediment. Scale bars $=5 \mathrm{~mm}$ for all images. 
(Fig. 16.1-16.6; $\mathrm{N}=9$ ) is represented by fragmentarily preserved specimens that have only one original end, or none, because of breakage, but displays the double-layered wall in cross sections of the cylindrical tube, the central hollow lumen, and the wall surface. Preservation variant 3 (Fig. 17.7, $17.8 ; \mathrm{N}=6$ ) is similar in showing the specimens' surface, but only the outer veneer layer of the wall, whereas the remaining part of the tube interior is covered by or filled in with sediment, and the specimens are fragmented.

Wall construction and composition.-The wall construction differentiated into two layers by their alignment, texture, and thickness, observed in RLM and PLM, is also shown clearly in CT images. Internal feature of the knob-like element at the proximal end and possible compartments within the lumen, which could be also inferred from the presence of the surface sutures, are recognized (Fig. 17).

The wall of Fistula n. gen., observed in petrographic thin section in parallel light (Fig. 14.3, 14.5) and with crossed polarizers (Fig. 14.4, 14.6), is made of a mixture of opal and microcrystalline quartz and minor admixture of silicates. The outer veneer layer is thin and compact, as seen on both sides of a vertically sectioned specimen, and the inner layer is a mixture of opal and very fine microcrystalline quartz. The lumen is infilled by diagenetic minerals and fractured by secondary chalcedony veins (Fig. 14.3, 14.4, right side of images; Fig. 14.5, 14.6, left side of images). There is no sign of pseudomorphs, replication by other minerals, or surface encrusting. Detailed EMP EDS survey of the same thin section revealed that the wall is mostly composed of silica with an admixture of a $\mathrm{Mg}$-Fe aluminosilicate, probably mixed-layer clay mineral (Fig. 15.5, 15.6). In contrast to the wall, the lumen is filled in by first generation of Ca-carbonate (calcite) associated with Mn-oxide and silica that are, in turn, partially replaced by the second generation of silica (chalcedony), Ca-carbonate (calcite), and barite (Fig. 15.1-15.4).

In CT images of the holotype seen in a front view (Fig. 18.1), the material comprising the cylindrical wall is distinguished from the gray sediment by green artificial color that partly coats the specimen surface (Fig. 18.2) and extends below the proximal end of the specimen. The sediment is also infilling the oblique fracture of the specimen wall and is visualized by gray and blue color in Figure 18.4. The wall is thick, constant in thickness, rounded, and closed at the proximal end, and the central lumen also has a constant diameter (Fig. 18.2-18.4, olive color). The substantial total wall thickness is recognized along the length of the tube and is formed in a major part by the inner layer (Fig. 18.2-18.4). The inner layer of the wall is visualized in artificial green color and is thick and embraces the lumen, which is marked in olive color (Fig. 18.2-18.3). The outer veneer layer is depicted by gray color and the sediment infilling the lumen by olive color (Fig. 18.4). The sediment infilling in the lower portion of the lumen appears as transverse or slightly oblique, vertically stacked, band-like structures (Fig. 18.4, olive color) that may reflect compartments equivalent to tube segments (Fig. 17.4). The planes separating these structures may suggest pre-existing, morphological features and remains of the cross-walls that defined the compartments (chambers). The compartments

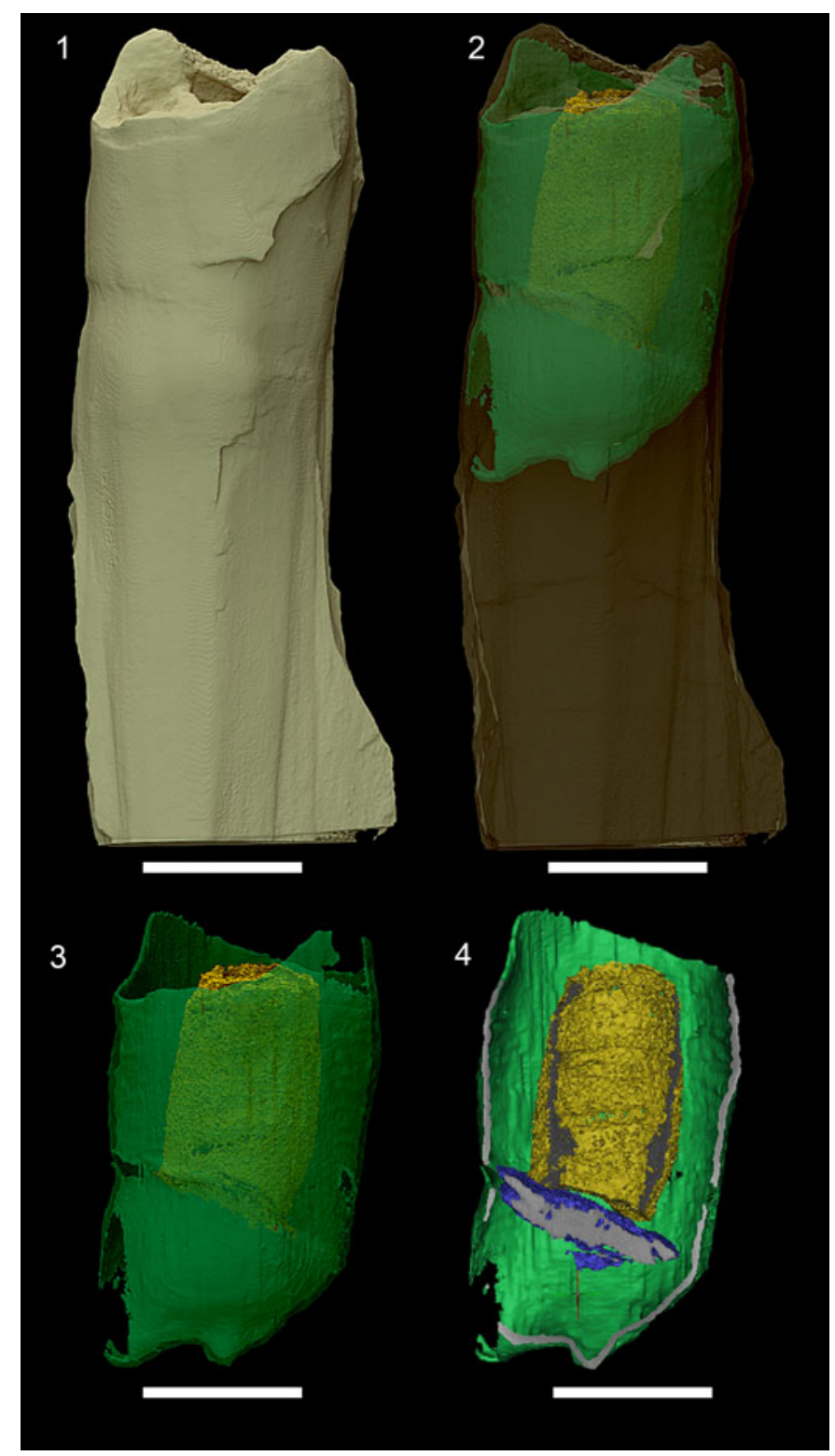

Figure 18. CT images of the Fistula crenulata n. gen. n. sp. Moczydłowska in Moczydłowska et al., holotype specimen PMU 34743, revealing the internal features of the tube wall and its two layers. Sediment partly covering the specimen in front view is gray in color in $(\mathbf{1}, \mathbf{2})$, as well as infilling the breakage of the wall, which is blue in color (4). The wall is marked by artificial colors: outer veneer layer is gray in $(\mathbf{3}, \mathbf{4})$; wall inner layer is green in (2-4). The knob-like structure is visible at the tube bottom $(\mathbf{3}, \mathbf{4})$ and broken portion of the veneer layer on the left side in (3). The central lumen infilled with the sediment appears as vertically stacked yellow bands in (4). Scale bars equal $5 \mathrm{~mm}$.

could correspond to the segments that are marked on the wall surface by sutures and partial cross-walls or semi-septa between compartments that would coincide with sutures. The oblique orientation of the band-like structures likely resulted from postmortem collapse or taphonomic deformation.

The outer veneer layer is shown as a thin layer in both of the longitudinal sections of the specimen (Fig. 18.4, gray line) and is missing on the side of the fractured wall (Fig. 18.4, lower left corner). The fracture demonstrates the sharp, brittle edges of the veneer layer (Fig. 18.3, gray color) in contrast to the underlying inner layer of the wall that appears less dense in texture. In 
another specimen (PMU 34742) under RLM (Fig. 17.5) and by CT (Fig. 17.6), the fractured wall along the suture on its surface shows a section of veneer layer and its constant thickness. By removing the image of sediment from the specimen surface (Fig. 18.1, 18.2), the veneer layer is seen in green artificial color (Fig. 18.3) and gray color (Fig. 18.3, 18.4). On the side of the proximal end of the tube, this layer shows clearly its uniform thickness in an open scar (Fig. 18.3, 18.4). The veneer layer is $100 \mu \mathrm{m}$ and the inner layer thickness in CT images transect view is $600-800 \mu \mathrm{m}$. The veneer layer covers the basal knob-like structure at the tube bottom (Figs. 18.3, 18.4) and confirms that this structure was a morphological entity and does not result from deformation. This structure is inferred to be the initial element in the construction of the wall by the young (or even larval) organism.

The chemical reaction to controlled dosing of $\mathrm{HF}$ on the exposed wall (specimen PMU 34746) was rapid corrosion of the surface, which indicates that $\mathrm{SiO}_{2}$ is dissolved from the wall. In contrast, the host sediment surrounding the specimen was not digested by HF. The chemical and mineralogical composition of the wall is revealed by Laser-Raman spectroscopy on two specimens and differs in intensity from to the quartz signatures of the host sediment.

Laser-Raman spectra were acquired at several points on the proximal, middle, and distal portions of the wall surface of specimen PMU 34752 (Fig. 19). The signatures are indicative of $\mathrm{SiO}_{2}$ in microcrystalline quartz phase. The strongest signatures were at the proximal portion where the wall surface is dark, smooth, glossy, and best preserved. An additional spectrum of $\mathrm{TiO}_{2}$ in the specimen distal portion (Fig. 19) is inferred to be derived from mineral crystals in the burial environment, as in other studied taxa.

Multiple Laser-Raman point spectra were acquired on the exposed surface of the wall from another specimen (PMU 34750; Fig. 20.1). The sediment directly entombing the specimen was examined, as well as the sediment overlying this stratigraphic horizon, for independent comparison of the sediment composition and diagenetic alteration (Fig. 20.2, 20.3). The specimen fragment is preserved with its proximal end covered in part by sediment, its more distal portion sectioned by fracture, and the veneer layer chipped-off and continually extending above it. The tube lumen is infilled by host sediment, but without any sign of quartz recrystallization. The specimen length is 20 $\mathrm{mm}$, diameter $4.75-6.75 \mathrm{~mm}$, inner layer thickness $1.25-1.50$ $\mathrm{mm}$, and veneer layer thickness $0.2-0.3 \mathrm{~mm}$.

Several spectra $(N=4)$ from the thick inner layer on the cross section of the wall show strong quartz and weak anatase signatures (Fig. 20.1), and the exposed by breakage veneer layer $(\mathrm{N}=4)$ shows similar signatures of both quartz and anatase (not illustrated). Additionally, a signature of carbonaceous material in disordered band (D-band) is observed, which may suggest carbonaceous material preserved within the mineralized wall, as it was in Anulitubus n. gen.

The spectra of the oxidized, red, thin-bedded mudstone entombing the specimen shows a weak signature of quartz, strong of hematite, weak of anatase, and carbonaceous material in the D-band ( $=3$; Fig. 20.2). This quartz signature is significantly weaker than in the specimen wall (Fig. 20.1). The sediment composition examined by XRD spectra of the sample

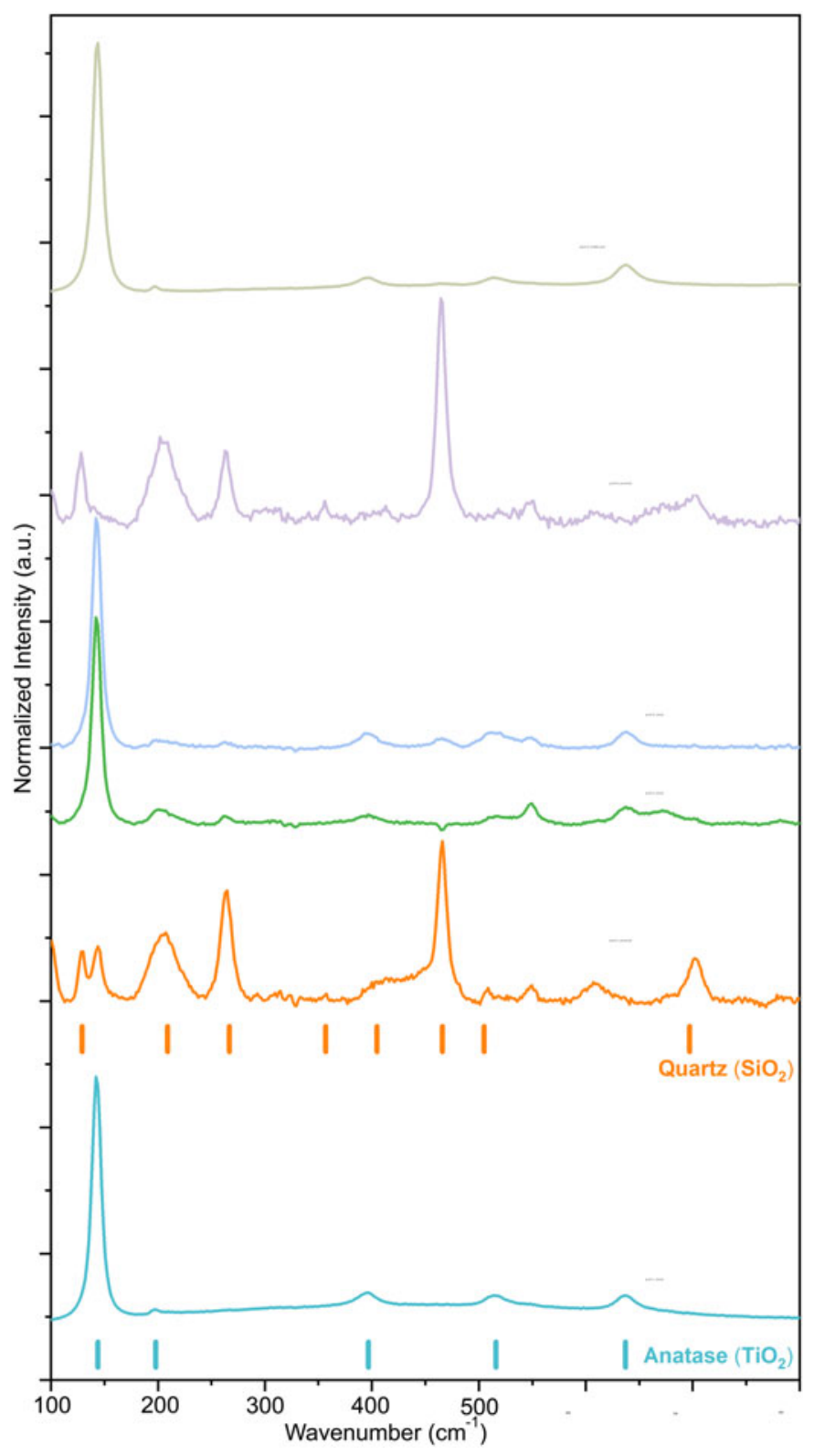

Figure 19. Wall composition of Fistula crenulata n. gen. n. sp. Moczydłowska in Moczydłowska et al. revealed by the Laser-Raman spectra acquired on the wall surface in several points on different portions of specimen PMU 34752, and showing the signatures of quartz and anatase minerals. The wall is siliceous in the quartz microcrystalline phase, and anatase is a contaminant from the sediment. The blue and orange tick marks are the positions of strong Laser-Raman peaks of anatase $\left(\mathrm{TiO}_{2}\right.$, RRUFF ID: R060277) and quartz $\left(\mathrm{SiO}_{2}\right.$, RRUFF ID: R040031), respectively.

from the same bed documents the content of quartz, muscovite, feldspars, kaolinite, hematite, leucite, and smectite (Fig. 21; Supplementary Data). Quartz, muscovite, and feldspars are detrital and other minerals are diagenetic, including minor diagenetic microcrystalline quartz. The carbonaceous material depicted by D-band in the spectra is inferred to be derived from kerogen preserved within the sediment.

The difference in the intensity of quartz signatures between the specimen wall (strong) and the sediment (weak signature, low intensity) supports the interpretation that the wall was primarily silicified before the sediment was diagenetically altered, 

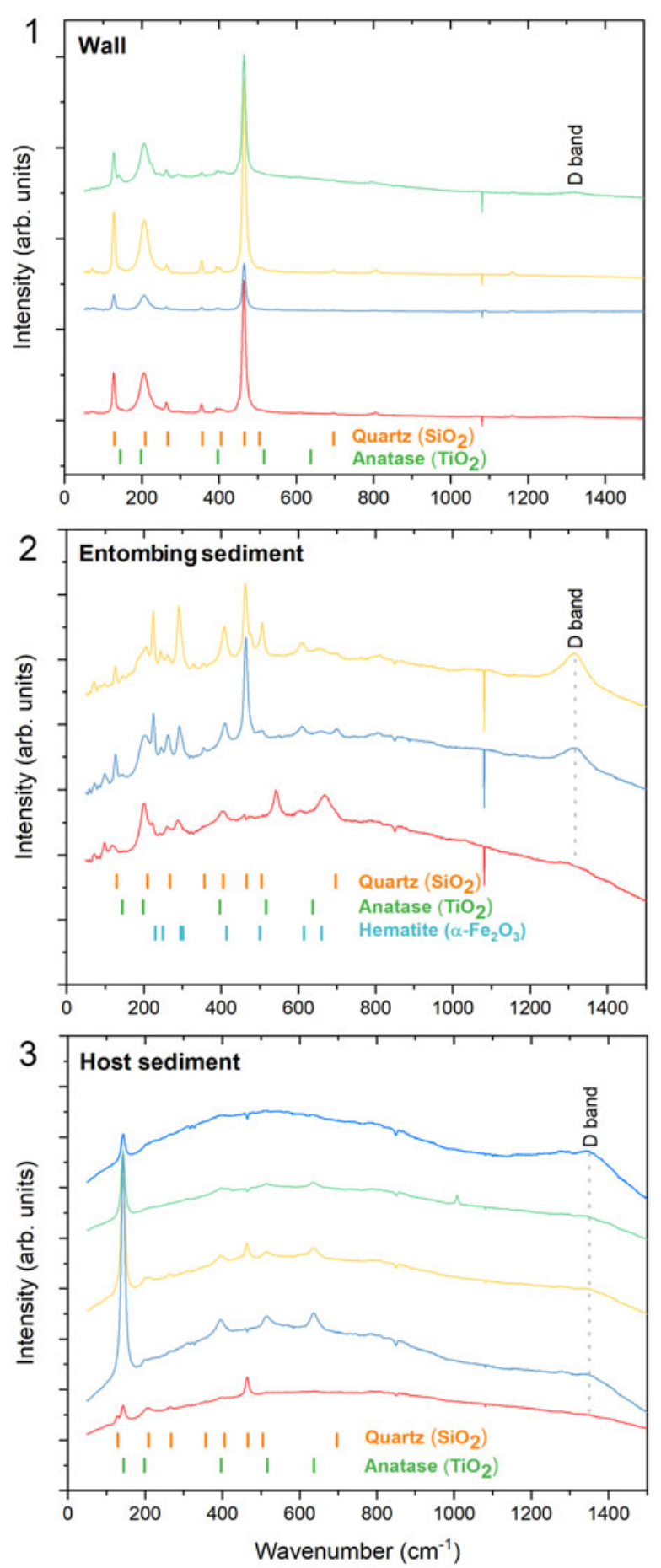

Figure 20. The Laser-Raman spectra, for comparison of mineralogical composition and differentiation of primary mineralogy of the fossil, acquired (1) on the wall of Fistula crenulata n. gen. n. sp. Moczydłowska in Moczydłowska et al., specimen PMU 34750, (2) on the entombing sediment around the specimen, and (3) on another sample of host sediment a few meters above the specimen. The strong quartz spectra of the wall $(\mathrm{N}=4)$ is different than the weak spectra in the entombing $(\mathrm{N}=3)$ and overlying sediments $(\mathrm{N}=5)$, showing the primary siliceous skeleton of the fossil in quartz microcrystalline phase. The signatures of anatase and hematite minerals are from the sediment and contaminant in the fossil. The carbonaceous material in disordered D-band indicates the organic matter admixture in the fossil wall and its presence as disseminated organic matter in the sediments. The green and orange tick marks are the positions of strong Laser-Raman peaks of anatase ( $\mathrm{TiO}_{2}$, RRUFF ID: R060277) and quartz $\left(\mathrm{SiO}_{2}\right.$, RRUFF ID: R040031), respectively; blue tick mark is for hematite.

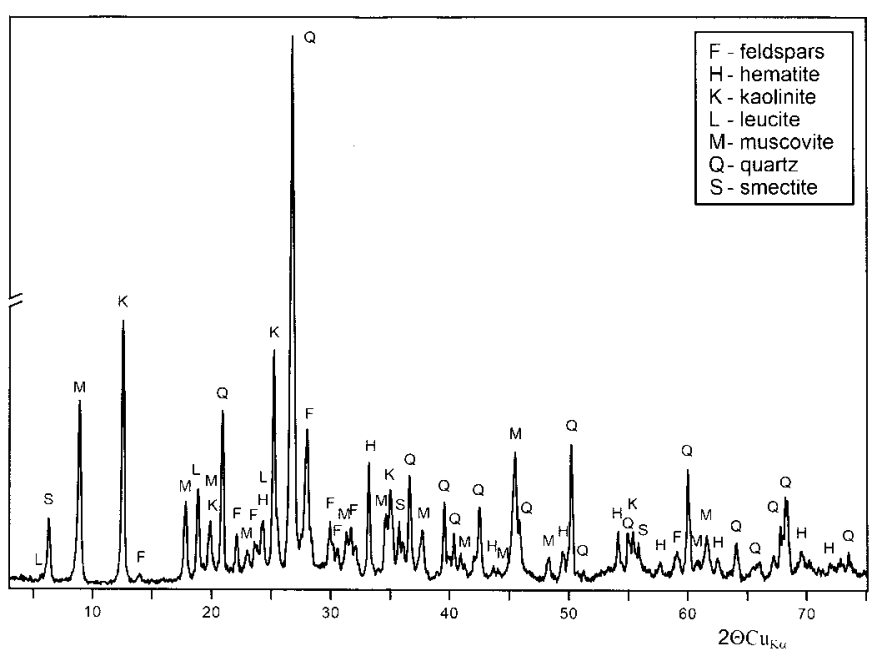

Figure 21. Mineralogic composition of the sediment entombing the fossils examined by X-ray diffraction (XRD). Red, thin-bedded mudstone is composed of detrital quartz, muscovite, and feldspars. Other identified minerals are diagenetic.

and authigenic quartz, hematite, kaolinite, and other diagenetic clay minerals, as well as anatase, were formed in the rock cement. The original siliceous wall may have been diagenetically "enhanced" in its composition, but it was not replicated.

The Laser-Raman spectra acquired in several points $(\mathrm{N}=5)$ from an additional sample of gray micaceous mudstone of the host sediment, which lies $\sim 15 \mathrm{~m}$ above the fossiliferous interval, showed a weak signature of quartz, strong of anatase, and the carbonaceous material signature in the D-band (Fig. 20.3). The quartz signature is similar to that in the other sample of host sediment, but weaker than in the specimen wall. The presence of carbonaceous material, and the absence of carbonates or calcareous cement in the sediment of the Innereva Member as a possible source of element $\mathrm{C}$, indicate a biotic remnant of the organic matter. Disseminated organic matter is expected to be preserved in this sediment because organic-walled microfossils (acritarchs and filamentous cyanobacteria) and organic macroscopic Palaeopascichnus are recorded in the Indreelva Member (Jensen et al., 2018; Fig. 2; unpublished microfossils). In studied Laser-Raman points in both the specimen and host sediments, as in the XRD analysis, there is no signature of calcareous minerals $\left(\mathrm{CaCO}_{3}\right)$, which evidently precludes the possibility of its existence in the fossil wall.

Remarks.-The new species differs from other Ediacaran tubular taxa by its double-layered wall construction, the knob-like element at the proximal end, and the presence of sutures on the wall surface.

\section{Metazoan affinity and taxonomic comparisons}

Phenotypically, the new taxa described manifest a range of features consistent with metazoan affinity: macroscopic sizes $(0.5-$ $7.0 \mathrm{~cm})$, cylindrical and conical shapes, annulated or segmented structure with smooth to crenulate surface ornamentation, single- or double-layered skeletal wall, radial symmetry, and longitudinal polarity, including closed proximal versus open apertural (oral) ends. There was also clearly staged skeletal 
accretion and increase in diameter from a cup or knob-like proximal initial skeleton in Anulitubus n. gen and Fistula n. gen., or a simple cone in Coniculus n. gen. The variation in skeletal morphology and complexity observed between these taxa is comparable with modern marine benthic organisms, such as cnidarians and lophophorates, as well as vermiform animals and tubular annelids (especially polychaetes), or even bryozoans. However, individual morphological elements observed in new taxa, their overall body habit, and some structural similarities exist with Ediacaran body fossils such as Cloudina, Sinotubulites, Conotubus, Multiconotubus, Gaojiashania, and Shaanxilithes. All the latter taxa possessed either organic integument or mineralized skeletons, and have been interpreted as possible representatives of currently extant phyla (Grant, 1990; Cai et al., 2010, 2014, 2015; Cortijo et al., 2010, 2015; Zhuravlev et al., 2012, 2015; Wood et al., 2017, 2019; Schiffbauer et al., 2020; Shore et al., 2020; Yang et al., 2020).

Cloudina has nested funnel-like elements with high Mg-calcite content (Grant, 1990; Zhuravlev et al., 2012, 2015; Cai et al., 2014; Cortijo et al., 2015; Wood et al., 2017), as preserved in carbonate rocks, and was interpreted as biomineralized exoskeleton from the total-group cnidarians, and thus crown-eumetazoans and non-bilaterian (Wood et al., 2019; Shore et al., 2020). This was based on a combination of morphological characteristics, growth and reproduction patterns, as well as microstructure of the tube, and inferred paleoecology. Yet, Cloudina has also been compared with serpulid worms that are polychaetes in the Phylum Annelida (Hua et al., 2005; Cai et al., 2014), but this affiliation has been questioned and Cloudina was considered to be a cnidarian (Zhuravlev et al., 2012; Warren et al., 2017). This was concluded because of the microstructure of Cloudina and the pattern of budding in asexual reproduction that are characteristic of cnidarians (Zhuravlev et al., 2012). The multiple (polytomous) branching of tube and attachment structures in Cloudina, and cloudinomorphs in general, were supporting the cnidarian and non-bilaterian affinity (Shore et al., 2020). Alternatively, Cloudina and new cloudinid Zuunia have been further interpreted to be originally organic and non-mineralizing stem-group annelids (Yang et al., 2020). Other cloudinomorphs, exemplified by Saarina Sokolov, 1965, emend. Selly et al., 2020 and Costatubus Selly et al., 2020 , that were inferred to have been organic in original composition and preserving internal cylinders representing guts have been placed among the stem-annelids, and thus bilaterians (Schiffbauer et al., 2020; Selly et al., 2020). These opposing interpretations may be reconciled if cloudinomorphs show convergent morphology of funnel-stacked elements in tubes and represent polyphyletic origins (Shore et al., 2020). With regards to the new genus Anulitubus, the presence of morphological elements of segments, although ring-like and not funnel-like in the tubular body, is demonstrably a metazoan feature.

Sinotubulites is a multilayered cylindrical fossil interpreted to have been a biomineralizing organism with a probable animal affinity (M. Chen et al., 1981; Z. Chen et al., 2008; Cai et al., 2015) or of uncertain affinity (Wood et al., 2017). Its morphological similarity to organic-walled Corumbella has been recognized, and the latter taxon inferred to be a scyphozoan cnidarian (Van Iten et al., 2014), with Wood et al. (2019) positing that Sinotubulites is a mineralized counterpart of Corumbella Hahn et al., 1982, thus supposedly cnidarian. The double-layered wall in new conical Coniculus n. gen. and cylindrical Fistula n. gen. is present and is consistent with metazoan affinities.

Conotubus is tapering along its length and has nested funnel-shaped elements, and was grouped with Cloudina and Sinotubulites to constitute the family Cloudinidae (Hua et al., 2007; Cai et al., 2011), and thus related to cnidarians as Cloudina was recognized (Wood et al., 2017, 2019; Shore et al., 2020), or Cloudina as newly attributed to stem-annelids (Yang et al., 2020). Regardless of the closer phylogenetic relationships, Conotubus is accepted to be metazoan. Comparably, the overall conical body habit and wall layering structure of Coniculus n. gen., although without segmentation, is shared with metazoans.

Multiconotubus has a multilayered, cone-in-cone wall structure and is diagnosed as a conical biomineralizing organism with "apical" end closed and open aperture (Cai et al., 2017). The fossil is 3-D preserved and diagenetically phosphatized (Cai et al., 2017, 2019), but its primary mineralogy and possible affinity have not yet been determined. This taxon resembles Coniculus n. gen. morphologically by conical shape and layered wall, and both are considered metazoans.

Gaojiashania is preserved as carbonaceous compressions of tubes with characteristic circular rings (Cai et al., 2010). This taxon has been variously interpreted as worm (Hua et al., 2004), or tubular metazoan in general (Weber et al., 2007). The segmented flexible tube structure has been compared specifically with modern siboglinid polychaetes (Cai et al., 2013). The fossil was originally organic or lightly mineralized (Hua et al., 2004; Cai et al., 2010, 2012, 2013; Smith et al., 2016), although without indication of its primary mineralogy.

The segments of the tubular body in Anulitubus n. gen. resemble the morphology of Gaojiashania, which is however non-mineralized.

Shaanxilithes is a ribbon-shaped and annulated or corrugated compression fossil (Hua et al., 2004; Shen et al., 2007; Cai et al., 2010) that may be metazoan in origin (Tarhan et al., 2014). Its organic composition has been established by environmental SEM EDS spectra and elemental mapping and LaserRaman spectroscopy from specimens preserved in a variety of sediments, including dolostone, siltstone, and phosphatic shale (Meyer et al., 2012; Tarhan et al., 2014). This taxon body annulation may resemble the surface of Fistula n. gen.

In summary, the terminal Ediacaran body fossils are recognized as metazoans based on their morphology, symmetry, wall construction and structure, and inferred benthic mode of life and paleoecology (Cai et al., 2011, 2012; Wood, 2011; Zhuravlev et al., 2012, 2015; Wood and Curtis, 2015; Penny et al., 2017; Wood et al., 2017, 2019; Schiffbauer et al., 2020; Shore et al., 2020; Yang et al., 2020). By the same characteristics of having complex morphology, comparable individual features, radial symmetry and polarity, and structure of mineralized wall, the new taxa represent a metazoan grade of organisms, as was their mode of life within the benthos.

\section{Skeletal biomineralization}

We considered a potential non-mineralized organic construction of the new fossils' walls or their diagenetic mineralization versus primary biomineralization. As aforementioned under each 
taxon, the lack of even accessory elements $\mathrm{Ca}$ or $\mathrm{P}$ in the walls and the host sediment excluded potential diagenetic replacement by silica of calcareous or phosphatic skeletons. The only exception is the diagenetically induced, secondary calcareous mineral in the infilling of lumen of Fistula n. gen. (Figs. 14, 15). However, this is clearly distinguished from the wall mineralogy, which is siliceous with an admixture of aluminosilicate clay mineral. There is no record of any significant pyrite crystallization in the fossils, as it would be in taphonomic pyritization of organic walls by bacterial decay (seen in SEM images, but not illustrated). Most significant is the very different degree of host-rock early diagenetic silicification or admixture of silicate clay minerals, which is low and not exceeding the common content of $\mathrm{SiO}_{2}$ in typical siliciclastic rocks. To the contrary, as shown by the series of Raman spectroscopic, petrographic, and SEM- EMP EDS analyses, the fossils' walls are siliceous and differentiated from the sediment (Figs. 14, 15, 21), thus supporting primary biomineralization. The diagenetic history of the succession that contains the fossils and in a regional scale provides no evidence for the diagenetic silicification of strata and taphonomic alteration of fossils. The lesson is learned from the interpretations of biomineralized versus primary organic construction of Cloudina and some other cloudinomorphs, which were thought to be the earliest metazoans with biomineralized calcareous skeletons (Grant, 1990; Zhuravlev et al., 2012; Cai et al., 2014; Cortijo et al., 2015; Wood et al., 2017) and turned out to be originally organic (Schiffbauer et al., 2020; Yang et al., 2020). Expectedly, the next finds of described fossil taxa will provide additional preservation modes to test the interpretation favored here.

Our microscopic, petrographic, spectroscopic, and geochemical analyses all infer the presence of primary biomineralized silica in the skeletal walls of the new Digermulen fossils. The additional supporting evidence is also the lack or only accessory admixture of digenetic silicate clay minerals in the host matrix, as well as the absence of any chert nodules, intrusive siliceous layers, or veins. There is likewise no indication of mineral dissolution (mobilization), solution migration, or recrystallization (Dallmeyer et al., 1989; Rice et al., 1989; Meinhold et al., 2019a), and the fossils themselves are not diagenetically replaced or encrusted.

Biomineralization is biologically induced or organic matrixmediated mineralization (Lowenstam, 1981; Lowenstam and Weiner, 1989), and the first type is characteristic of single-celled organisms and the second of eukaryotes (Veis, 2003). In forming of the mineral phase by organisms, the mineral is sequestered from the aqueous environment depending on temperature, $\mathrm{pH}$, water chemistry, and ion saturation (Veis, 2003). The process of silicification in organisms always proceeds in confined spaces in which organic membranes or extracellular matrices govern the precipitation of biosilicas (Perry, 2003). The precipitated biosilicas are amorphous and silicified organisms have complex structural features (Perry, 2003). The complexity of walls containing organic matter in studied taxa is in accord with the inferred biomineralization, which is suggested from the chemical elemental (STEM- EMP EDS) and primary mineral (petrography, LaserRaman signatures) composition of the wall.

Laser-Raman spectra show markedly more intense quartz peaks in the fossils (a typical diagenetic transformation phase of originally precipitated opaline silica) versus host sediment samples. These spectra indicate that the fossils were silicified before the sediment was lithified and its detrital quartz grains and cement could be diagenetically altered and affect the buried fossils (Fig. 19; Supplementary Data). Differentiation between the fossil versus host sediment mineral signatures and intensity (mineral concentration) if containing the same mineral, allows recognition of the fossil primary composition (Cai et al., 2012; Meyer et al., 2014; Schiffbauer et al., 2014; Muscente et al., 2015; Shang et al., 2018).

These geochemical-spectroscopic methods of determining the material composition have been applied in studies of both mineralized and organic fossils of Ediacaran and other ages and for distinguishing in-life from taphonomic mineralization (Schopf et al., 2005; Cai et al., 2012; Meyer et al., 2012, 2014; Moczydłowska et al., 2014; Schiffbauer et al., 2014; Tarhan et al., 2014; Muscente et al., 2015; Pruss et al., 2015, 2018; Shang et al., 2018). Laser-Raman spectroscopy is a nondestructive optical method that provides the information to identify the chemical composition of fossils and allows their mineral identification (Kudryavtsev et al., 2001; Schopf et al., 2002, 2005; Wacey, 2009; Olcott Marshall and Marshall, 2015). In the present case study, this method supports biomineralization, as does the petrography.

Independently of geochemical analyses, we thoroughly reviewed the diagenetic history of the host sediment in respect to fossil taphonomy and mode of preservation. The tectonic and diagenetic changes associated with the Caledonide orogeny had relatively limited influence on the studied sedimentary succession (Dallmeyer et al., 1989; Rice et al., 1989; Meinhold et al., 2019a) and the constituent fossils. Mineral composition of shales by XRD analysis determined largely quartz and muscovite, with subordinate chlorite, plagioclase, and hematite. The detrital quartz grains are modified to elongate shape produced by cleavage-forming processes associated with low-grade metamorphism and tectonothermal activity, age-constrained to 440.2 \pm 9.4 Ma (Dallmeyer et al., 1989). This tectonothermal alteration at the stage of diagenesis transitional to anchizone $\left(\sim 200^{\circ} \mathrm{C}\right)$, together with pressure-related dissolution of micas but without mobilizing silica, precluded silicification of the sediment. There is no evidence of recrystallization or penetrative migration of any mineral solutions. These conditions were key for preserving the primary mineralogy of the fossils and preventing its replication. The shale from the upper Indreelva Member analyzed by XRD consists of $71 \%$ phyllosilicates (mainly illite), $18 \%$ quartz, $10 \%$ feldspar, and $1 \%$ other minerals (Meinhold et al., 2019a). This analysis shows a relatively low content of quartz and does not support the possibility of syngenetic or diagenetic silicification. Our XRD study of laminated mudstone entombing the new fossils in the lowermost Indreelva Member also documents the presence of quartz, kaolinite, muscovite, feldspars (K-feldspar), hematite, leucite, and smectite, and possibly a zeolite group of minerals (Fig. 21; Supplementary Data). This composition is typical of fine-grained siliciclastic rock comprised of detrital, diagenetic, and weathered aluminosilicates (phyllosilicates), and detrital and authigenic quartz (Supplementary Data).

The mineralogical and diagenetic features of the host sediment are congruent with the interpretation that the new fossils 
preserved primary mineralogy. Comparably, the organic-walled metazoan Sabellidites, macroscopic filamentous vendotaenids, and microscopic unicellular acritarchs preserved in the formation (Farmer et al., 1992; Högström et al., 2013; Jensen et al., 2018; unpublished data on acritarchs) remained organically preserved, thus independently attesting against the sediment syngenetic or diagenetic silicification. There could not be selective permineralization of one type of fossil. The casts and molds of co-occurring Palaeopascichnus show no sign of diagenetic silicification or other re-mineralization (Jensen et al., 2018), and this state of preservation is in contrast to, and also supports, the primary mineralogy of the new fossils.

Diagenetic to the lowermost metamorphic grade of alteration and without remineralization or recrystallization affected the sediment long after (135 and $175 \mathrm{Ma}$ ) the studied organisms were buried ca. $575 \mathrm{Ma}$. They were originally resistant, threedimensional, and mineralized by primary silica. These organisms were the earliest silica biomineralizing macroscopic organisms that formed skeletons.

\section{Environments facilitating silica biomineralization}

Accepting our age estimates, biogenic skeletal silicification would appear to have been the first step in animal biomineralization at ca. 575 Ma. Previously, aragonite-calcite biomineralization was inferred to appear at ca. $550 \mathrm{Ma}$ (Wood et al., 2017), with phosphatization emerging shortly after $541 \mathrm{Ma}$ (Erwin et al., 2011; Erwin and Valentine, 2013). However, the nominal taxon Cloudina and some other cloudinomorphs, among those animals interpreted to biomineralize ca. $550 \mathrm{Ma}$, have been revised as organic and non-biomineralized but taphonomically altered into various modes such as phosphatic, organic/pyritic, calcareous, limonitic/pyritic, and siliceous preservations (Schiffbauer et al., 2020; Yang et al., 2020). Namacalathus Grotzinger et al., 2000 and Namapoikia Wood et al., 2002 remain as possible calcareous skeletal organisms in the terminal Ediacaran (Grotzinger et al., 2000; Wood et al., 2019). The initial diversification of skeletonized animals then considered has been variously attributed to changing oceanic chemistry, redox conditions, and predation (Bengtson, 2004; Wood, 2011), as well as based on the record of calcareous fossils (Cui et al., 2016; Schiffbauer et al., 2016; Bowyer et al., 2017; Wood et al., 2017, 2019). No predation is evident at that time or in the Ediacaran Period (Narbonne, 2005; Gibson et al., 2019). Silica biomineralization has been posited in sponge spicules (Sperling et al., 2010), but not yet considered a factor in integument of metazoan body fossils in this developmental transition, but it might also had been environmentally triggered by the ready availability of silica. The concentration of silica in cold seawater is higher, facilitating sequestration into siliceous skeletons (Perry, 2003), and such conditions existed during the Gaskiers glaciation (580 Ma) and shortly after, where biomediated silica uptake may have been more efficient. Indeed, previous studies have determined that oceanic silica concentrations were unusually high in the Precambrian (Siever, 1992; Maliva et al., 2005; Konhauser et al., 2007; Tarhan et al., 2016) and promoted chert precipitation in the absence of hydrothermal input (Shen et al., 2011; Ramseyer et al., 2013; Dong et al., 2015; Shang et al., 2018; Penman and Rooney, 2019) or biogenic mediators (e.g., siliceous sponges, foraminiferans, radiolarians, diatoms, and chrysophytes, all of which appeared much later). Early Ediacaran cap chert formation in Africa and Mongolia has been linked to the global post-Marinoan deglaciation and demonstrates the oversaturation of silica in the ocean and perturbations in the silica cycle, as was in the carbon cycle (Penman and Rooney, 2019), at least regionally. Similar conditions might therefore have existed in the post-Gaskiers deglaciation interval, which likewise evinces carbon cycle disturbances (Halverson et al., 2010; Zhou et al., 2017; Cui et al., 2019).

High oceanic silica concentration in the Ediacaran has been further implicated as a cause of chert precipitation and enhancement of fossil preservation by syngenetic and diagenetic mineralization of organic remains particularly in reducing microenvironments, such as that reconstructed for the Doushantuo Formation of South China (Muscente et al., 2015; Shang et al., 2018) and Ediacara Member of South Australia, where pervasive silica precipitation cemented casts and molds of softbodied organisms (Tarhan et al., 2016). We suggest that not only the preservation mode has been prompted by high silica concentration, but that metazoans invented the biochemical sequestration of silica into their walls for constructing the skeleton due to this condition, and much earlier as recorded in the Digermulen Penisula.

The cold-water ocean with high silica concentration flooded the margin of Baltica during the post-Gaskiers deglaciation, and such marine conditions are in concert with the position of Baltica in the high paleolatitudes $\left(30-60^{\circ} \mathrm{S}\right.$; Torsvik and Cocks, 2017). Globally, the cold-water masses that are prone to silica saturation extend in high-latitude oceans (deep and shallow layers) and in the deep bottom layers in equatorial to low latitudes. Oceans have been stratified with respect to the thermal gradient throughout most of geologic history, and the surface temperature either follows climatic zones (Leeder, 1994; Garrison, 1999) or is uniformly low during the glacial periods, as in the Cryogenian (Hoffman and Schrag, 2002; Hoffman et al., 2017). The middle Ediacaran environmental conditions and marine silica saturation in the basin of the Digermulen Peninsula could have imposed and been opportunistically utilized by macroscopic animals, which needed support for their soft bodies by constructing skeletons.

The primary siliceous skeletons of the new taxa appear to be in contrast to exclusively calcareous skeletons of the terminal Ediacaran animals (Namacalathus, Namapoikia), given that calcite/aragonite are currently thought to be the only minerals precipitated by early biomineralizing organisms (Wood et al., 2019; but see Yang et al., 2020). The paleogeographic position of successions bearing these calcareous skeletal animals is in, or restricted to, the intermediate to equatorial paleolatitudes (Zhuravlev et al., 2012; Warren et al., 2017), thus both climate and marine water were warm. Widespread marine cements facilitated the calcareous mineralogy of animal skeletons and were suitable for development of reefal and biohermal ecosystems at this time (Wood et al., 2019). The environmental conditions, ocean water chemistry, and $\mathrm{Ca}$ ion concentration have been inferred to trigger skeletonization in these animals (Grotzinger et al., 2000; Wood, 2011; Penny et al., 2017; Wood et al., 2017, 2019). However, diametrically different conditions existed when (25 Ma earlier) and where (high paleolatitudes, cold climate, and 
deglaciation zone) the new taxa appeared, and their ecology and metabolism have to be assessed accordingly.

\section{Paleoecological implications}

Deduced from the depositional setting of the Stáhpogieddi Formation (Reading and Walker, 1966; Banks, 1973; Farmer et al., 1992; Rice et al., 2011; Torsvik and Cocks, 2017) and preservation of fossils, the newly described organisms inhabited the marine offshore shelf of a marginal inland basin located in high southern paleolatitudes, in quiet and below wave-base conditions during the transgressive, cold-water flooding in the post-glacial time (Reading and Walker, 1966; Banks, 1973; Farmer et al., 1992; Rice et al., 2011; Torsvik and Cocks, 2017). These environments of non-agitated and light-penetrated clear, welloxygenated water column above the siliciclastic, laminated muddy bottom hosted the sea floor-dwelling, sessile organisms, such as co-occurring Palaeopascichnus and slightly later appearing Aspidella are interpreted to have been (Gehling et al., 2000; Gehling and Droser, 2009; Wan et al., 2014; Burzynski and Narbonne, 2015; Tarhan et al., 2015; Jensen et al., 2018; Kolesnikov et al., 2018). The fossils of the new genera Anulitubus, Coniculus, and Fistula were preserved in situ, although not in a life position (post-mortem collapse) and without transport (autochthonous assemblage) because there is no record of sedimentary structures indicative of currents, wave activity, water flow, or dragging. The lifestyle of these organisms, based on functional morphology of their skeletons with closed proximal and opened apertural ends, distinct longitudinal polarity, but without ventral-dorsal orientation, was most likely that of a benthic, sessile organism.

The skeleton aperture functioned likely as oral opening, which was probably lined with tentacle-like organs or chaetae to actively collect or passively uptake nutrient particles during suspension or filter feeding. From the initial skeleton with probable attachment structures (cup- and knob-shaped elements) or simple proximal cone point that was formed in the nepionic larval stage and embedded in the sediment, the organism grew above the substrate and added to the skeleton upward around the apertural opening. Such reconstructions imply an upright epibenthic life position. Forming skeletons to support their sizable soft bodies in an upright position might be beneficial for the uptake of nutrients from the water column and still being firmly settled at the sea floor. These organisms were probably feeding on bacteria and unicellular algae that formed microplankton ("marine snow") and not on the ground bacterial mats (neither recognized by the presence of organic films nor the sediment texture).

As for Anulitubus n. gen., the life history may be further suggested. This organism larva formed the cup element and the tube was secreted into adult stage and achieved the full diameter after the first annular segment either was ready or increased minimally. The tube compartments, equivalent to the annular segment spaces, were separated by incomplete septa and the organism occupied the last, distal compartment at the time while constructing the wall of the next segment, and having a widely open aperture to the environment outside. The central hole in incomplete septum provided the free connection between compartments and possibly the way for attachment to the tube bottom by a sort of organic thread or peduncle-like extension to keep the organism permanently within the tube and not risking it being expelled through the aperture and lost.

Specimens of Anulitubus n. gen., Coniculus n. gen., and Fistula $\mathrm{n}$. gen. were all found in close proximity as solitary individuals, but in contrast to other Ediacaran organisms that were living in more abundant and inter-related communities (Cai et al., 2014; Wood et al., 2019), they do not appear to have been communal. For example, Cloudina, Conotubus, and Sinotubulites have been recognized as sessile, gregarious organisms living on the bottom floor covered by microbial mats and in association with thrombolitic and stromatolitic reefs or bioherms on carbonate platform ramp (Germs, 1972; Grant, 1990; Cai et al., 2014, 2015). Shaanxilithes and Gaojiashania are also thought to be epibenthic organisms (Cai et al., 2010, 2013; Tarhan et al., 2014).

The late Ediacaran ecosystems (ca. 570-540 Ma) of softbodied and biomineralizing animals alongside the Ediacara-type organisms have been reconstructed as diverse and highly integrated communities in the shoreface sandy shelf, restricted lagoonal to inner and outer ramp of carbonate platform settings, with a sea floor rich in microbial mats (Wood et al., 2019). These various settings were paleogeographically located in the intermediate to low latitudes (Zhuravlev et al., 2012; Torsvik and Cocks, 2017; Warren et al., 2017) and in warm climate zones with intense carbonate precipitation in warm-water environments.

The early, ca. 571 Ma ecosystem reconstructed from Avalonia, Newfoundland, is dominated by rangeomorphs and consists of taxonomically rich, leaf-like, frondose morphotypes with holdfasts, that were benthic and oriented upright in the water column (Liu et al., 2015; see Pu et al., 2016 for age; Butterfield, 2020). This biota lived in deep-water marine, aphotic environments at the time and later on (ca. 560-555 Ma) in other shallower-water environments (Narbonne et al., 2014; Liu et al., 2015; Wood et al., 2019). The Avalonian deep basinal setting recorded by siliciclastic hemipelagites (mud, silt) that developed in the turbiditic facies was located in high paleolatitudes (40-60 ${ }^{\circ}$ S; Liu et al., 2015). Similarly, the diverse frondose and modular rangeomorphs, arboreomorphs, and erniettomorphs thrived on the sea floor, in aphotic zone of the deepwater setting in the Mackenzie Mountains of Laurentia, at ca. 580-560 Ma interval (Narbonne et al., 2014). This basin was equatorially positioned at the time (Torsvik and Cocks, 2017). The deep marine environment in the aphotic zone has been inferred to be the site of the origin of the rangeomorph biota and, accordingly, their osmotic mode of feeding (Narbonne et al., 2014; Liu et al., 2015). Recently, rangeomorphs have been revised as being not osmotrophic, but rather heterotrophic and digesting substrates, likely living in symbiosis with a resident microbiome, and within the total-group Eumetazoa (Butterfield, 2020). Although the Laurentian and Avalonian basins were widely paleogeographically spread across equatorial to high paleolatitudes, they both represent deep-basinal and thus cold-water environments. Subsequently, the same taxa existed in shallow marine environments ca. $560 \mathrm{Ma}$ (Wood et al., 2019), which were warm water and in the photic zone. The puzzle remains how the rangeomorphs and similar biota adapted without change in morphology and physiology from their initial deep, cold-water, aphotic environments to shallow, warm-water, and photic environments? 
To these reconstructions, the ecosystem estimated to ca. $575 \mathrm{Ma}$ from the shallower marine, offshore shelf but cold-water setting on the Digermulen Peninsula has to be added. This ecosystem comprised epibenthic macroscopic organisms and neritic microplankton. Epibenthic were the new genera Anulitubus, Coniculus, and Fistula animals, Palaeopascichnus (Gehling and Droser, 2009; Wan et al., 2014), which is a protistan foraminiferan (Antcliffe et al., 2011; Kolesnikov et al., 2018), and slightly above appearing Aspidella, which is a member of the Ediacara biota of unknown affinity (Gehling et al., 2000; Burzynski and Narbonne, 2015). The planktonic photosynthesizing microorganisms were organic-walled acritarchs that are predominantly of algal affinities (Moczydłowska, 2016; Liu and Moczydłowska, 2019) and filamentous cyanobacteria (unpublished data). Benthic bacterial mats are not yet recorded, but this may reflect a taphonomic bias because of the sediment oxidation, and they are more susceptible to decay in comparison with resistant cysts of acritarchs.

The Digermulen ecosystem extended in the high paleolatitude $\left(30-60^{\circ} \mathrm{S}\right)$, cold-water marine shelf with siliciclastic sedimentation, in the photic zone, and above the oxic chemocline. During the post-Gaskiers deglaciation, the revived hydrological cycle that caused mixing of the well-oxygenated water and increased input of mineral nutrients into the marine basin from weathering of the uncovered Baltica paleocontinent created habitats for oxygen-demanding animals and favorable living conditions. The autotrophic photosynthesizers forming the marine snow and living on the sea floor generated the organic matter for the consumers. This ecosystem hosted the earliest silica biomineralizing animals described here.

We suggest that the cold-water environments, not necessarily restricted by the depth but by the temperature, were the sites of the earliest frondose-like biota expansion. If the rangeomorph biota is epifaunal (Narbonne et al., 2014) and among total-group eumetazoan (Butterfield, 2020), the Avalon assemblage included candidate cnidarians (Liu et al., 2014; Wood et al., 2019) and the animal Dickinsonia (Hoyal Cuthill and Han, 2018; Bobrovskiy et al., 2018), and the new biomineralizing taxa were animals, therefore the records at ca. 575-571 Ma show the radiation of animals. There were both small but macroscopic skeletal animals and large soft-bodied biota occurring in shallow- and deep-marine environments, but all cold-water. The evolution of biomineralization by silica, as recorded in the Digermulen Basin, seems to be confined to cold-water and oxic environments.

The Cold Cradle hypothesis was proposed for the evolution of the Ediacara biota and facilitated by the increased $\mathrm{O}_{2}$ availability in cold water environments (Fedonkin, 2003). More recently, it has been suggested that estimates of $\mathrm{O}_{2}$ level in the ocean would be not sufficient to develop diverse ecosystems and, instead, thermal stability, not necessarily cold conditions, has been hypothesized for the deep-water origin of Ediacara biota (Boag et al., 2018). We suggest the stenothermal (Boag et al., 2018) but coldwater (Fedonkin, 2003; the Digermulen Basin herein) environments for the origin of the frondose Ediacara biota (deep water but expansion into shallow water) and for the earliest biomineralization (shallow, cold-water environments).

\section{Conclusions}

The three newly described monotypic genera Anulitubus, Coniculus, and Fistula of macroscopic body fossils with mineralized walls display morphologic features, radial symmetry, and longitudinal polarity that are consistent with being skeletons of animals. Their paleoecology and the paleoenvironment of a marine shelf with well-oxygenated, cold quiet water in the photic zone above the muddy sea-floor support this interpretation and, together with characteristic functional morphology of the exoskeletons, suggest epibenthic mode of life and suspension/filter feeding by these animals. The new species differ from any previously described Ediacaran body fossils by spacial arrangement of annuli and segments, and by being uniquely primarily silicified.

The single- and double-layered skeletons are siliceous and their composition and primary mineralogy are revealed by petrography and various geochemical analyses, and supported by diagenetic processes of the host sediment. Biomineralization by silica was likely facilitated by the environmental conditions of cold, marine waters with high silica concentration, which are typical of silica sequestration into organismal skeletons. Such environments of a cold-water marine shelf existed in the Digermulen Basin during the post-Gaskiers (>580 Ma) deglaciation time and contemporaneously with the appearance of the new taxa. These environments could have forced and been opportunistically utilized by the increase in size of the animals, which needed support for their soft bodies by constructing skeletons. The new species evolved biochemical sequestration of silica into their walls and preceded significantly calcareous biomineralizing sponge (Namapoikia) and putative lophophorate animals (Namacalathus) at the 550 Ma terminal Ediacaran.

The age of the new fossil taxa is broadly bracketed within 580-541 Ma, but shortly post-dating the $580 \mathrm{Ma}$ underlying Mortensneset Diamictite, which is coeval with the Gaskiers Glaciation. This age is estimated at ca. $575 \mathrm{Ma}$ by the age interpolation within the sedimentologically continuous succession bracketed within 580-541 Ma and further constrained by the 558-555 Ma chronostratigraphic ages of the overlying Ediacaran biota.

The reported fossils are the earliest known in the evolutionary history biomineralizing animals that secreted siliceous skeletons and the only ones known from the Ediacaran Period. The phylogenetic affinity of the new genera remains un-resolved, but the body plan, complexity of skeleton with annulate elements, and initial larval structures indicate eumetazoan grade of organismal organization. The new biomineralizing animals evince the radiation among other Ediacaran organisms that are recorded by soft-bodied rangeomorphs of unknown affinities and appearing at $571 \mathrm{Ma}$. The oldest putative animals, including cnidarians and bilaterians preserved as carbonaceous compressions, the Lantian biota, are estimated here to ca. 620-580 Ma in age. The divergence of diverse Ediacaran animals that were soft-bodied and subsequently biomineralizing by silica and calcareous minerals is recorded by fossils in the evolutionary stepwise pattern since ca. $620 \mathrm{Ma}$ until the beginning of the Cambrian. 


\section{Acknowledgments}

This work was funded by the Swedish Research Council (Vetenskåpsrådet) project grant $\mathrm{Nr}$ 621-2012-1669 to M. Moczydłowska. Analytical work by J. Majka was partly supported by AGH-UST grant no. 16.16.140.315. We thank $\varnothing$. Hammer (University of Oslo) for his guidance in tomographic analyses and the Natural History Museum, University of Oslo, for access to the Computed Tomography facilities. We thank J. O. Ebbestad (Uppsala University, Museum of Evolution) for reviewing the taxonomic descriptions of the early draft, additional tomographic analyses of Coniculus n. gen., photographing some specimens in RLM, and discussions on the early skeletal metazoans. We are also grateful to J. Schiffbauer and an anonymous reviewer, and the editors J. Jin and A. Liu for their helpful comments on this manuscript.

\section{Author contributions}

M.M. collected the fossils, conceived the study, conducted microscopic (RLM, STEM) and geochemical (chemical tests, STEM EDS) studies, and analyzed the data. M.M. and B.P.K. wrote the paper with contributions from co-authors. D.S. and B.P.K. compiled the tomographic data. L.L. and P.L. conducted the spectroscopy analyses. J.M. conducted EMP EDS analysis on thin sections and petrographic thin sections examination. All authors participated in discussions on the results.

\section{Competing interests}

The authors declare no competing interests.

\section{Accessibility of supplementary data}

Data available from the Dryad Digital Repository: https://doi. org/10.5061/dryad.08kprr51f.

\section{Publisher's note}

Publisher remains neutral with regard to jurisdictional claims in published maps and institutional affiliations.

\section{References}

Adl, S.M., Simpson, A.G.B., Lane, C.E., et al., 2012, The revised classification of eukaryotes: The Journal of Eukaryotic Microbiology, v. 59, p. 429-493.

Adl, S.M., Bass, D., Lane, C.E., et al., 2019, Revisions to the classification, nomenclature, and diversity of eukaryotes: Journal of Eukaryotic Microbiology, v. 66, p. 4-119.

Antcliffe, J.B., Gooday, A.J., and Brasier, M.D., 2011, Testing the protozoan hypothesis for Ediacaran fossils: a developmental analysis of Palaeopascichnus: Palaeontology, v. 54, p. 1157-1175.

Banks, N., 1973, Innerelv Member: late Precambrian marine shelf deposits, east Finnmark: Norges Geologiske Unders $ø$ kelse, v. 288, p. 7-25.

Banks, N., Edwards, M.B., Geddes, W.P., Hobday, D.K., and Reading, H.G., 1971, Late Precambrian and Cambro-Ordovician sedimentation in east Finnmark: Norges Geologiske Unders $ø$ kelse, v. 269, p. 197-244.

Bechstädt, T., Jäger, H., Rittersbacher, A., Schweisfurth, B., Spence, G., Werner, G., and Boni, M., 2018, The Cryogenian Ghaub Formation of Namibianew insights into Neoproterozoic glaciations: Earth-Science Reviews, v. 177 , p. $678-714$.

Bengtson, S., 2004, Early skeletal fossils, in Lipps, J.H., and Wagooner, B.M., eds., Neoproterozoic-Cambrian Biological Revolutions: The Paleontological Society Papers, v. 10, p. 67-77.

Billings, E., 1872, On some fossils from the primordial rocks of Newfoundland: Canadian Naturalist and Quarterly Journal of Science, v. 6, p. 465-479.
Blair, J.E., 2009. Animals (Metazoa), in Blair Hedges, S., and Kumar, S., eds., The Timetree of Life: New York, Oxford University Press, p. 223-230.

Boag, T.H., Stockey, R.G., Elder, L.E., Hull, P.M., and Sperling, E.A., 2018, Oxygen, temperature and the deep-marine stenothermal cradle of Ediacaran evolution: Proceedings of the Royal Society B, v. 285, p. 1-10.

Bobrovskiy, I., Hope, J.M., Ivantsov, A., Nettersheim, B.J., Hallmann, C., and Brocks, J.J., 2018, Ancient steroids establish the Ediacaran fossil Dickinsonia as one of the earliest animals: Nature, v. 361, p. 1246-1249.

Bobrovskiy, I., Krasnova, A., Ivantsov, A., Luzhnaya (Serezhnikova) E., and Brocks, J.J., 2019, Simple sediment rheology explains the Ediacara biota preservation: Nature Ecology \& Evolution, v. 3, p. 582-589. https://doi. org/10.1038/s41559-019-0820-7.

Bowring, S.A., and Schmitz, M.D., 2003, High-precision U-Pb zircon geochronology and the stratigraphic record: Reviews in Mineralogy and Geochemistry, v. 53, p. 305-326.

Bowring, S.A., Grotzinger, J.P., Condon, D.J., Ramezani, J., Newall, M.J., and Allen, P.A., 2007, Geochronologic constraints on the chronostratigraphic framework of the Neoproterozoic Huqf Supergroup, Sultanate of Oman: American Journal of Science, v. 307, p. 1097-1145.

Bowyer, F., Wood, R.A., and Poulton, S.W., 2017, Controls on the evolution of Ediacaran metazoan ecosystems: a redox perspective: Geobiology, v. 15, p. $516-551$.

Brasier, M.D., Cowie, J., and Taylor, M., 1994, Decision on the PrecambrianCambrian boundary stratotype: Episodes, v. 17, p. 3-8.

Burzynski, G., and Narbonne, G.M., 2015, The discs of Avalon: relating discoid fossils to frondose organisms in the Ediacaarn of Newfoundland, Canada: Palaeogeography, Palaeoclimatology, Palaeoecology, v. 434, p. 34-45.

Burzynski, G., Dececchi, T.A., Narbonne, G.M., and Dalrymple, R.W., 2017a, Cryogenian Aspidella from northwestern Canada: Precambrian Research, v. 336, 105507.

Burzynski, G., Narbonne, G.M., Dececchi, T.A., and Dalrymple, R.W., 2017b, The ins and outs of Ediacaran discs: Precambrian Research, v. 300, p. 246260.

Bütschli, O., 1910, Vorlesungen über vergleichende Anatomie. Erster Band, 1. Lieferung: Berlin, Springer, $931 \mathrm{p}$.

Butterfield, N.J., 2020.Constructional and functional anatomy of Ediacaran rangeomorphs: Geological Magazine, https://doi.org/10.1017/ S0016756820000734.

Cai, Y. and Hua, H., 2007, Pyritization in the Gaojiashan Biota: Chinese Sciences Bulletin, v. 52, p. 645-650.

Cai, Y., and Hua, H., 2011, Discussion of "First finds of problematic Ediacaran Fossil Gaojiashania in Siberia and its origin": Geological Magazine, v. 148, p. 329-333.

Cai, Y., Hua, H., Xiao, S., Schiffbauer, J.D., and Li, P., 2010, Biostratinomy of the late Ediacaran pyritized Gaojiashan Lagerstätte from southern Shaanxi, South China: importance of event deposits: Palaios, v. 25, p. 487-506.

Cai, Y., Schiffbauer, J.D., Hua, H., and Xiao, S., 2011, Morphology and paleoecology of the late Ediacaran tubular fossil Conotubus hemmianulatus from the Gaojianshan Lagerstätte of southern Shaanxi Province, South China: Precambrian Research, v. 191, p. 46-57.

Cai, Y., Schiffbauer, J.D., Hua, H., and Xiao, S., 2012, Preservational modes in the Ediacaran Gaojiashan Lagerstätte: Pyritization, aluminosilication, and carbonaceous compression: Palaeogeography, Plalaeoclimatology, Palaeoecology, v. 326-328, p. 109-117.

Cai, Y., Hua, H., and Zhang, X., 2013, Tube construction and life mode of the late Ediacaran tubular fossil Gaojiashania cyclus from the Gaojiashan Lagerstätte: Precambrian Research, v. 224, p. 255-267.

Cai, Y., Hua, H., Schiffbauer, J.D., Sun, B., and Yuan, X., 2014, Tube growth patterns and microbial mat-related lifestyle in the Ediacaran fossil Cloudina, Gaojiashan Lagerstätte, South China: Gondwana Research, v. 25, p. 10081018.

Cai, Y., Xiao, S., Hua, H., and Yuan, X., 2015, New material of the biomineralizing fossil Sinotubulites from the late Ediacaran Dengying Formation, South China: Precambrian Research, v. 261, p. 12-24.

Cai, Y., Cortijo, I., Schiffbauer, J.D., and Hua, H., 2017, Taxonomy of the late Ediacaran index fossil Cloudina and a new similar taxon from South China: Precambrian Research, v. 298, p. 146-156.

Cai, Y., Xiao, S., Li, G., and Hua, H., 2019, Diverse biomineralizing animals in the terminal Ediacaran Period herald the Cambrian explosion: Geology, v. 47 , p. $380-384$.

Chen, M., Chen, Y., and Qian, Y., 1981, Some tubular fossils from SinianLower Cambrian boundary sequence, Yangtze Gorge: Bulletin of Tianjin Institute of Geology and Mineral Resources, v. 3, p. 117-124 [in Chinese with English abstract]

Chen, Z., Sun, W-G., and Hua, H., 2002, Preservation and morphologic interpretation of late Sinian Gaojiashania from Southern Shaanxi: Acta Palaeontologica Sinica, v. 41, p. 448-454. 
Chen, Z., Bengtson, S., Zhou, C., Hua, H., and Yue, Z., 2008, Tube structure and original composition of Sinotubulites shelly fossils from the late Neoproterozoic in southern Shaanxi, China: Lethaia, v. 41, p. 37-45.

Chen, Z., Zhou, C., Xiao, S., Wang, W., Guan, C., Hua, H., and Yuan, X., 2014, New Ediacara fossils preserved in marine limestone and their ecological implications: Scientific Reports, v. 4:4180, p. 1-10.

Condon, D., Zhu, M., Bowring, S., Wang, W., Yang, A., and Jin, Y., 2005, U-Pb ages from the Neoproterozoic Doushantuo Formation, China: Science, v. 308, p. 95-98.

Cortijo, I., Martí Mus, M., Jensen, S., and Palacios, T., 2010, A new species of Cloudina from the terminal Ediacaran of Spain: Precambrian Research, v. 176 , p. $1-10$.

Cortijo, I., Cai, Y., Hua, H., Schiffbauer, J.D., and Xiao, S., 2015, Life history and autecology of an Ediacaran index fossil: development and dispersal of Cloudina: Gondwana Research, v. 28, p. 419-424.

Cui, H., Grazhdankin, D.V., Xiao, S., Peek, S., Rogov, V.I., Bykova, N.V., Sievers, N.E., Liu, X-M., and Kaufman, A.J., 2016, Redox-dependent distribution of early macro-organisms: evidence from the terminal Ediacaran Khatyspyt Formation in Arctic Siberia: Palaeogeography, Palaeoclimatology, Palaeoecology, v. 461, p. 122-139.

Cui, H., Xiao, S., Cai, Y., Peek, S., Plummer, R.E., and Kaufman, A.J., 2019, Sedimentology and chemostratigraphy of the terminal Ediacaran Dengying Formation at the Gaojiashan section, South China: Geological Magazine, v. 156 , p. 1924-1948. https://doi.org/10.1017/S0016756819000293.

Cunningham, J.A., Vargas, K., Yin, Z., Bengtson, S., and Donoghue, P.C.J., 2017, The Weng'an Biota (Doushantuo Formation): an Ediacaran window on soft-bodied and multicellular microorganisms: Journal of Geological Society, v. 174, p. 793-802. https://doi.org/10.1144/jgs2016-142.

Dallmeyer, R.D., Reuter, A., Clauer, N., and Liewig, N., 1989, Chronology of Caledonian tectonothermal activity within the Gaissa and Laksefjord Nappe Complex (Lower Allochthon), Finnmark, Norway: evidence from K-Ar and ${ }^{40} \mathrm{Ar} /{ }^{39} \mathrm{Ar}$ ages, in Gayer, R.A., ed., The Caledonide Geology of Scandinavia: London, Graham \& Trotman, p. 9-26.

Dalrymple, R.W., Ichaso, A.A., and Narbonne, G.M., 2006: Paleoenvironmental and basin analysis of the late Neoproterozoic (Ediacaran) upper Conception and St. John's groups, west Conception Bay, Newfoundland: Canadian Journal of Earth Sciences, v. 44, p. 25-41.

Davies, N.S., Shillito, A.P., and McMahon, W.J., 2019, Where does the time go? Assessing the chronostratigraphic fidelity of sedimentary geologica outcrops in the Pliocene-Pleistocene Red Crag Formation, eastern England: Journal of the Geological Society, v. 176, 1154-1168.

Dong, L., Shen, B., Lee, C., Shu, X., Peng, Y., Sun, Y., Tang, Z., Rong, H., Lang, X., Ma, H., Yang, F., and Guo, W., 2015, Germanium/silicon of the Ediacaran-Cambrian Laobao cherts: implications for the bedded chert formation and paleoenvironment interpretation: Geochemistry, Geophysics, Geosystems, v. 16, p. 751-763.

dos Reis, M., Thawornwattana, Y., Angelis, K., Telford, M.J., Donoghue, P.C.J., and Yang, Z., 2015, Uncertainty in the timing of origin of animals and the limits of precision in molecular timescales: Current Biology, v. 25, p. 2939 2950 .

Edwards, M.B., 1984, Sedimentology of the Upper Proterozoic glacial record, Vestertana Group, Finnmark, north Norway: Norges Geologiske Undersøkelse Bulletin, v. 394, p. 1-76.

Erwin, D.H., and Valentine, J.W., 2013, The Cambrian Explosion: The Construction of Animal Biodiversity: Greenwood Village, Colorado, Roberts and Company, p. 1-406.

Erwin, D.H., Laflamme, M., Tweedt, S.M., Sperling, E.A., Pisani, D., and Peterson, K.J., 2011, The Cambrian conundrum: early divergence and late ecological success in the early history of animals: Science, v. 334, p. 10911097.

Farmer, J., Vidal, G., Moczydłowska, M., Strauss, H., Ahlberg, P., and Siedlecka, A., 1992, Ediacaran fossils from the Innerelv Member (late Proterozoic) of the Tanafjorden area, northeast Finnmark: Geological Magazine, v. 129, p. 181-195.

Fedonkin, M.A., 1982, A new generic name for a Precambrian coelenterate: Paleontologicheskiy Zhurnal, v. 2, p. 137. [in Russian]

Fedonkin, M.A., 2003, The origin of the Metazoa in the light of the Proterozoic fossil record: Paleontological Research, v. 7, p. 9-41.

Fedonkin, M.A., and Vickers-Rich, P., 2007, The White Sea's windswept coasts, in Fedonkin, M.A., Gehling, J.G., Grey, K., Narbonne, G.M., and Vickers-Rich, P., eds., The Rise of Animals. Evolution and Diversification of the Kingdom Animalia: Baltimore, The Johns Hopkins University Press, p. $115-147$.

Fedonkin, M.A., Simonetta, A., and Ivantsov, A.Y., 2007a, New data on Kimberella, the Vendian mollusc-like organism (White Sea region, Russia): palaecological and evolutionary implications, in Vickers-Rich, P., and Komarower, P., eds.,: The Rise and Fall of the Ediacaran Biota: Geological Society, London, Special Publication, v. 286, p. 157-179.
Fedonkin, M.A., Gehling, J.G., Grey, K., Narbonne, G.M., and Vickers-Rich, P., eds., 2007b, The Rise of Animals. Evolution and Diversification of the Kingdom Animalia: Baltimore, The Johns Hopkins University Press, p. $1-326$.

Føyn, S., 1985, The Late Precambrian in northern Scandinavia, in Gee, D.G., and Sturt, B.A., eds., The Caledonide Orogen-Scandinavia and Related Areas. Part 1: Chichester, John Wiley \& Sons, p. 233-245.

Garrison, T., 1999, Oceanography: An Invitation to Marine Science. Third Edition: Belmont, Wadsworth Publishing Company, p.1-552.

Gayer, R.A., and Rice, A.H.N., 1989, Palaeogeographic reconstruction of the pre- to syn-Iapetus rifting sediments in the Caledonides of Finnmark, in Gayer, R.A., ed., The Caledonide Geology of Scandinavia: London, Graham \& Trotman, p. 127-139.

Gayer, R.A., Rice, A.H.N., Roberts, D., Townsend, C., and Welbon, A.I.F., 1987, Restoration of the Caledonian Baltoscandian margin from balanced cross-sections: the problem of excess continental crust: Transactions of the Royal Society of Edinburgh: Earth Sciences, v. 78, p. 197-217.

Gee, D.G., and Sturt, B., eds., 1985, The Caledonide Orogen-Scandinavia and Related Areas: Chichester, John Wiley \& Sons, p. 1-1266.

Germs, G.J.B., 1972, New shelly fossils from the Nama Group, South Africa American Journal of Science, v. 272, p. 752-761.

Gehling, J.G., and Droser, M.L., 2009, Textured organic surfaces associated with the Ediacaran biota in South Australia: Earth-Science Reviews, v. 96, p. 196-206.

Gehling, J.G., Narbonne, G.M., and Anderson, M.M., 2000, The first named Ediacaran body fossil: Aspidella terranovica: Palaeontology, v. 43, p. $427-456$.

Gibson, B.M., Rahman, I.A., Maloney, K.M., Racicot, R.A., Mocke, H., Laflamme, M., and Darroch, S.A.F., 2019, Gregarious suspension feeding in a modular Ediacaran organism: Science Advances, v. 5:eaaw0260, p. 19. https://doi.org/10.1126/sciadv.aaw0260.

Grant, S.W.F., 1990, Shell structure and distribution of Cloudina, a potential index fossil for the terminal Proterozoic: American Journal of Science, v. 290-A, p. 261-294.

Grazhdankin, D.V., 2014, Patterns of evolution of the Ediacaran soft-bodied biota: Journal of Paleontology, v. 88, p. 269-283.

Grazhdankin, D.V., and Maslov, A.V., 2009, Sequence stratigraphy of the upper Vendian of the East European Craton: Doklady Earth Sciences, v. 426, p. $517-521$.

Grazhdankin, D.V., and Maslov, A.V., 2015, The room for the Vendian in the International Chronostratigraphic Chart: Russian Geology and Geophysics, v. 56, p. 549-559.

Grey, K., 2005, Ediacaran palynology of Australia: Memoir of the Association of Australasian Palaeontologists, v. 31, p. 1-439.

Grotzinger, J.P., Bowring, S.A., Saylor, B.Z., and Kaufman, A.J., 1995, Biostratigraphic and geochronologic constraints on early animal evolution: Science, v. 270, p. 598-604.

Grotzinger, J.P., Watters, W.A., and Knoll, A.H., 2000, Calcified metazoans in thrombolite stromatolite reefs of the terminal Proterozoic Nama Group, Namibia: Paleobiology, v. 26, p. 334-359.

Haeckel, E., 1874, The gastrea-theory, the phylogenetic classification of the animal kingdom, and the homology of the germ-lamellae: Quarterly Review of Microscopic Sciences, n. ser., v. 14, p. 142-165, 223-247.

Hagadorn, J.W., and Waggoner, B., 2000, Ediacaran fossils from the southwestern Great Basin, United States: Journal of Paleontology, v. 74, p. 349-359.

Hahn, G., Hahn, R., Leonardos, O., Pflug, H.D., and Walde, D., 1982, Körperlich erhaltene Scyphozoen-Reste aus dem Jungpräkambrium Brasiliens: Geologica et Palaeontologica, v. 16, p. 1-18.

Haines, P.W., 2000, Problematic fossils in the late Neoproterozoic Wonoka Formation, South Australia: Precambrian Research, v. 100, p. 97-108.

Halverson, G.P., and Shields-Zhou, G., 2011, Chemostratigraphy and the Neoproterzoic glaciations, in Arnaud, E., Halverson, G.P., and Shields-Zhou, G, eds., The Geological Record of Neoproterozoic Glaciations: Geological Society, London, Memoirs, v. 36, p. 51-66.

Halverson, G.P., Hoffman, P.F., Schrag, D.P., Maloof, A.C., and Rice, A.H., 2005, Towards a Neoproterozoic composite carbon-isotope record: Geological Society of America Bulletin, v. 117, p. 1181-1207.

Halverson, G.P., Wade, B.P., Hurtgen, M.T., and Barovich, K.M., 2010, Neoproterozoic chemostratigraphy: Precambrian Research, v. 182, p. 337-350.

Hoffman, P.F., and Schrag, D.P., 2002, The Snowball Earth Hypothesis: testing the limits of global change: Terra Nova, v. 14, p. 129-155. https://doi.org/ 10.1046/j.1365-3121.2002.00408.x.

Hofmann, H.J., Narbonne, G.M., and Aitken, J.D., 1990, Ediacaran remains from intertillite beds in northwestern Canada: Geology, v. 18, p. 1199-1202.

Hofmann, H.J., O'Brien, S.J., and King, A.F., 2008, Ediacaran biota on Bonavista Pennsula, Newfoundland, Canada: Journal of Paleontology, v. 82, p. $1-36$. 
Hoffman, P.F., Abbot, D.S., Askenazy, Y., et al., 2017, Snowball Earth climate dynamics and Cryogenian geology-geobiology: Science Advances, v. 3: e1600983, p. 1-43.

Högström, A.E.S., Jensen, S., Palacios, T., and Ebbestad, J.O.R., 2013, New information on the Ediacaran-Cambrian transition in the Vestertana Group, Finnmark, northern Norway, from trace fossils and organic-walled microfossils: Norwegian Journal of Geology, v. 93, p. 95-106.

Högström, A.E.S., Jensen, S., Ebbestad, J.O.R., Taylor, W.L., Høyberget, M., Agić, H., Meinhold, G., and Palacios, T., 2017, Expanding the Ediacaran biota on the Digermulen Peninsula, Arctic Norway: Abstract Volume to ISECT2017-International Symposium on the Ediacaran-Cambrian transition, St. John's, Memorial University, Geological Survey Newfoundland and Labrador, p. 46.

Holbrook, J.M., and Miall, A.D., 2020, Time in the rock: a guide to interpreting past events and processes from siliciclastic stratigraphy: Earth-Science Reviews, v. 203, 103121, 1-24.

Hoyal Cuthill, J.F., and Han, J., 2018, Cambrian petalonomid Stromatoveris phylogenetically links Ediacaran biota to later animals: Palaeontology, v. 61, p. $813-823$.

Høyberget, M., Högström, A.E.S., Ebbestad, J.O.R, and Jensen, S., 2017, Fantastiske fossil-funn in Finnmark: Naturen, v. 141, 94-100.

Hua, H., Chen, Z., and Zhang, L.Y., 2004, Shaanxilithes from lower Taozichong Formation, Guizhou Province and its geological and paleobiological significance: Journal of Stratigraphy, v. 28, p. 265-269. [in Chinese with English abstract]

Hua, H., Chen, Z., Yuan, X., Zhang, L., and Xiao, S., 2005, Skeletogenesis and asexual reproduction in the earliest biomineralizing animal Cloudina: Geology, v.33, p. 277-280.

Hua, H., Chen, Z., and Yuan, X., 2007, The advent of mineralized skeletons in Neoproterozoic Metazoa-new fossils evidence from the Gaojianshan Fauna: Geological Journal, v. 42, p. 263-279.

Ichaso, A.A., Dalrymple, R.W., and Narbonne, G.M., 2007, Paleoenvironmental and basin analysis of the late Neoproterozoic (Ediacaran) upper Conception and St. John's groups, west Conception Bay, Newfoundland: Canadian Journal of Earth Sciences, v. 44, p. 25-41.

Jensen, S., 1997, Trace fossils from the Lower Cambrian Mixkwitzia Sandstone, south-central Sweden: Fossils \& Strata, v. 42, p. 1-111.

Jensen, S., Högström, A.E.S., Høyberget, M., Meinhold, G., McIlroy, D., Ebbestad, J.O.R., Taylor, W.L., Agic, H., and Palacios, T., 2018, New occurrences of Palaeopascichnus from the Stáhpogieddi Formation, Arctic Norway, and their bearing on the age of the Varanger Ice Age: Canadian Journal of Earth Sciences, v. 55, p. 1253-1261.

Kolesnikov, A.V., Rogov, V.I., Bykova, N.V., Danelian, T., Clausen, S., Maslov, A.V., and Grazhdankin, D.V., 2018, The oldest skeletal macroscopic organism Palaeopascichnus linearis: Precambrian Research, v. 316 , p. $24-37$

Konhauser, K.O., Lalonde, S.V., Amskold, L., and Holland, H.D., 2007, Was there really an Archean phosphate crisis? Science, v. 315, p. 1234.

Kudryavtsev, A.B., Schopf, J.W., Agresti, D.G., and Wdowiak, T.J., 2001, In situ laser-Raman imagery of Precambrian microscopic fossils: Proceedings of the National Academy of Sciences of the United States of America, v. 98, p. 823-826.

Landing, E., 1994, Precambrian-Cambrian boundary global stratotype ratified and a new perspective of Cambrian time: Geology, v. 22, p. 179-182.

Leeder, M.R., 1994, Sedimentology Process and Product: London, Chapman \& Hall, p. 1-344.

Lin, S., Zhang, Y., and Zhang, L., 1986, Body and trace fossils of metazoan and algal macrofossils from the Upper Sinian Gaojiashan Formation in southern Shaanxi: Geology of Shaanxi, v. 4, p. 9-19.

Linnemann, U., Ovtcharova, M., Schaltegger, U., Gärtner, A., Hautmann, M., Geyer, G., Vickers-Rich, P., Rich, T., Plessen, B., Hofmann, M., Zieger, J., Krause, R., Kriesfeld, L., and Smith, J., 2019, New high-resolution age data from the Ediacaran-Cambrian boundary indicate rapid, ecologically driven onset of the Cambrian explosion: Terra Nova, v. 31, p. 49-58.

Liu, A., Kenchington, C.G., and Mitchell, E.G., 2015, Remarkable insights into the paleoecology of the Avalonian Ediacaran macrobiota: Gondwana Research, v. 27, p. 1355-1380.

Liu, P., Xiao, S., Yin, C., Chen, S., Zhou, C., and Li, M., 2014, Ediacaran acanthomorphic acritarchs and other microfossils from chert nodules of the Upper Doushantuo Formation in the Yangtze Gorges area, South China: The Paleontological Society Memoir, v. 72, p. 1-139.

Liu, P., and Moczydłowska, M., 2019, Ediacaran microfossils from the Doushantuo Formation chert nodules in the Yangtze Gorges area, South China, and new biozones: Fossils and Strata, v. 65, p. 1-172.

Lowenstam, H.A., 1981, Minerals formed by organisms: Science, v. 211, p. $1126-1131$

Lowenstam, H.A., and Weiner, S., 1989, On Biomineralization: New York, Oxford University Press, p. 1-336.
Maliva, R.G., Knoll, A.H., and Simonson, B.M., 2005, Secular change in the Precambrian silica cycle: insights from chert petrology: Geological Society of America, Bulletin, v. 117, p. 835-845.

Martin, M.W., Grazhdankin, D.V., Bowring, S.A., Evens, D.A.D, Fedonkin, M.A., and Kirschvink, J.L., 2000, Age of Neoproterozoic bilaterian body and trace fossils, White Sea, Russia: implications for metazoan evolution: Science, v. 288, p. 841-845.

McIlroy, D., and Brasier, M.D., 2017, Ichnological evidence for the Cambrian explosion in the Ediacaran to Cambrian succession of Tanafjord, Finnmark, northern Norway, in Brasier, A.T., McIlroy, D., and McLoughlin, N., eds., Earth System Evolution and Early Life: A Celebration of the Work of Martin Brasier: Geological Society, London, Special Publications, v. 448, p. 351-368.

Meinhold, G., Wemmer, K., Högström, A.E.S., Ebbestad, JO.R., Jensen, S., Palacios, T., Høyberget, M., Agić, H., and Taylor, W.L., 2019a, A late Caledonian tectono-thermal event in the Gaissa Nappe Complex, Arctic Norway: evidence from fine-fraction $\mathrm{K}-\mathrm{Ar}$ dating and illite crystallinity from the Digermulen Peninsula: GFF, v. 141, p. 289-294. https://doi.org/ 10.1080/11035897.2019.1583685.

Meinhold, G., Jensen, S., Høyberget, M., Arslan, A., Ebbestad, J.O.R., Högström, A.E.S., Palacios, T., Agić, H., and Taylor, W.L., 2019b, First record of carbonates with spherolites and cone-in-cone structures from the Precambrian of Arctic Norway, and their palaeoenvironmental significance: Precambrian Research, v. 328, p. 99-110.

Meyer, M., Schiffbauer, J.D., Xiao, S., Cai, Y., and Hua, H., 2012, Taphonomy of the upper Ediacaran enigmatic ribbonlike fossil Shaanxilithes: Palaios, v. 27 , p. 354-372.

Meyer, M., Elliot, D., Schiffbauer, J.D., Hall, M., Hoffman, K.H., Schneider, G., Vickers-Rich, P., and Xiao, S., 2014, Taphonomy of the Ediacaran fossil Pteridinium simplex preserved three-dimensionally in mass flow deposits, Nama Group, Namibia: Journal of Paleontology, v. 88, p. 240-252.

Miller, S.A., 1889, North American Geology and Palaeontology for the use of amateurs, students, and scientists: Cincinnati, Ohio, Western Methodist Book Concern, $718 \mathrm{p}$.

Moczydłowska, M., 2016, Algal affinities of Ediacaran and Cambrian organicwalled microfossils with internal reproductive bodies: Tanarium and other morphotypes: Palynology, v. 40, p. 83-121. https://doi.org/10.1080/ 01916122.2015.1006341.

Moczydłowska, M., Westall, F., and Foucher, F., 2014, Microstructure and biogeochemistry of the organically preserved Ediacaran metazoan Sabellidites: Journal of Paleontology, v. 88, p. 224-239.

Murdock, D.J.E., 2020, The "biomineralization toolkit" and the origin of animal skeletons: Biological Reviews, v. 95, p. 1372-1392. https://doi.org/10. 1111/brv.12614.

Muscente, A.D., Hawkins, A.D., and Xiao, S., 2015, Fossil preservation through phosphatization and silicification in the Ediacaran Doushantuo Formation (South China): a comparative synthesis: Palaeogeography, Plaeoclimatology, Palaeoecology, v. 434, p. 46-62.

Narbonne, G.M., 2005, The Ediacaran Biota: Neoproterozoic origin of animals and their ecosystems: Annual Review of Earth and Planetary Sciences, v. 33, p. 421-442.

Narbonne, G.M., Myrow, P., Landing, E., and Anderson, M.M., 1987, A candidate for the Precambrian-Cambrian boundary, Fortune Head, Burin Peninsula, southeastern Newfoundland: Canadian Journal of Earth Sciences, v. 24 , p. $277-293$

Narbonne, G.M., Saylor, B.Z., and Grotzinger, J.P., 1997, The youngest Ediacaran fossils from southern Africa: Journal of Paleontology, v. 71, p. 953-967.

Narbonne, G.M., Xiao, S., and Shields, G., 2012, The Ediacaran Period, in Gradstein, F., Ogg, J., Schmitz, M.D., and Ogg, G., eds., The Geological Time Scale 2012, Volume 1: Amsterdam, Elsevier, p. 413-435.

Narbonne, G.M., Laflamme, M., Trusler, P.W., Dalrymple, R.W., and Greentree, C., 2014, Deep-water Ediacaran fossils from northwestern Canada: taphonomy, ecology, and evolution: Journal of Paleontology, v. 88, p. 207-223.

Nystuen, J.P., 1985, Facies and preservation of glaciogenic sequences from the Varanger ice age in Scandinavia and other parts of the North Atlantic region: Palaeogeography, Plaeoclimatology, Palaeoecology, v. 51, p. 209-229.

Olcott Marshall, A., and Marshall, C.P., 2015, Vibrational spectroscopy of fossils: Palaeontology, v. 58, p. 201-211.

Palij, V.M., 1976, Remains of soft-bodied animals and trace fossils from the Upper Precambrian and the Lower Cambrian of Podolia, in Ryabenko, V.A., ed., Palaeontology and Stratigraphy of the Upper Precambrian and Lower Paleozoic of the Southwestern Part of the East-European Platform: Kiev, Naukova Dumks, p. 63-76. [in Russian]

Peng, S., Babcock. L.E., and Cooper, R.A., 2012, The Cambrian Period. Chapter 19, in Gradstein, F.M., Ogg, J.G., Schmitz, M.D., and Ogg, G.M., eds., The Geologic Time Scale 2012, Volume 2: Amsterdam, Elsevier, p. $437-488$. 
Penman, D.E. and Rooney, A.D., 2019, Coupled carbon and silica cycle perturbations during the Marinoan snowball Earth deglaciation: Geology, v. 47 p. $317-320$.

Penny, A.M., Wood, R.A., Curtis, A., Bowyer, F.T., Tostevin, R., and Hoffman, K.H., 2014, Ediacaran metazoan reefs from the Nama Group, Namibia: Science, v. 344, p. 1504-1506.

Penny, A.M., Wood, R.A., Zhuravlev, A.Yu., Curtis, A., Bowyer, F., and Tostevin, R., 2017, Intraspecific variation in an Ediacaran skeletal metazoan: Namacalathus from the Nama Group, Namibia: Geobiology, v. 15, p. 81-93.

Perry, C.C., 2003, Silicification: the process by which organisms capture and mineralize silica: Reviews in Mineralogy and Geochemistry, v. 54, p. 291-327.

Pruss, S.B., Payne, J.L., Westacott, S., 2015, Taphonomic bias of selective silicification revealed by paired petrographic and insoluble residue analysis: Palaios, v. 30, p. 620-626.

Pruss, S.B., Blättler, C.L., Macdonald, F.A., Higgins, J.A., 2018, Calcium isotope evidence that the earliest metazoan biomineralizers formed aragonite shells: Geology, v. 46, p. 763-766.

Pu, J.P., Bowring, S.A., Ramezani, J., Myrow, P., Raub, T.D., and Landing, E., 2016, Dodging snowballs: geochronology of the Gaskiers glaciation and the first appearance of the Ediacara biota: Geology, v. 44, p. 955-958.

Ramseyer, K., Amthor, J.E., Matter, A., Pettke, T., Wille, M., and Falick, A.E., 2013, Primary silica precipitate at the Precambrian/Cambrian boundary in the South Oman Salt Basin, Sultanate of Oman: Marine and Petroleum Geology, v. 39, p. 187-197.

Reading, H.G., 1965, Eocambrian and lower Palaeozoic geology of the Digermul Peninsula, Tanafjord, Finnmark: Norges Geologiske Unders $\varnothing$ kelse, v. 234 , p. $67-191$.

Reading, H.G., and Walker, R.G., 1966, Sedimentation of Eocambrian tillites and associated sediments in Finnmark, northern Norway: Palaeogeography, Palaeoclimatology, Palaeoecology, v. 2, p. 177-212.

Rice, A.H.N., 2014, Restoration of the external Caledonides, Finnmark, North Norway, in Corfu, F., Gasser, D., and Chew, D.M., eds., New Perspectives on the Caledonides of Scandinavia and Related Areas: Geological Society of London, Special Publications, v. 390, p. 271-299.

Rice, A.H.N., Bevins, R.E., Robinson, D., and Roberts, D., 1989, Evolution of low-grade metamorphic zones in the Caledonides of Finnmark, N. Norway, in Gayer, R.A., ed., The Caledonide Geology of Scandinavia: London, Graham \& Trotman, p. 177-191.

Rice, A.H.N., Edwards, M.B., Hansen, T.A., Arnaud, E., and Halverson, G.P., 2011, Glacigenic rocks of the Smalfjord and Mortensnes formations, Vestertana Group, E. Finnmark, Norway, in Arnaud, E., Halverson, G., and Shields-Zhou, G., eds., The Geological Record of Neoproterozoic Glaciations: Geological Society of London, Memoir, v. 36, p. 593-602.

Rice, A.H.N., Edwards, M.B., and Hansen, T.A., 2012, Neoproterozoic glacial and associated facies in the Tanafjord-Varangerfjord Area, Finnmark, North Norway. The Geological Society of America Field Guide, v. 26, p. 1-83.

Roberts, D., 2003, The Scandinavian Caledonides: event chronology, palaeogeographic settings and likely modern analogues: Tectonophysics, v. 365, p. 283-299.

Roberts, D., and Gee, D.G., 1985, An introduction to the structure of the Scandinavian Caledonides, in Gee, D.G., and Sturt, B.A., eds., The Caledonide Orogen Scandinavia and Related Areas: Chichester, Wiley, p. 55-68.

Roberts, D., and Siedlecka, A., 2002, Timanian orogenic deformation along the northeastern margin of Baltica, northwest Russia and northeast Norway, and Avalonian-Cadomian connections: Tectonophysics, v. 352, p. 169-184.

Schiffbauer, J.D., Xiao, S., Cai, Y., Wallace, A.F., Hua, H., Hunter, J., Xu, H., Peng, Y., and Kaufman, A.J., 2014, A unified model for NeoproterozoicPalaeozoic exceptional fossil preservation through pyritization and carbonaceous compression: Nature Communications, v. 5, 5754. https://doi.org/10. 1038/ncomms6754.

Schiffbauer, J.D., Huntley, J.W., O’Neil, G.R., Darroch, S.A.F., Laflamme, M., and Cai, Y., 2016, The latest Ediacaran Wormworld Fauna: setting the ecological stage for the Cambrian Explosion: GSA Today, v. 26, p. 4-11.

Schiffbauer, J.D., Selly, T., Jacquet, S.M., Merz, R.A., Nelson, L.L., Srange, M.A., Cai, Y., and Smith, E., 2020, Discovery of bilaterian-type throughguts in cloudinomorphs from the terminal Ediacaran Period: Nature Communications, v. 11, 205. https://doi.org/10.1038/s41467-019-13882-z.

Schmitz, M.D., 2012, Radiometric ages used in GTS 2012, in Gradstein, F.M., Ogg, J.G., Schmitz, M.D., and Ogg, G.M., eds., The Geologic Time Scale 2012. Volume 2: Amsterdam, Elsevier, p. 1045-1082.

Schopf, J.W., Kudryavtsev, A.B., Agresti, D.G., Wdowiak, T.J., and Czaja, A.D., 2002, Laser-Raman imagery of Earth's earliest fossils: Nature, v. 416, p. 73-76.

Schopf, J.W., Kudryavtsev, A.B., Agresti, D.G., Czaja, A.D., Wdowiak, T.J., 2005, Raman imagery: a new approach to assess the geochemical maturity and biogenicity of permineralized Precambrian fossils: Astrobiology, v. 5, p. 333-371.
Seilacher, A., 1955, Spuren und Fazies im Unterkambrium, in Schindewolf, O.H., and Seilacher, A., eds., Beiträge zur Kenntniss des Kambriums in der Salt Range (Pakistan): Abhandlungen der MathematischNaturwissenschaftlichen Klasse 1955, p. 373-399.

Selly, T., Schiffbauer, J.D., Jacquet, S.M., et al., 2020, A new cloudinid fossil assemblage from the terminal Ediacaran of Nevada, USA: Journal of Systematic Palaeontology, v. 18 , p. 357-379.

Shang, X., Moczydłowska, M., Liu, P., and Liu, L., 2018, Organic composition and diagenetic mineralization of microfossils in the Ediacaran Doushantuo chert nodules by Raman and petrographic analyses: Precambrian Research, v. 314, p. 145-159.

Shen, B., Xiao, S., Dong, L., Zhou, C., and Liu, J., 2007, Problematic macrofossils from Ediacaran successions in the North China and Chaidam blocks: implications for their evolutionary roots and biostratigraphic significance: Journal of Paleontology, v. 81, p. 1396-1411.

Shen, B., Lee, C-T.A., and Xiao, S., 2011, Germanium/silica ratios in diagenetic chert nodules from the Ediacaran Doushantuo Formation, South China: Chemical Geology, v. 280, p. 323-335.

Shore, A., Wood, R., Curtis, A., and Bowyer, F., 2020, Multiple branching and attachment structures in cloudinomorphs, Nama Group, Namibia, Geology, v. 48, p. 877-881. https://doi.org/10.1130/G47447.1.

Siedlecka, A., 1985, Development of the upper Proterozoic sedimentary basins of the Varanger Peninsula, east Finnmark, north Norway: Geological Survey of Finland, Bulletin, v. 331, p. 175-185.

Siedlecka, A., Reading, H.G., Williams, G.D., and Roberts, D., 2006, Berggrunnskart Longfjorden 2236 II. Preliminary bedrock geology map 2236 II, map scale 1:50.000. Norges Geologiske Unders $\varnothing$ kelse, 2236 II.

Siever, R., 1992, The silica cycle in the Precambrian: Geochimica et Cosmochimica Acta, v. 56, p. 3265-3272.

Smith, E.F., Nelson, L.L., Strange, M.A., Eyster, A.E., Rowland, S.M., Schrag, D.P., and Macdonald, F.A., 2016, The end of the Ediacaran: two new exceptionally preserved body fossil assemblages from Mount Dunfee, Nevada, USA: Geology, v. 44, p. 911-914. https://doi.org/10. 1130/G38157.1.

Sokolov, B.S., 1965, The most ancient early Cambrian deposits and sabelliditids, in Sokolov, B.S., ed., All-Union Symposium on Palaeontology of Precambrian and Early Cambrian: Novosibirsk, Academia Nauk SSSR, p. 78-91.

Sokolov, B.S., 1976, Organic world of the Earth on its way to Phanerozoic differentiation: Vestnik Akademii Nauk SSSR, v. 1, p. 126-143. [in Russian]

Sperling, E.A., and Vinther, J., 2010, A placozoan affinity for Dickinsonia and the evolution of late Proterozoic metazoan feeding modes: Evolution and Development, v. 12, p. 201-209.

Sperling, E.A., Robinson, J.M., Pisani, D., and Peterson, K.J., 2010, Where is the glass? Biomarkers, molecular clocks, and microRNAs suggest a 200-Myr missing Precambrian fossil record of siliceous sponge spicules: Geobiology, v. 8, p. 24-36.

Sperling, E.A., Peterson, K.J., and Laflamme, M., 2011, Rangeomorphs, Thectardis (Porifera?) and dissolved organic carbon in the Ediacaran oceans: Geobiology, v. 9, p. 24-33.

Sprigg, R.G., 1947, Early Cambrian(?) jellyfishes from the Flinders Ranges, South Australia: Transactions of the Royal Society of South Australia, v. 71, p. 212-224.

Stow, D.A.V., 1986, Deep clastic seas, in Reading, H.G., ed., Sedimentary Environments and Facies. Second Edition: Oxford, Blackwell Scientific Publications, p. 399-444.

Straub, K.M., Duller, R.A., Foreman, B.Z., and Hajek, E., 2020, Buffered, incomplete, and shredded: the challenges of reading an imperfect stratigraphic record: Journal of Geophysical Research: Earth Surface, v. 125, p. 1-44. https://doi.org/10.1029/2019JF005079.

Tarhan, L.G., Hughes, N.C., Myrow, P.M., Bhargava, O.N., Ahluwalia, A.D., and Kudryavtsev, A.B., 2014, Precambrian-Cambrian boundary interval occurrence and form of the enigmatic tubular body fossil Shaanxilithes ningqiangensis from the Lesser Himalaya of India: Palaeontology, v. 57, p. 283-298.

Tarhan, L.G., Droser, M.L., Gehling, J.G., and Dzaugis, M.P., 2015, Taphonomy and morphology of the Ediacaran form genus Aspidella: Precambrian Research, v. 257, 124-136.

Tarhan, L.G., Hood, A., Droser, M.L., Gehling, J.G., and Briggs, D.E.G., 2016, Exceptional preservation of soft-bodied Ediacara Biota promoted by silica-rich oceans: Geology, v. 44, p. 951-954.

Tipper, J.C., 2016, Measured rates of sedimentation: What exactly are we estimating, and why?: Sedimentary Geology, v. 339, 151-171.

Torsvik, T.H., and Cocks, L.R.M., 2017, Earth History and Palaeogeography: Cambridge, Cambridge University Press, p. 1-311.

Van Iten, H., Marques, A.C., de Moraes Leme, J., Forancelli Pacheco, M.J.A., and Guimaraes Simões, M., 2014, Origin and early diversification of the phylum Cnidaria Verrill: major developments in the analysis of the taxon's Proterozoic-Cambrian history: Palaeontology, v. 57, p. 677-690. 
Veis, A., 2003, Mineralization in organic matrix frameworks: Reviews in Mineralogy and Geochemistry, v. 54, p. 249-289.

Vickers-Rich, P., 2007, The Nama Fauna of southern Africa, in Fedonkin, M.A., Gehling, J.G., Grey, K., Narbonne, G.M., and Vickers-Rich, P., eds., The Rise of Animals. Evolution and Diversification of the Kingdom Animalia: Baltimore, The Johns Hopkins University Press, p. 69-87.

Wacey, D., 2009, Early Life on Earth-A Practical Guide: Aims and Scope: Topics in Geobiology, Book Series, The Netherlands, Springer, p. 1-274. https://doi.org/10.1007/978-1-4020-9389-0.

Wan, B., Xiao, S., Yuan, X., Chen, Z., Pang, K., Tang, Q., Guan, C., and Maisano, J.A., 2014, Orbisiana linearis from the early Ediacaran Lantian Formation of South China and its taphonomic and ecological implications: Precambrian Research, v. 255, p. 266-275.

Wan, B., Yuan, X., Chen, Z., Guan, C., Pang, K., Tang, Q., and Xiao, S., 2016, Systematic description of putative animal fossils from the early Ediacaran Lantian Formation of South China: Palaeontology, v. 59, p. 515-532.

Wang, W., Guan, C., Zhou, C., Peng, Y., Pratt, L.M., Chen, X., Chen, L., Chen, Z., Yuan, X., and Xiao, S., 2017, Integrated carbon, sulfur, and nitrogen isotope chemostratigraphy of the Ediacaran Lantian Formation in South China: spatial gradient, ocean redox oscillation, and fossil distribution: Geobiology, v. 15 , p. $552-571$.

Weber, B., Steiner, M., and Zhu, M.Y., 2007, Precambrian-Cambrian trace fossils from the Yangtze Platform (South China) and the early evolution of bilaterian lifestyles: Palaeogeography, Palaeoclimatology, Palaeoecology, v. 254, p. $328-349$.

Warren, L.V., Quaglio, F., Simões, M.G., Gaucher, C., Riccomini, C., Poiré, D.G, Tavares Freitas, B., Boggiani, P.C., and Sial, A.N., 2017, Cloudina-Corumbella-Namacalathus association from the Itapucumi Group, Paraguay: increasing ecosystem complexity and tiering at the end of the Ediacaran: Precambrian Research, v. 298, p. 79-87.

Woese, C., Kandler, O., and Wheelis, M.L., 1990, Towards a natural system of organisms: proposal for the domains Archaea, Bacteria, and Eukarya: Proceedings of the National Academy of Sciences of the United States of America USA, v. 87, p. 4576-4579.

Wood, R.A., 2011, Paleoecology of the earliest skeletal metazoan communities: Implications for early biomineralization: Earth-Science Reviews, v. 106, p. $184-190$.

Wood, R.A., and Curtis, A., 2015, Extensive metazoan reefs from the Ediacaran Nama Group, Namibia: the rise of benthic suspension feeding: Geobiology, v. 13, p. $112-122$.

Wood, R.A., Grotzinger, J.P., and Dickson, J.A.D., 2002: Proterozoic modular biomineralized metazoan from the Nama Group, Namibia: Science, v. 296, p. 2383-2386.

Wood, R.A., Curtis, A., Penny, A., Zhuravlev, A.Yu., Curtis-Walcott, S., Iipinge S., and Bowyer, F. 2017, Flexible and responsive growth strategy of the Ediacaran skeletal Cloudina from the Nama Group, Namibia: Geology, v. 45 , p. $259-262$

Wood, R.A., Liu, A.G., Bowyer, F., Wilby, P.R., Dunn, F.S., Kenchington, C.G., Hoyal Cuthill, J.F., Michell, E.G., and Penny, A., 2019, Integrated records of environmental change and evolution challenge the Cambrian Explosion: Nature Ecology and Evolution, v. 3, p. 528-538. https://doi.org/10.1038/ s41559-019-0821-6.

Xiang, Y., Ding, Q., Luo, H., He, T., and Wang, Y., 1984, The Sinian-Cambrian boundary of China: Beijing, Geological Publishing House, 262 p.

Xiao, S., and Laflamme, M., 2009, On the eve of animal radiation: phylogeny, ecology and evolution of the Ediacara biota: Trends in Ecology and Evolution, v. 24, p. 31-40.

Xiao, S., Narbonne, G.M., Zhou, C., Laflamme, M., Grazhdankin, D.V., Moczydłowska-Vidal, M., and Cui, H., 2016, Toward an Ediacaran time scale: problems, protocols, and prospects: Episodes, v. 39, p. 540555.

Yang, B., Steiner, M., Schiffbauer, J.D., Selly, T., Wu, X., Zhang., and Liu, P., 2020, Ultrastructure of Ediacaran cloudinids suggests diverse taphonomic histories and affinities with non-biomineralized annelids: Scientific Reports, 10:535. https://doi.org/10.1038/s41598-019-56317-x.

Yanishevsky, M., 1926, On the remains of the tubular worms from the Cambrian blue clays: Ezhegodnik Russkogo Paleontologicheskogo obshchestva, v. 4, p. 99-112. [in Russian]

Yin, Z., Zhu, M., Davidson, E.H., Bottjer, D.J., Zhao, F., and Tafforeau, P., 2015 , Sponge grade body fossil with cellular resolution dating $60 \mathrm{Myr}$ before the Cambrian: Proceedings of the National Academy of Sciences, USA, v. 112, p. E1453-E1460. https://doi.org/10.1073/pnas.1414577112.

Yuan, X., Chen, Z., Xiao, S., Zhou, C., and Hua, H., 2011, An early Ediacaran assemblage of macroscopic and morphologically differentiated eukaryotes: Nature, v. 470, p. 390-393.

Zhang, W., Roberts, D., and Pease, V., 2015. Provenance characteristics and regional implications of Neoproterozoic, Timanian-margin successions and a basal Caledonian nappe in northern Norway: Precambrian Research, v. 268, p. 153-167. https://doi.org/10.1016/j.precamres.2015.07.006.

Zhang, Z., Hua, H., and Zhang, Z., 2015, Problematic Ediacaran fossil Shannxilithes from the Jiucheng Member of Wangjiawan section in Jinning, Yunnan Province: Acta Palaeontologica Sinica, v. 54, p. 12-28.

Zhou, C., Xiao, S., Wang, W., Guan, C., Ouyang, Q., and Chen, Z., 2017, The stratigraphic complexity of the middle Ediacaran carbon isotopic record in the Yangtze Gorges area, South China, and its implications for the age and chemostratigraphic significance of the Shuram excursion: Precambrian Research, v. 288, p. 23-38.

Zhuravlev, A.Yu., Liñán, E., Gámez Vintaned, J.A., Debrenne, F., and Fedorov, A.B., 2012, New finds of skeletal fossils in the terminal Neoproterozoic of the Siberian Platform and Spain: Acta Palaeontologica Polonica, v. 57, p. 205-224.

Zhuravlev, A.Yu., Wood, R.A., and Penny, A.M., 2015, Ediacaran skeletal metazoan interpreted as a lophophorate: Proceedings of the Royal Society B, v. 282. 20151860, p. 1-10. https://doi.org/10.1098/rspb.2015.1860.

Accepted: 22 November 2020 